Simone Milani Brandão

\title{
ANÁLISE DA BIOCOMPATIBILIDADE DE CONES DE BIOVIDRO E BIOVITROCERÂMICO EM CAVIDADE EVISCERADA DE COELHO
}

Orientadora: Prof ${ }^{\mathrm{a}}$. Dra Silvana A. Schellini

Botucatu

2010 
Simone Milani Brandão

\section{ANÁLISE DA BIOCOMPATIBILIDADE DE CONES DE BIOVIDRO E BIOVITROCERÂMICO EM CAVIDADE} EVISCERADA DE COELHO

Dissertação apresentada à Faculdade de Medicina, Universidade Estadual Paulista "Julio de Mesquita Filho", Campus de Botucat, para obtenção do título de Mestre em Bases Gerais da Cirurgia

Orientadora: Prof ${ }^{\mathrm{a}}$. Dra Silvana A. Schellini

Botucatu

2010 
FICHA CATALOGRÁFICA ELABORADA PELA SEÇÃO TÉCNICA DE AQUISIÇÃO E TRATAMENTO DA INFORMAÇÃO

DIVISÃO TÉCNICA DE BIBLIOTECA E DOCUMENTAÇÃO - CAMPUS DE BOTUCATU - UNESP BIBLIOTECÁRIA RESPONSÁVEL: Selma Maria de Jesus

Brandão, Simone Milani.

Análise da biocompatibilidade de cones de biovidro e biovitrocerâmico em cavidade eviscerada de coelho / Simone Milani Brandão. - Botucatu, 2010.

Dissertação (mestrado) - Faculdade de Medicina de Botucatu, Universidade Estadual Paulista, 2010

Orientadora: Silvana A. Schellini

Assunto CAPES: 40101177

1. Olhos - Cirurgia - Estudos experimentais 2. Biocompatibilidade 3. Biovidro

Palavras-chave: Biomaterial; Biocompatibilidade; Biovitrocerâmico; Cavidade oftálmica; Cone; Evisceração 


\section{DEDICATÓRIA}

Dedico aos meus pais Dorival e Jaciara Milani que sempre me apoiaram e acreditaram em mim. Os dois sempre foram um exemplo de vida e inspiração para querer atuar na área de ensino e pesquisa, por isso a conquista também é deles.

Ao Gustavo Brandão, amor da minha vida, que me levou ao mestrado em Botucatu e sempre esteve ao meu lado, me apoiando, me incentivando e compreendendo todos os momentos desta jornada.

Aos meus irmãos Maurício e Francine Milani pelo amor e carinho sempre dispensados. Agradeço também a troca de experiências que tivemos nestes anos, mesmo a distância, sempre ajudando no meu crescimento.

À minha Orientadora Dra Silvana Artioli Schellini que acreditou em mim e me ensinou muito, mas não só medicina, mas sobre a vida - é um exemplo de mulher, professora e médica. 


\section{AGRADECIMENTOS}

A Deus por tudo que conquistei e o que sou hoje.

À minha mãe que me ajudou muito, me acompanhando muitas vezes nas longas viagens a Botucatu e também trabalhando ativamente para tornar possível o experimento. Agradeço muito por não ter medido esforços durante toda a vida e neste momento também.

À Flávia por todo tempo dedicado a mim e a este experimento. Muito obrigada.

À FAPESP pela concessão de Auxílio à Pesquisa - Processo:2008/08058-0.

Ao Professor Dr. Carlos Roberto Padovani pelo auxílio na avaliação estatística do experimento.

Ao Professor Dr. Edgar Zanoto que me atendeu e norteou para que esta pesquisa fosse possível.

Ao Professor Oscar Peitl que tornou possível o experimento com a confecção das próteses estudadas e a atenção dispendida durante todo este tempo.

Aos funcionários da Cirurgia experimental, Marta e Carlos, pelo tempo dedicado a minha pesquisa e o cuidado no manejo do experimento. 
Aos funcionários dos Laboratórios Experimentais Florian e Vitor que confeccionaram as lâminas de histologia e me ajudaram a tomar decisões importantes para o estudo.

À funcionária Mara que me ajudou na preparação do sangue para análise dos exames bioquímicos.

À Professora Regina Kiomi Takahira da Veterinária e seus funcionários que fizeram os exames bioquímicos.

Ao Professor Dr. Luiz Carlos Vulcano, Diretor da Faculdade de Medicina Veterinária e Zootecnia da UNESP que disponibilizou a Tomografia Computadorizada do seu serviço e me ensinou sobre o exame.

Ao funcionário Heraldo da Tomografia pelo maravilhoso trabalho com as imagens e a paciência comigo e os meus coelhos.

À Professora Vânia Mari de Vascncelos Machado da Veterinária pela atenção disponibilizada nos dias dos exames.

Aos residentes da Patologia Veterinária pelo atendimento a um dos meus coelhos: obrigada pela atenção e os cuidados.

Ao Silvinho que fez as maravilhosas fotografias, durante todo o experimento, que constam nesta dissertação. 
Às enfermeiras Márcia Tonin e Susy, responsáveis pela esterilização do material do estudo.

Ao Professor José Carlos Georgete que confiou em mim e me deixou a vontade em seu laboratório para análise das imagens.

À Professora Elenize Jamas Pereira e a Fernanda pela ajuda no exame morfométrico.

À Professora Noemi Sousa Rocha pelos ensinamentos sobre Patologia.

À Professora Claúdia Helen Pellizzon pela sua contribuição na parte histológica.

Ao Nivalde Basso, funcionário do Instituto de Biociências pelo auxílio na parte de Microscopia Eletrônica de Varredura para uso neste trabalho.

À funcionária Claudete, funcionária do Instituto de Biociências, pela confecção do material para análise na Microscopia Eletrônica Varredura.

Ao Pós Graduando Ronaldo pela paciência e os ensinamentos para a leitura do material na Microscopia Eletrônica de Varredura.

À professora Daniela, chefe do Laboratório de Microscopia Eletrônica, pela ajuda na leitura do material.

À Funcionária Niva do Serviço de Biblioteca do Campus de Botucatu, pela ajuda no levantamento das bibliografias e a Selma, pela confecção da ficha catalográfica. 
Aos funcionários da Pós Graduação: Regina, Natanael, Janete e Andrea pelo excelente trabalho na orientação dos alunos.

À funcionária Simone, da Cirurgia e Ortopedia, pelas orientações recebidas.

Ao Residente de Oftalmologia Emerson Hashimoto que me ajudou prontamente toda vez que o solicitei, sem medir esforços para ajudar.

À Amanda Dias Moraes, aluna de iniciação científica e bolsista da FAPESP neste projeto.

À Maria Tereza Fiorindo, chefe de Benefício do INSS, que compreendeu a necessidade do meu mestrado e não mediu esforços para possibilitar que isto fosse possível.

Aos meus colegas de trabalho, Peritos Médicos do INSS, pela compreensão na minha ausência.

Aos meus chefes Dr. José Henrique Scabello e Dr. Nelson Gonçalves da Silva pelo apoio durante estes anos de estudo.

À Blaramis, chefe do Centro Municipal de Especialidades, que possibilitou minha ausência em alguns dias para poder realizar esta pesquisa.

À Poliana que, na minha ausência, cuidou da minha família com carinho e dedicação. 


\section{RESUMO}

Introdução: A reposição do volume perdido nas cavidades enucleadas e evisceradas é feita há muitos anos. O vidro foi o primeiro material utilizado para este fim, seguido por uma série de outros, sem que nenhum deles possa ser considerado como o material ideal. Mais recentemente, o vidro ou melhor, o biovidro, voltou ao cenário das reconstruções em outras áreas da Medicina, levantando-se a hipótese do uso destes em cavidade anoftálmica. Objetivo: avaliar experimentalmente a biocompatibilidade de cones de biovidro, biovitrocerâmico I e biovitrocerâmico II em cavidades evisceradas de coelhos. Método: foram utilizados 51 coelhos albinos, espécie Orictolagus cuniculus, submetidos a cirurgia de evisceração do olho direito, seguida da inclusão de cones na cavidade escleral. Os animais foram divididos em três grupos (G) que diferiram pelo tipo de biomaterial de que eram feitos os cones: cones de biovidro (GA), cones de biovitrocerâmico I (GB) e cones de biovitrocerâmico II (GC). Os animais foram sacrificados em três momentos (M) experimentais: sete (M1), 90 (M2) e 180 (M3) dias após a colocação dos cones na cavidade eviscerada. Os parâmetros avaliados foram: peso no início e ao final do período experimental; exame clínico diário; exames bioquímicos (TGO, TGP, CPK, FA, LDH, Uréia e Creatinina) imediatamente antes do procedimento cirúrgico e nos momentos de sacrifício; avaliação histológica do conteúdo orbitário e exame morfométrico da pseudocápsula e celularidade formada ao redor dos cones nos momentos de sacrifício; estudo tomográfico da órbita 45 dias após a evisceração e colocação dos cones; e microscopia eletrônica de varredura, realizada em seis coelhos no M3. Resultados: o exame clínico e os exames bioquímicos dos animais mostraram que os animais mantiveram-se saudáveis durante o experimento. Houve boa integração dos cones com os tecidos do hospedeiro em todos os grupos e em todos os 
momentos experimentais, não tendo ocorrido extrusão em nenhum dos animais. Histologicamente observou-se a formação de pseudocápsula ao redor dos cones, composta por reação fibrovascular, neovasos, poucas hemácias e células inflamatórias. O exame morfométrico mostrou que a reação inflamatória foi mais intensa no M1, diminuindo em direção ao M3, sendo menos intensa nos coelhos que receberam cones de biovidro (GA) que nos demais grupos de estudo. O exame tomográfico mostrou que os cones não migraram e não induziram alterações inflamatórias para a cavidade orbitária. O exame de microscopia eletrônica de varredura confirmou que o biovidro induz menor reação inflamatória tecidual. Conclusões: os cones de biovidro e biovitrocerâmico I e II podem ser úteis para a reparação da cavidade anoftálmica. Os cones de biovidro mostraram-se superiores aos compostos por biovitrocerâmico I e II, devido ao fato de provocarem menor reação inflamatória tecidual.

Palavras-chave: coelho, cavidade anoftálmica, biovidro, biovitrocerâmico, cone, biocompatibilidade, evisceração. 


\section{ABSTRACT}

Biocompatibility analisys of Bioglass and bioglassceramic cone in rabbit eviscerated cavity

Purpose: Replacement of lost volume in eviscerated and enucleated cavities has been performed for many years. Glass was the first material for this purpose, followed by a number of others, although none of them could be considered an ideal one. Recently, bioglass made its return at the reconstruction scenery, bringing up the hypothesis of its use in anophthalmic cavity. Objective: to evaluate bioglass, bioglassceramic and bioglassceramic II biocompatibility in rabbit's eviscerated cavities. Methods: 51 rabbitis were used, species Orictolagus cuniculus, all submitted to right eye evisceration surgery, followed by the inclusion of protheses in the escleral cavity. Those animals were gathered in 3 groups (G), distinguished through the type of material used to manufacture the cones: bioglass (GA), bioglassceramic (GB) and bioglassceramic II (GC). The animals were sacrificed at three distinctive experimental moments (M): 7 (M1), 90 (M2) and 180 (M3) days after the placement of cones in eviscerated cavities. The parameters evaluated were: daily clinical exam; biochemical exam (AST, ALT, CK, AP, HDL, urea and creatinine) before surgery and sacrifice; histological analysis; morphometric evaluation; ocular tomography 45 days after surgery; and scanning electron microscopy evaluation in six rabbits in M3. Results: Clinical and biochemical examination led to the conclusion that the animals stayed healthy during the experiment. There was good cone integration with the host tissue in every group and throughout every experimental moment, having occurred extrusion in none of the animals. Histologically, it was observed pseudocapsule formation around the cones, composed of fibrovascular reaction, neovases, low amount of erythrocyte and inflammatory cells. 
Morphometric evaluation showed that the inflammatory reaction was higher at M1, getting progressively lower while getting at M3, being the lowest in rabbits which received bioglass cones (GA) than at any other groups. Tomographic evaluation showed that the cones did not migrate and did not induce inflammatory alterations at the ocular cavity. Scanning electron microscopy evaluation confirmed that bioglass induce the lowest inflammatory tissue reaction. Conclusion: bioglass and bioglassceramic I and II cones can be useful to repair anophthalmic cavity. Bioglass cones showed itself superior to those composed by bioglassceramic I and II due to the fact they cause lower inflammatory tissue reaction.

Key words: rabbit, anophthalmic cavity, bioglass, bioglassceramic, cone, biocompatibility, evisceration. 


\section{CONTEÚDO}

Página

RESUMO 9

$\begin{array}{ll}\text { ABSTRACT } & 11\end{array}$

01 INTRODUÇÃO 25

1. Volume orbitário e a reparação após enucleação ou evisceração 26

2. Definição de biomateriais e biocompatibilidade 33

3. Histórico do biovidro 33

4. O uso do biovidro em cavidade anoftálmica no Brasil 37

$\begin{array}{ll}\text { 5. Justificativa do estudo } & 37\end{array}$

02 OBJETIVOS 38

03 MATERIAL E MÉTODO 39

1. Aprovação pelo Comitê de Ética $\quad 39$

2. Animais utilizados 39

3. Delineamento experimental: grupos e momentos experimentais 39

4. Variáveis estudadas $\quad 41$

5. Sequência dos tempos experimentais 43

6. Metodologia utilizada na produção dos cones 44

7. Técnica cirúrgica empregada para a colocação do cone na cavidade 49 eviscerada e detalhamento da sequência experimental

8. Método de coleta dos exames bioquímicos 54

9. Preparo para análise histológica e detalhamento do exame morfométrico 56

10. Metodologia utilizada para a realização dos exames de Tomografia 61 computadorizada

11. Microscopia Eletrônica de Varredura 63

12. Manutenção dos animais $\quad 67$ 
13. Sacrifício dos animais 68

14. Avaliação Estatística $\quad 69$

04 RESULTADOS $\quad 71$

1. Avaliação clínica dos animais dos diversos grupos experimentais: 71

1.1. Avaliação da região órbito-palpebral 71

1.2. Evolução clínica sistêmica 72

1.3. Peso dos animais $\quad 74$

2. Exames Bioquímicos $\quad 75$

4. Avaliação Histológica

4.1 - Observações Histológicas feitas em M1 82

4.1.1. Grupo A 82

4.1.2. Grupo B 82

4.1.3. Grupo C

4.2. Observações Histológicas feitas em M2 85

4.2.1. Grupo A

4.2.2. Grupo B 85

4.2.3. Grupo C 85

4.3. Observações Histológicas feitas em M3 87

$\begin{array}{ll}\text { 4.3.1. Grupo A } & 87\end{array}$

$\begin{array}{ll}\text { 4.3.2. Grupo B } & 87\end{array}$

$\begin{array}{ll}\text { 4.3.3. Grupo C } & 87\end{array}$ 
4.4. Resultados do exame morfométrico

88

4.4.1. Avaliação da espessura da pseudocápsula

88

4.4.2. Avaliação da celularidade existente na 90 pseudocápsula

4.4.3. Avaliação do colágeno

4.5. Avaliação Tomográfica

4.5.1. Observações Tomográficas feitas no Grupo A

4.5.2. Observações Tomográficas feitas no Grupo B

4.5.3. Observações Tomográficas feitas no Grupo C

4.6. Avaliação dos cones ao Microscópio Eletrônico de Varredura

97

4.6.1. Observações Ultra-estruturais com

98

Microscopia Eletrônica de Varredura, feitas no Grupo A

4.6.2. Observações Ultra-estruturais com

100

Microscopia Eletrônica de Varredura, feitas no Grupo B

102

4.6.3 Observações Ultra-estruturais com

Microscopia Eletrônica de Varredura, feitas no Grupo C

\section{DISCUSSÃO}

1. Escolha do tema e modelo experimental

2. Quanto ao desenvolvimento dos cones para o estudo

3. Avaliação clínica dos animais e a biocompatibilidade

Os exames bioquímicos

Avaliação da resposta cicatricial ao redor dos cones

Análise quantitativa da espessura da pseudocápsula e da celularidade nos implantes de biovidro, biovitrocerâmico I e biovitrocerâmico II

Análise do colágeno nos cones de biovidro, biovitrocerâmico I e biovitrocerâmico II 
5. Avaliação da Microscopia Eletrônica de Varredura 116

06 CONCLUSÃO 119

07 REFERÊNCIAS BIBLIOGRAFIAS 120

08 APÊNDICE 126

1. Comitê de ética 126 


\section{LISTA DE FIGURAS}

Figura 1 Imagem dos três tipos de cones, compostos pelos biomateriais utilizados: A) biovidro; B) biovitrocerâmico I; C) biovitrocerâmico II.

Figura 2 Vista lateral do cone de biovidro utilizado no presente experimento.

Figura 3 Sequência do procedimento cirúrgico de evisceração realizada nos coelhos, seguida da colocação dos cones dos diferentes biomateriais. A) Posicionamento do coelho em decúbito lateral esquerdo, de forma que o olho direito permanecesse voltado para cima; B) Instilação de colírio anestésico; C) Antissepsia usando PVPI; D) Paracentese com bisturi lâmina 11; E) Abertura córneo-escleral com tesoura tipo Westcott; F) Separação da córnea e esclera; G) Retirada da córnea; H) Evisceração com remoção das estruturas intraoculares; I) Limpeza da capa escleral usando cureta; J) Apresentação da capa escleral após remoção das estruturas intraoculares; K) Colocação do cone na cavidade; L) Sutura escleral com mersilene 6-0; M) Aspecto da sutura escleral completa; N) Sutura conjuntival com mersilene 6-0; O) Aspecto da finalização do procedimento P) Instilação de solução oftálmica de Gatifloxacino colírio ao final do experimento.

Figura 4 Demonstração da coleta de sangue da veia auricular do coelho para análises bioquímicas.

Figura 5 Figura contendo um cone esquemático, com a identificação das regiões padronizadas para análise na lâmina histológica.

Figura 6 Demonstração da região de análise da espessura da pseudocápsula, realizada na coloração de HE, em três locais (L1, L2 e L3) de cada uma das regiões apontas na figura 5,, usando a lupa e no aumento de $40 \mathrm{X}$.

Figura 7 Fotografia da estação de comando do Tomógrafo da Faculdade de Medicina Veterinária e Zootecnia da Universidade Estadual Paulista- UNESP Campus de Botucatu.

Figura 8 Coelho posicionado para exame de Tomografia Computadorizada, Faculdade de Medicina Veterinária e 
Zootecnia da Universidade Estadual Paulista- UNESP Campus de Botucatu.

Figura 9 Animal anestesiado e posicionado ventralmente com o crânio apoiado e elevado para a realização da Tomografia Computadorizada.

Figura 10 Esclera envolvendo o cone removidos da cavidade orbitária após o sacrifício do animal. Demonstração do método utilizado na partida do material de estudo ao meio com auxílio de uma lâmina diamantada ligada a um motor de 3.000 rotações por minuto, sob irrigação com soro fisiológico a $0,9 \%$.

Figura 11 Material de estudo partido ao meio, mostrando o cone firmemente aderido a esclera, imediatamente antes da fixação em glutaraldeído.

Figura 12 Imagens do exame de Microscopia de Varredura. A) Material colocado nos "stubs" dentro do Microscópio Eletrônico de Varredura sob vácuo. B) Imagem da superfície do cone com aumento de 37X. C) Idem com aumento de 120X. D) Idem com aumento de 450X.

Figura 13 Fotografia do Biotério de Manutenção dos animais utilizados no experimento, com detalhe dos coelhos acondicionados em gaiolas individuais.

Figura 14 Material retirado imediatamente após eutanásia, identificando-se a esclera envolvendo o cone de biomaterial estudado.

Figura 15 Aspecto da cavidade anoftálmica de coelho após sete dias (M1) de evisceração do olho direito. Observar a ausência de pelos na região adjacente a fenda palpebral e a escassez de sinais inflamatórios.

Figura 16 Cortes histológicos referentes a reação de reparação tecidual formada entre a esclera e os cones no M1 (seta). A) Biovidro. B) Biovitrocerâmico I. C) Biovitrocerâmico II. Em todos os cortes nota-se a pseudocápsula, formada por fibroblastos, hemácias e células inflamatórias( HE 40X ).

Figura 17 Cortes histológicos referentes a reparação tecidual formada entre a esclera e os cones no M2. A) Biovidro. B) Biovitrocerâmico I. C) Biovitrocerâmico II. Nota-se a pseudocápsula menos espessa, principalmente no grupo A (HE 40X). 
Figura 18 Cortes histológicos referentes a reparação tecidual entre a esclera dos coelhos e os cones no momento 3 (M3).. A) Biovidro. B) Presença do biomaterial (seta) envolto por tecido reparativo do hospedeiro C) Biovitrocerâmico. D) Biovitrocerâmico II. Nota-se pseudocápsula formada por fibroblastos, ausência de edema e pequena reação inflamatória (HE 40X).

Figura 19 Corte histológico referente a reparação tecidual formada entre a esclera e os cones no Grupo A, em M1. As fibras colágenas coradas em vermelho; os miócitos em amarelo; e os espaços em branco. Picrosirius Red (PR 40X).

Figura 20 Tomografia computadorizada realizada nos coelhos em posição ventral com o crânio apoiado e elevado. Os cortes foram feitos de $1 \mathrm{x} 1 \mathrm{~mm}$ (1mm de espessura por $1 \mathrm{~mm}$ de intervalo de reconstrução) e as imagens avaliadas em janela óssea e de partes moles, com o FOV ( Field Of ViewCampo de Visão) de $11 \mathrm{~cm}$. Observar imagem do cone na cavidade orbitária (seta).

Figura 21 Cortes tomográficos do crânio do coelho na posição transversal, onde se observa na órbita direita, o cone de biovidro e, na esquerda, o bulbo ocular.

Figura 22 Cortes tomográficos do crânio do coelho na posição 96 transversal, onde se observa na órbita direita, o cone de biovitrocerâmico I e, na esquerda, o bulbo ocular.

Figura 23 Cortes tomográficos do crânio do coelho na posição transversal, onde se observa na órbita direita, o cone de biovitrocerâmico II e, na esquerda, o bulbo ocular.

Figura 24 Imagem referente a animal do grupo A em M3. Fratura da camada mais externa do cone, separando uma camada mais densa do biomaterial. Na região mais interna o biovidro apresenta microfraturas (MEV 450X).

Figura 25 Imagem referente a animal do grupo A em M3. Fratura retilínea na superfície de contato do biovidro da esclera (seta). Efeito de corte induzido para o preparo do material, o biovidro forma pequenas placas que se desprendem. Esclera (E)(MEV 37X). 
Figura 26 Imagem referente a animal do grupo B em M3. Presença da

101 linha de fratura na camada superficial do material, separando o biomaterial em duas camadas distintas(MEV 38X).

Figura 27 Imagem referente a animal do grupo B em M3. Presença das 102 camadas superficial e profunda, com inúmeras "rachaduras" de formato de figuras geométricas (seta) (MEV 549X).

Figura 28 Imagem referente a animal do grupo C em M3. Superfície 103 entre o biomaterial e o hospedeiro com grande quantidade de fibrose, não permitindo a observação do biomaterial, com poucas células inflamatórias e poucas hemácias (MEV 120X).

Figura 29 Imagem referente a animal do grupo C em M3. Presença de capa de fibrose é vista como uma superfície algodonosa que envolve todo o cone e não permite visibilizá-lo (MEV 469X).

Figura 30 Primeiras próteses de vidro com formatos anteriores 107 diferentes devido a tensão de superfície.

Figura 31 Molde de grafite de alta precisão, considerados a melhor opção para a obtenção de cones de mesmo padrão de formato e tamanho.

Figura 32 Formato da prótese de biovidro antes e após a aplicação do 108 vácuo em sua confecção.

Figura 33 Prótese cônica de biovidro após o desbaste/lixamento.

Figura 34 Imagem da Microscopia Eletrônica de Varredura. A) biomaterial. B) integração. C) material do hospedeiro. 


\section{LISTA DE TABELAS}

Tabela 1 Composição Química do Biovidro e do Biosilicato

Tabela 2 Tratamento térmico empregado no Laboratório de Materiais Vítreos - LAMAV, pertencente a Universidade Federal de São Carlos, para cristalizar o biovitrocerâmico nos processos de nucleação e cristalização.

Tabela 3 Média e desvio padrão do peso inicial (em gramas) dos coelhos, segundo grupo experimental.

Tabela 4 Média e desvio padrão do peso de coelhos segundo grupo e momento de sacrifício.

Tabela 5 Média e desvio padrão das dosagens bioquímicas da Uréia e Creatinina de coelhos submetidos a evisceração do olho direito e colocação de cones na cavidade anoftálmica, segundo grupo e momento de avaliação.

Tabela 6 Mediana e valores máximo e mínimo das dosagens bioquímicas da TGO de coelhos submetidos a evisceração do olho direito e colocação de cones na cavidade anoftálmica, segundo grupo e momento de avaliação.

Tabela 7 Mediana e valores máximo e mínimo das dosagens bioquímicas da TGP de coelhos submetidos a evisceração do olho direito e colocação de cones na cavidade anoftálmica, segundo grupo e momento de avaliação.

Tabela 8 Mediana e valores máximo e mínimo das dosagens bioquímicas da fosfatase alcalina de coelhos submetidos a evisceração do olho direito e colocação de cones na cavidade anoftálmica, segundo grupo e momento de avaliação.

Tabela 9 Mediana e valores máximo e mínimo das dosagens bioquímicas da LDH de coelhos submetidos a evisceração do olho direito e colocação de cones na cavidade anoftálmica, segundo grupo e momento de avaliação. 
Tabela 10 Mediana e valores máximo e mínimo das dosagens bioquímicas da CPK de coelhos submetidos a evisceração do olho direito e colocação de cones na cavidade anoftálmica, segundo grupo e momento de avaliação.

Tabela 11 Mediana e valores máximo e mínimo referentes a espessura da pseudocápsula formada entre a esclera e os cones, em cavidades evisceradas de coelhos, segundo grupo, momento de avaliação e região onde foi realizada a observação.

Tabela 12 Mediana e valores máximo e mínimo referentes a celularidade observada nos tecidos regenerativos formados entre a esclera e os cones, em cavidades evisceradas de coelhos, segundo grupo e momento de avaliação.

Tabela 13 Porcentagem de colágeno avaliada no exame de lâminas coradas por Picrosirius Red segundo implante e momento, e seus valores máximo e mínimo 


\section{LISTA DE GRÁFICOS}

Gráfico 1 Mediana, valores máximo e mínimo, da quantidade de 92 colágeno encontrado na interface entre a esclera e os cones, segundo grupo e momentos de estudo. 


\section{LISTA DE FLUXOGRAMA}

Fluxograma 1 Apresentação do processo de obtenção dos implantes de 48 biovidro e biovitrocerâmico. 


\section{1 - INTRODUÇÃO}

Algumas doenças oculares, como o glaucoma, o trauma e a endoftalmite podem cursar com perda da função visual, causando sofrimento, desfiguramento da aparência, com reflexos psicológicos desfavoráveis para o portador. Muitas vezes há necessidade de intervenção cirúrgica para minimizar a dor ou para restaurar a aparência do indivíduo, possibilitando ao mesmo o retorno ao mercado de trabalho e a vida normal.

Muitas vezes há necessidade de se remover o olho como um todo (enucleação) ou o seu conteúdo (evisceração), a fim de reduzir a dor (decorrente de edema de córnea, glaucoma absoluto), para conservar a saúde geral do indivíduo (no caso dos tumores oculares), ou por razões estéticas (leucoma, phithisis bulbi).

A face é a “janela” para o mundo e, sendo assim, o olho é foco de atenção e identificação do ser humano. Alterações oculares são marcantes e podem acarretar graves prejuízos para a estética facial. Especial atenção deve ser dada para a perda do volume orbitário, pois a contração e a de formação dos tecidos contidos na cavidade orbitária são os maiores problemas estéticos enfrentados pelo indivíduo que apresenta uma afecção que necessite de remoção do olho ou de seu conteúdo.

Tanto a enucleação, quanto a evisceração, reduzem o conteúdo da cavidade orbitária, havendo necessidade de reposição de volume para que se tenha aspecto estético aceitável (MULES, 1990; MIGLIORI, 2002; PERRY et al., 2009). A enucleação provoca perda mais acentuada de volume para a órbita, uma vez que o trauma para as estruturas orbitais é maior (MIGLIORI, 2002). Entretanto, também com a evisceração há perda de volume, com reflexos negativos para a aparência da face (SHIRATORI et al., 2005). 
A reparação após a perda de volume orbitário deve ser realizada, buscandose como resultado final a simetria com o lado contralateral. Ou seja, a devolução do volume orbitário tem como objetivo principal evitar o prejuízo estético para o paciente (SU; YEN, 2004).

A técnica cirúrgica escolhida, a experiência do cirurgião, as condições de assepsia e o material adequado a ser implantado são muito importantes para prevenir a complicação mais temida neste tipo de cirurgia: a extrusão do implante (RODRIGUES et al., 1997).

Quando a devolução de volume é primária, ou seja, é feita no mesmo ato cirúrgico realizado para a enucleação ou evisceração ocular, 90\% das pessoas tratadas apresentam bons resultados (HABAL, 1987).

\section{Volume orbitário e a reparação após enucleação ou evisceração}

O olho humano apresenta formato esferóide, com volume de $7 \pm 2 \mathrm{~cm}^{3}$ e diâmetro de $24 \mathrm{~mm}$. Ele se encontra dentro da cavidade orbitária que possui volume total de $32 \pm 2 \mathrm{~cm}^{3}$, composto pelo volume do bulbo ocular e pelos músculos extrínsecos, vasos sanguíneos, nervos e gordura (HABAL, 1987).

Quando da necessidade de remoção do bulbo ocular ou de seu conteúdo, o volume perdido pode ser devolvido para a cavidade orbitária de várias formas, tais como usando materiais autólogos, heterólogos ou aloplásticos. Em linguagem corrente, os materiais aloplásticos utilizados para devolver o volume orbitário, são conhecidos como implantes, termo que segundo Pigossi e colaboradores (1971) não estaria correto, devido ao fato de que implantes são transplantes de células que não possuem viabilidade 
vital; ou seja, o melhor termo para definir o objeto utilizado para a reposição de volume em cavidade anoftálmica seria inclusão (PIGOSSI et al., 1971). De qualquer forma, utilizar a reposição de volume no tratamento da cavidade anoftálmica, evita a contração dos tecidos orbitários e possibilita que posteriormente sejam adaptadas próteses externas, com melhoria da estética facial (KARESH, 1998).

Os tecidos autólogos que podem ser utilizados para reposição de volume na cavidade orbitária seriam: cartilagem, osso, fáscia lata, gordura (GOUGELMAN, 1976). Estes tecidos, por serem obtidos do próprio hospedeiro, não necessitam de triagem especial; porém necessitam de um segundo sítio cirúrgico. Já os materiais heterólogos, dispensam a necessidade de um segundo sítio operatório; entretanto, há que se prever a utilização de métodos de triagem de doadores, meios de conservação ou preservação, acondicionamento e transporte adequados (BEAVER et al., 1996).

Os materiais aloplásticos são os mais utilizados para a reparação da cavidade anoftálmica, devido a sua fácil obtenção, ausência de risco de transmissão de doenças, cirurgia que necessita de apenas um procedimento operatório, dispensando a preservação ou a conservação dos implantes.

A necessidade de devolver volume para cavidades anoftálmicas é reconhecida há séculos e a procura do melhor meio para se conseguir este intento é estudada há muitos anos.

Os primeiros implantes utilizados datam do ano de 1885, quando Mules desenvolveu esferas de vidro que foram implantadas após eviscerações e, em seguida, após as enucleações (TONKELAAR et al., 1991). O vidro foi o principal material utilizado até os anos 40 do Século passado (PERRY, 1990), época em que a fábrica de esferas de vidro foi destruída na Grande Guerra. A falta desta fábrica fez com que os 
profissionais passassem a usar esferas confeccionadas usando materiais autólogos, como as bolas de ossos e cartilagem (SU; YEN, 2004). Também novos materiais sintéticos começaram a surgir, como o polimetilmetacrilato (PMMA) e o silicone, também chamadas de esferas não integradas.

Até 1989, os implantes mais usados no mundo todo eram os implantes não integrados, em especial os fabricados usando o PMMA ou o silicone. Foi nesta época que Perry sugeriu o uso dos implantes porosos, confeccionados de hidroxiapatita coralina ou hidroxiapatita natural (SIRES et al., 1998), cujo principal ponto de diferença com os implantes não integrados é o fato de que os integrados possuem poros que permitem o crescimento fibrovascular no seu interior, com forte apelo para a melhora da mobilidade da prótese externa (LIN et al., 2002), já que o implante que recebe a colonização dos tecidos do hospedeiro poderia ser perfurado, com acoplagem de parafuso tipo macho/fêmea que fixa a inclusão presente na cavidade orbitária com a prótese externa, permitindo a transmissão dos movimentos dos músculos extrínsecos do olho para o implante (PERRY, 1990).

Vale à pena ressaltar que o implante de hidroxiapatita natural não foi o primeiro implante integrado existente na literatura, já que por volta de 1940 haviam sido sugeridos implantes feitos de um material metálico inerte (o ouro), com o formato de esfera, com superfície do tipo de uma "peneira”, que permitia a “integração” com o hospedeiro, na medida em que o tecido do receptor era capaz de crescer para o seu interior, permeando os "poros” da esfera. Este implante não prosperou, em decorrência das grandes complicações observadas, tais como as exposições e extrusões em decorrência da abertura da tênue membrana conjuntival (TONKELAAR et al., 1991). 
Portanto, na década de 80 houve o retorno a este conceito, reiniciando-se o uso de esferas integradas conforme proposto por Perry, usando a hidroxiapatita natural, derivada do coral marinho, que passa por um processo de sinterização. As esferas fabricadas por este processo possuem custo elevado, principalmente por serem derivadas da natureza, justificando-se que estas são derivadas de fonte que pode se exaurir (PERRY, 1990; PERRY et al., 2002).

Seguindo o mesmo raciocínio de que as esferas integradas teriam melhor mobilidade, surgem, em seguida, várias outras hidroxiapatitas, agora fabricadas de material sintético, todas elas tendo por base em sua fórmula química o carbonato de cálcio (JORDAN et al., 2000a; SCHELLINI et al., 2003).

Muitas discussões aconteceram a respeito das hidroxiapatitas sintéticas, relacionadas com o estado de pureza do material (JORDAN et al., 2000a), com a possibilidade de se ter a absorção sistêmica do material implantado, com redução do volume que se pretendia devolver para a cavidade orbitária (RANZANI et al., 1997), ficando este último ponto como a principal de todas as queixas que existiram com relação a este material.

A procura por novos materiais sintéticos para reposição do volume orbitário continuou, chegando-se ao polietileno poroso, um material inerte e que permanece no local de implantação (GOLDBERG et al., 1994; KARESH, 1998; HSU et al., 2000; JORDAN et al., 2000a; PERRY et al., 2002; JORDAN et al., 2002; ANDERSON et al., 2002; SCHELLINI et al., 2003; FERRAZ et al., 2006; CUSTER; TRINKAUS, 2007). Outra vantagem é o custo, muitas vezes menor que o das hidroxiapatitas naturais (SCHELLINI et al., 2003). Sua forma em gel foi pesquisada baseados na hipótese de que o contato do implante rígido com a prótese externa favoreceria a isquemia tecidual, 
levando a deiscência que pode resultar, em última análise, nas extrusões (SCHELLINI et al., 2008).

Os motivos que tem levado ao estudo de novos materiais são o risco de complicações, como as deiscências de sutura, as extrusões do implante e os processos inflamatórios exacerbados (KARESH, 1998; SU; YEN, 2004; FRANÇA et al., 2005; BRITO, 2008).

O risco de haver complicações relacionadas com o material utilizado e a técnica cirúrgica aplicada, como extrusão do implante, deiscência de suturas (RODRIGUES et al., 1997; GUPTA et al., 2001; KLAPPER et al., 2003; SCHELLINI et al., 2007), trauma mecânico da esclera e processos inflamatórios exacerbados (KARESH, 1998; SU; YEN, 2004), também são motivos que tem levado ao estudo de novos materiais (FRANÇA et al., 2005; BRITO, 2008).

Talvez o principal motivo para se continuar pesquisando novos materiais para reconstrução da cavidade anoftálmica esteja relacionado ao fato de que ainda não se encontrou o material considerado ideal para a reconstrução da cavidade anoftálmica.

Para os brasileiros, acresce-se a isso, a inexistência no mercado nacional das inovações que surgem no mercado internacional, ficando a população composta de indivíduos mais desassistidos, uma vez que os preços de importação são abusivos.

Nos Estados Unidos da América, entre os materiais aloplásticos, o mais utilizado atualmente, referido como o de melhor resultado cirúrgico para preenchimento de cavidades anoftálmicas e de boa integração tecidual, é o polietileno poroso de alta densidade, registrado como Medpor $^{\circledR}$ (Porex) (BLAYDON et al., 2003; SU; YEN, 2004). 
Apesar de se ter pesquisas brasileiras sobre a utilização de polietileno poroso americano em cavidades anoftálmicas de humanos (MOURA et al., 2007), pode-se afirmar que o alto custo das esferas da Porex limita o seu uso na prática clínica. Estes biomateriais, inicialmente tidos como inertes quando implantados no organismo, qualquer que seja o tipo de material utilizado, mesmo os biocompatíveis, desencadeiam reação inflamatória no hospedeiro, representada pela formação de cápsula ou pseudocápsula fibrosa envolvendo o implante (SCHELLINI et al., 2000).

Até o momento, nenhum estudo foi feito entre os oftalmologistas brasileiros que possa apontar qual é o material mais empregado na reparação da cavidade anoftálmica em território nacional. Entretanto, observações pessoais permitem dizer que os cirurgiões brasileiros ainda empregam preferentemente para a reparação da cavidade anoftálmica, o implante de polimetilmetacrilato.

Existem outros materiais que estão sendo explorados para uso em cavidade anoftálmica, dentre eles está o biovidro. Este material começou a ser utilizado a partir de 1969. Entretanto, somente após a criação da terceira geração deste biomaterial, o que ocorreu no ano de 1985 com a patente do implante de Bioglass ${ }^{\circledR}$ - é que surgiram vários estudos sobre a utilização do biovidro em diversas áreas da Medicina (OONISHI et al., 1997; AMATO et al., 2003; HENCH, 2006).

No estudo realizado por Amato e colaboradores (2003), o Bioglass ${ }^{\circledR}$ foi utilizado para aumentar o volume de órbitas enoftálmicas, recobrindo defeitos em assoalho orbitário de coelhos, demonstrando-se haver biocompatibilidade, com pouca reação inflamatória, sem infecção, sem exposição do implante, ausência de problemas para o bulbo ocular, estimulação do crescimento ósseo e capacidade de aumento do volume orbitário. 
Em se tratando de biomaterial, um novo conceito é a associação de substâncias que possam ter, entre si, uma interação positiva. Assim, o Bioglass ${ }^{\circledR}$ (biovidro) foi testado também em associação com o Medpor ${ }^{\circledR}$ (polietileno poroso), mostrando ainda melhores resultados (AMATO et al., 2003).

Seguindo este mesmo conceito, surge o desenvolvimento de novos materiais cerâmicos com diferentes tratamentos térmicos, demonstrando eficiência e melhora da biointegração. Dentre eles, o biovitrocerâmico (Biossilicato ${ }^{\circledR}$ ) (PEITL et al., 2001; CHEN et al., 2006) que já foi usado em próteses para substituição dos ossículos do ouvido (MASSUDA; OLIVEIRA, 2007) e para preenchimento dos alvéolos dentários de cães (RORIZ; PANZERI, 2006; TIRAPELLI; PANZERI, 2007), com bons resultados in vivo. O biovitrocerâmico também foi testado e aprovado para uso como matriz polimérica para reconstrução do complexo zigomático orbitário de humanos (TURREN et al., 2008).

Existe ainda, pesquisas com biocerâmicos em cavidades evisceradas, enucleadas ou em implantes secundários, na forma de um óxido de alumínio $\left(\mathrm{Al}_{2} \mathrm{O}_{3}\right)$, mostrando-se uma alternativa aos implantes orbitais porosos, aprovado pelo FDA (Food and Drug Administration) para uso nos Estados Unidos da América no ano 2000, principalmente pelo menor custo, quando comparado ao Bioglass e Medpor (JORDAN et al., 2000b).

Os estudos com biovitrocerâmico vem mostrando bons resultados em animais e humanos (MOURA et al., 2007). A possibilidade de desenvolvimento de implantes orbitários a partir deste material, comparados com próteses compostas por biovidro, permitirá a avaliação da biocompatibilidade destes diferentes biomateriais, com possível identificação de viabilidade de uso nas cavidades anoftálmicas. 


\section{Definição de biomateriais e biocompatibilidade}

Os chamados biomateriais são materiais usados para entrar em contato com tecidos vivos com objetivo de recompor uma parte danificada ou auxiliar na recuperação do tecido do organismo. Estes quando sintéticos, podem ser divididos em cerâmicos (Biovidro, biovidrocerâmico), polímeros (substâncias compostas por cadeias longas de Carbono: polietileno e polimetilmetacrilato) e metálicos (aço inoxidável, titânio, ouro, prata) (FRATZL; BARTH, 2009).

A biocompatibilidade é a capacidade de um material de funcionar com resposta apropriada ao hospedeiro em uma aplicação específica. Esta ação deve-se ser contínua, ou seja, deve-se exercer ação para a qual foi programado por um período tão longo quanto necessário. Esta biocompatibilidade é dependente diretamente da composição e reações químicas do material e também do tipo de tecido e saúde do hospedeiro em que for implantado (FRANÇA, 2003).

\section{Histórico do biovidro}

Dados históricos a respeito das próteses utilizadas na reparação da cavidade anoftálmica podem ser obtidos da publicação de Tonkelaar e colaboradores, segundo a qual os primeiros implantes utilizados em cavidades anoftálmicas eram de vidro. A reposição de volume em cavidades anoftálmicas foi o principal assunto do Congresso Europeu de Oftalmologia, ocorrido no ano de 1900; entretanto, a fábrica de vidro utilizado na confecção dos implantes era situada na Alemanha, tendo sido destruída nas Grandes Guerras (TONKELAAR et al., 1991).

Passando por todos os desafios descritos anteriormente neste capítulo introdutório na procura do material ideal para reconstrução da cavidade anoftálmica, 
volta-se no meio do século XX novamente ao vidro como componente de biomateriais, o que ocorreu na Ohio State University (OSU), nos anos de 1957/1958, quando se estudou o material precursor do Bioglass ${ }^{\circledR}$, com os primeiros resultados publicados na American Ceramic Society, no ano de 1962 (TONKELAAR et al., 1991; HENCH, 2006).

A partir daí, vários estudos surgiram, visando encontrar a fórmula ideal do biomaterial que não fosse “rejeitado” pelo organismo humano. A fórmula mais próxima ao Bioglass ${ }^{\circledR}$ foi desenvolvida no ano de 1967, mas foi divulgada somente em 1969 $\left(\mathrm{Na}_{2} \mathrm{O}-\mathrm{CaO}-\mathrm{SiO}_{2}\right)$, tendo sido testada como implante em fêmur de ratos pelo Dr. Ted Greenlee (GREENLEE, Jr. et al., 1972).

Em 1976, o professor alemão Peter Gress usou o implante do Bioglass recoberto com alumina (óxido de alumínio- $\mathrm{Al}_{2} \mathrm{O}_{3}$ ) em ovelhas e os resultados mostraram que a superfície não era estável. Isso levou a busca de novas fórmulas que utilizassem o Bioglass ${ }^{\circledR}$ 45S5 em associação com outras substâncias químicas, como em 1977, quando se procedeu a adição de pequena quantidade de $\mathrm{K}_{2} \mathrm{O}$ e $\mathrm{MgO}$ aos implantes, utilizando modelos animais. Seu uso clínico foi limitado devido à instabilidade na fase de formação da cristalização do vitrocerâmico (TONKELAAR et al., 1991).

A modificação mais importante do biomaterial de vidro foi realizada pelo professor Yamamuro, da Universidade de Kuoto-Japão, que submeteu o biovidro a uma sinterização (transformar pó em peça rígida através de tratamento térmico) e a cristalização que, gerou a formação, na interface do Bioglass ${ }^{\circledR}$, da apatita (fosfato de cálcio) e do mineral wollastonita $\left(\mathrm{CaSiO}_{3}\right)$ o que, em estudos experimentais em animais, mostrou ser excelente para a aplicação ortopédica (3000 casos de prótese vertebral, 
1200 casos de laminectomia, 2000 de próteses da crista ilíaca) (YAMAMURO et al., 1990; HENCH, 2006).

Uma nova modificação na fórmula realizada pelos Professores Orjan Anderson e Kai Karlsson, foi testada e seu uso clínico para reparação cirúrgica de coluna e crânio foi um sucesso por vários anos (HENCH, 2006).

Em 1981, o Dr. June Wilson e alguns colegas realizaram o primeiro estudo in vitro e in vivo em tecidos conectivos, uma vez que, antes disso, o biovidro havia sido testado apenas como prótese para reparação óssea. Após aprovação do comitê de ética, deu-se a realização do primeiro trial clínico (HENCH, 2006).

Já com o nome de Bioglass ${ }^{\circledR}$, no ano de 1985 foi publicado nos Estados Unidos da América o primeiro trabalho realizado com esta fórmula registrada. O material foi utilizado para tratar a perda auditiva de condução, na orelha média, mostrando bons resultados na recuperação dos ossículos do ouvido e da membrana timpânica. Este biomaterial ficou conhecido como o Bioglass de primeira geração (HENCH, 2006).

A segunda geração do Bioglass ${ }^{\circledR}$ teve sua fórmula usada em Odontologia, no ano de 1988 (HENCH, 2006).

Após vários estudos experimentais, chegou-se a terceira geração do Bioglass ${ }^{\circledR}$, a qual proporcionou regeneração e reparação dos tecidos no local em que foi implantada, devido à ativação dos genes nos tecidos vivos. Os estudos foram realizados com várias aplicações clínicas, como na pele, no sistema vascular, na cartilagem auricular e também na reparação óssea. Nestes casos, o Bioglass ${ }^{\circledR}$ foi capaz de “estimular” a produção do tecido ósseo por meio da reparação pela osteoprodução e osteoestimulação, decorrente da ação direta nos osteoblastos (HENCH, 2006). 
O FDA liberou o uso do Bioglass ${ }^{\circledR}$ no ano de 1996, a ser utilizado na região alveolar de dentes extraídos, após a publicação que descreveu o potencial do biomaterial usado em periodontia, ocorrida no ano de 1987, que abordava estudo de Wilson $e$ colaboradores, da Universidade da Flórida. A partir deste trabalho e mais dois, publicados em 1992 e 1994, este material recebeu o nome de PerioGlass ${ }^{\circledR}$, material este que já possui período longo de observação, com 10 anos de resultados sem reações adversas (HENCH, 2006).

Diante do sucesso do PerioGlass ${ }^{\circledR}$, em 1999 seu uso em ortopedia trouxe o nome de NovaBone ${ }^{\circledR}$, demonstrando regeneração efetiva do osso com o uso do 45S5 Bioglass ${ }^{\circledR}$. Em 2005, foi publicado um estudo de bons resultados em humanos, com dois anos de acompanhamento clínico (TONKELAAR et al., 1991).

Mais recentemente, este tipo de biomaterial vem sendo estudado para tratamento de hipersensibilidade dentária (RORIZ; PANZERI, 2006; TIRAPELLI; PANZERI, 2007), em substituição dos ossículos do ouvido (MASSUDA; OLIVEIRA, 2007) e em reconstrução do complexo zigomático orbitário (TURREN et al., 2008).

A partir daí, estudos brasileiros sugeriram o tratamento cerâmico do biovidro, mostrando que a cristalização que sofre o material, gerando o biovitrocerâmico, faz decrescer o nível de bioatividade, tornando o material mais inerte ao organismo em que for implantado (PEITL et al., 2001; MOURA et al., 2007).

O presente estudo foi motivado pelo fato dos bons resultados obtidos por estes materiais, aliado a necessidade de se desenvolver um material que possa ser considerado ideal para o tratamento da cavidade anoftálmica. 


\section{O uso do biovidro em cavidade anoftálmica no Brasil}

O biovidro foi usado em coelhos, no campo da plástica ocular, na forma de compósitos, que são materiais formados por dois ou mais constituintes, com distintas composições, estruturas e propriedades, que estão separados por uma interface. Neste primeiro estudo no Brasil, o Biovidro foi associado com polietileno e usado como controle o Medpor® e Polipore em implantação do biomaterial em órbitas de coelhos. Os resultados do estudo demonstraram uma ótima biocompatibilidade, com os compósitos apresentando melhores resultados que os controles, o que foi deduzido a partir da observação de menor reação inflamatória justamente no grupo que recebeu os compósitos. Quanto à bioatividade, os compósitos de biovidro com polietileno apresentaram alta angiogênese, formação de uma pseudocápsula mais espessa e estrutura mais rica em colágeno (FRANÇA, 2003; FRANÇA et al., 2005).

\section{Justificativa para a realização do estudo}

Tendo em vista a aplicação do biovidro com bons resultados em estudos experimentais e clínicos, inclusive com o uso em cavidade anoftálmica de coelhos, e que materiais compostos de biovidro cristalizado podem ser úteis e necessitam de maiores estudos para nos dar esta definição, levando-se em conta que nenhum dos biomateriais existentes pode ser considerado ideal para uso em cavidade anoftálmica, justifica-se a realização do presente estudo. 


\section{2 - OBJETIVOS}

Objetivo geral: usando um modelo experimental, demonstrar se cones de biovidro ou biovitrocerâmico podem ser úteis para a reparação de cavidades anoftálmicas.

Objetivo específico: avaliar a biocompatibilidade de cones de biovidro e outros dois tipos de cones compostos por biovitrocerâmico (biovitrocerâmico I e biovitrocerâmico II), introduzidos em cavidades evisceradas de coelhos, estudando-se:

1. a resposta clínica dos animais após a colocação dos cones nas cavidades anoftálmicas;

2. a possível toxicidade sistêmica dos cones, avaliada por meio de exames bioquímicos que possam refletir o funcionamento de órgãos vitais dos animais de estudo;

3. a avaliação da resposta dos tecidos orbitários após a colocação dos cones na cavidade eviscerada, por meio de exame histológico e morfométrico;

4. a avaliação do posicionamento dos cones e a situação dos mesmos em relação aos tecidos vizinhos, por meio de exame tomográfico;

5. a avaliação da superfície de contato dos cones com o hospedeiro, por meio de microscopia eletrônica de varredura. 


\section{3 - MATERIAL E MÉTODO}

\section{Aprovação pelo Comitê de Ética}

Esse trabalho encontra-se de acordo com os princípios éticos utilizados na experimentação animal, adotados pelo Comitê de Ética da Faculdade de Medicina de Botucatu UNESP - São Paulo, para o uso de animais de experimentação, tendo sido aprovado para execução em 26 de junho de 2008 (protocolo número 682 - Apêndice 1).

\section{Animais utilizados}

O estudo foi cego, experimental e aleatorizado. Foram utilizados 51 coelhos da espécie Oryctolagus cuniculus, raça Norfolk (albino), sexo masculino, com idade entre três e seis meses. Os animais foram cedidos pelo Biotério Central da UNESP, localizado no Campus de Botucatu.

\section{Delineamento experimental: grupos e momentos experimentais}

Os animais foram divididos em três grupos experimentais, cada um deles composto por 17 coelhos. Os grupos diferiram entre si pelo tipo de biomaterial que foi utilizado: grupo A (GA) que recebeu cones de biovidro, com composição semelhante ao Bioglass ${ }^{\circledR}$; grupo B (GB) que recebeu cones de biovitrocerâmico I ou Biossilicato ${ }^{\circledR}$; e grupo C (GC) que recebeu cones de biovitrocerâmico II, assim chamado por apresentar 
a mesma composição do biovitrocerâmico I, porém submetido a processo maior de cristalização. Oito animais foram desprezados e substituídos durante o experimento.

A pesquisadora não conhecia qual biomaterial estava empregando nos diferentes grupos experimentais, tendo sido o cegamento feito pelo fornecedor dos implantes, que os separou nos três grupos, identificados pelas letras A, B e C. As letras só foram identificadas para a pesquisadora ao final do estudo.

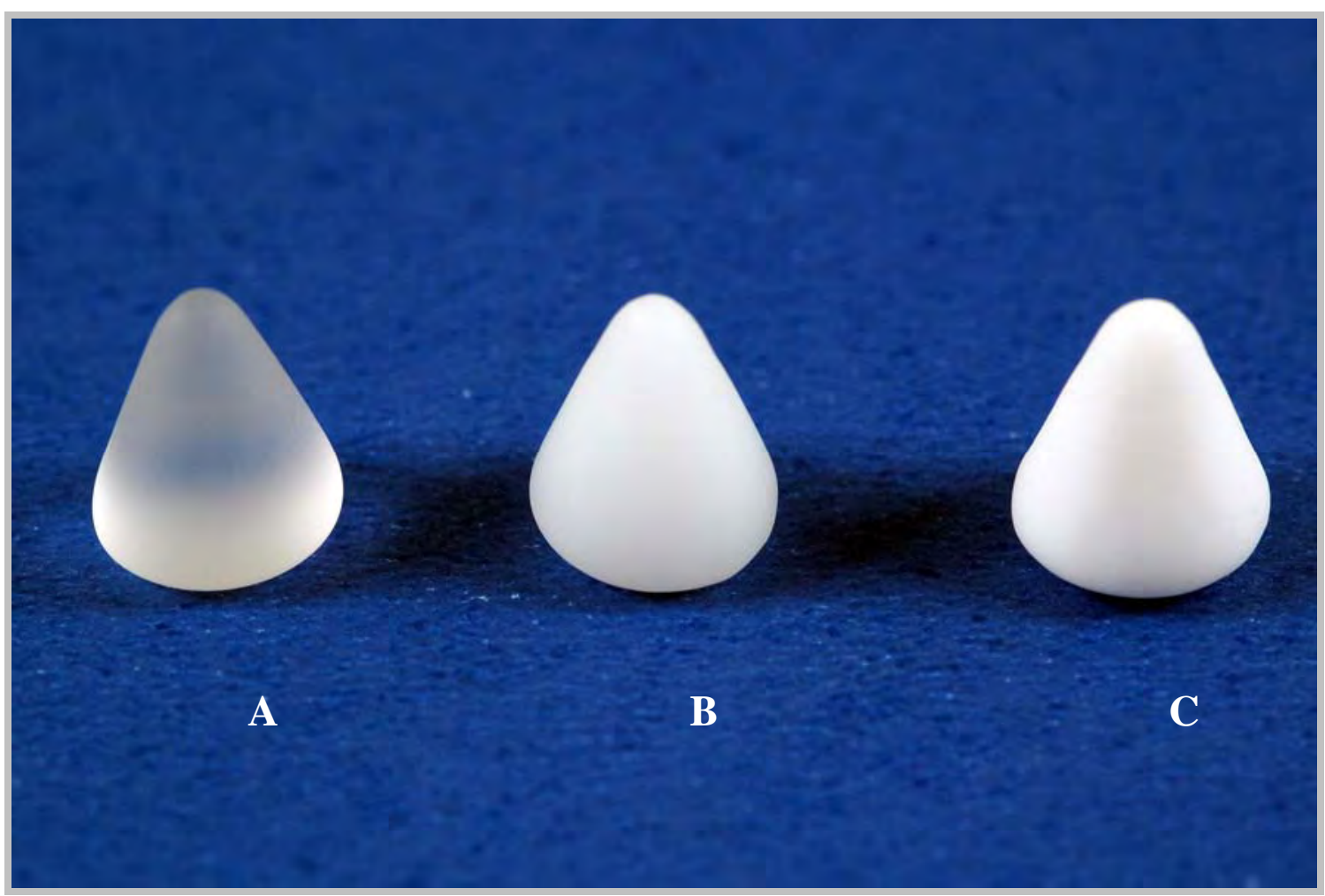

Figura 1. Imagem dos três tipos de cones, compostos pelos biomateriais utilizados: A) biovidro; B) biovitrocerâmico I; C) biovitrocerâmico II.

Depois de realizado o procedimento cirúrgico, foi feita nova aleatorização como meio de decisão para composição dos momentos experimentais, considerados momentos de sacrifício, como segue: 
- Momento 0 (M0): momento de coleta de exames bioquímicos, imediatamente antes da realização da cirurgia:

- Momento 1 (M1): 15 animais, cinco de cada grupo, permaneceram sete dias com os cones na cavidade eviscerada após o que, foram sacrificados;

- Momento 2 (M2): 15 animais, cinco de cada grupo, permaneceram 90 dias com os cones na cavidade eviscerada, após o que, foram sacrificados;

- Momento 3 (M3): 21 animais, sete de cada grupo, permaneceram 180 dias com os cones na cavidade eviscerada, após o que, foram sacrificados. Dois animais de cada grupo foram destinados para avaliação do material sob microscopia eletrônica de varredura e os outros cinco, para as mesmas análises histológicas propostas nos demais momentos do estudo.

\section{Variáveis estudadas}

Os biomateriais foram avaliados segundo as seguintes variáveis:

- Exame Clínico: os animais foram pesados no início do experimento e no momento de sacrifício. Foram avaliados diariamente após a realização do ato cirúrgico, por observação ectoscópica, feita sob luz ambiente. O exame visou sinais que denotassem alterações da saúde geral do animal, estimada pela atividade, apetite e atitude na gaiola, ou sinais que estivessem presentes no sítio operatório, com atenção especial aos sinais locais na região orbitária direita, avaliando-se a presença de sinais inflamatórios e/ou infecciosos, traduzidos por secreção, deiscência de sutura conjuntival ou outros sinais possíveis e presentes na face, além da observação da presença do cone 
implantado na cavidade orbitária. Também foi realizada a avaliação do peso dos animais, com o intuito de estabelecer possíveis alterações clínicas sistêmicas decorrentes do procedimento realizado.

- Exames Bioquímicos: foram realizados exames para verificação de possível absorção e repercussão sistêmica, decorrente da presença do biomaterial na cavidade orbitária. Foram colhidos exames para verificação da função hepática (TGO, TGP, LDH, FA), cardíaca (CPK) e renal (Uréia, Creatinina). Os exames foram colhidos imediatamente antes do procedimento cirúrgico (considerado padrão de normalidade para os exames ou momento zero - M0), e no momento do sacrifício do animal. Todos os exames foram realizados para todos os animais que receberam nas cavidades evisceradas os cones de biovidro, biovitrocerâmicoI e biovitrocerâmico II (Grupos A,B,C, respectivamente). Os valores observados foram transferidos para Tabela Excel para posterior análise estatística.

Todos os exames citados foram realizados em todos os animais que receberam nas cavidades evisceradas os cones de biovidro, biovitrocerâmico I e biovitrocerâmico II (Grupos A, B, C).

- Tomografia computadorizada: foi realizada nos coelhos dos três grupos, aos 45 dias após os cones terem sido colocados na cavidade anoftálmica, ou seja, nos animais do M2 e M3, já que os de M1 foram sacrificados após sete dias do procedimento cirúrgico. Este exame foi realizado com o intuito de pesquisar o posicionamento da prótese na órbita, verificando possível ocorrência de migração e a presença de alterações nos tecidos vizinhos, como presença de coleções ou processos inflamatórios ao redor dos cones implantados. 
- $\quad$ Exame Morfológico: o exame morfológico seguiu com a realização de três tipos de avaliação: histológica, morfometria e ultra-estrutural. O exame histológico foi feito para a avaliação da reparação tecidual inflamatória (tipo, localização e intensidade da reação) encontrada nos tecidos ao redor dos cones, com ênfase na celularidade (neutrófilos e eosinófilos) e a vascularização local, em lâminas coradas por Hematoxilina e Eosina (nos momentos M1, M2 e M3) e Picrosirius Red (nos momentos M1 e M3). O exame morfométrico foi realizado para avaliação quantitativa da pseudocápsula que se formou ao redor dos implantes, assim como da celularidade, seguindo a metodologia descrita a seguir. Também foi realizado exame ultra-estrutural, por meio de microscopia eletrônica de varredura, em dois coelhos de cada grupo, no momento M3. A preparação para o exame histológico, assim como o exame morfométrico foi feita no Laboratório Experimental da Faculdade de Medicina de Botucatu. O exame ultra-estrutural foi realizado no Laboratório de Microscopia eletrônica, pertencente ao Instituto de Biociências, da Universidade Estadual PaulistaCampus Botucatu.

\section{Sequência dos tempos experimentais}

Os animais foram transferidos do Biotério Central para as dependências dos Laboratórios Experimentais, local onde foram realizados os procedimentos operatórios e mantidos os animais.

Após a ambientação, foi colhida uma amostra de sangue para realização de exames bioquímicos e, em seguida, os animais foram anestesiados. 
Os olhos direitos dos coelhos foram eviscerados, com reposição do volume perdido usando cones, compostos por três tipos distintos de biomateriais: o biovidro; o biovitrocerâmico I; e o biovitrocerâmico II (Grupos A, B e C).

Desta forma, os grupos experimentais diferiram de acordo com o tipo de biomaterial que foi utilizado para reposição de volume nas cavidades evisceradas.

Os coelhos permaneceram em observação segundo o tempo estipulado para o experimento.

Nos animais de M2 e M3, após 45 dias do procedimento cirúrgico, foi realizado exame tomográfico, feito sob anestesia geral.

Transcorridos os dias previstos, os animais foram anestesiados, coletando-se novamente sangue para os exames bioquímicos, após o que, foram imediatamente sacrificados, sendo o conteúdo da órbita removido e preparado para exame morfológico. O preparo para exame morfológico está especificado a seguir.

\section{Metodologia utilizada na produção dos cones}

Todas os cones foram confeccionados por um mesmo profissional, Dr. Oscar Peitl, pertencente à Universidade Federal de São Carlos, no Departamento de Engenharia de Materiais, localizado no Laboratório de Materiais Vítreos - LAMAV. Todos apresentavam diâmetro anterior de $10 \mathrm{~mm}$, posterior de $3 \mathrm{~mm}$ e comprimento de $12 \mathrm{~mm}$, tendo sido confeccionados a partir de um molde de grafite para moldes de alta precisão, construído especificamente para este estudo. O peso das próteses foi de 1,19 $( \pm 0,02) g$. 


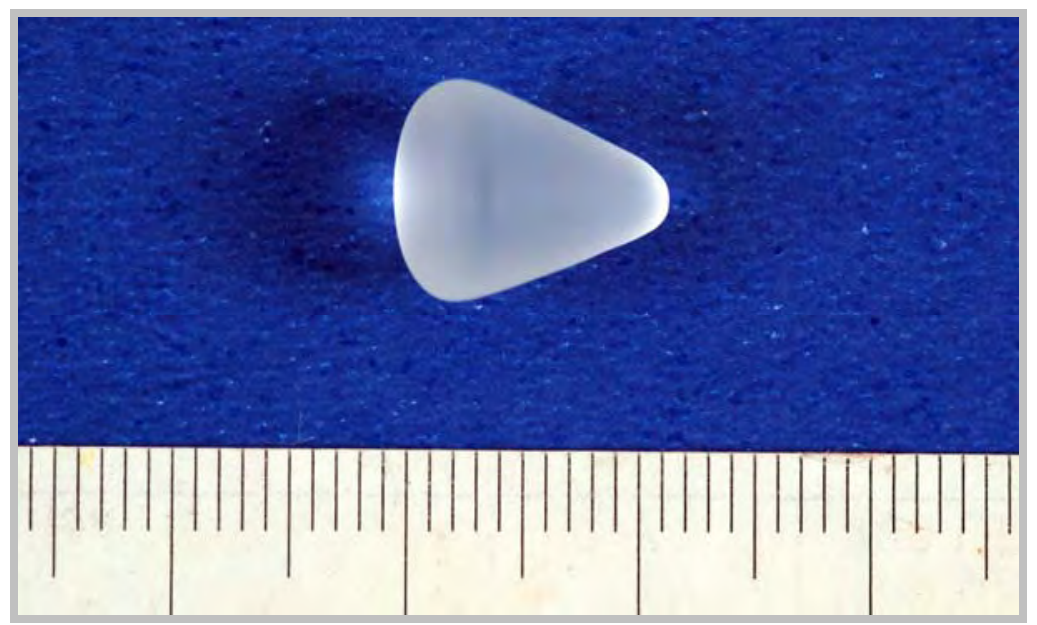

Figura 2. Vista lateral do cone de biovidro utilizado no presente experimento.

A obtenção destes cones iniciou-se com o preparo da matéria prima, que foi pesada na proporção para se obter a formulação desejada, utilizando-se balança com precisão mínima de 0,01g e colocada em um recipiente cilíndrico de polietileno de alta densidade, hermeticamente vedado.

Para garantir a homogeneidade química da mistura dos pós, o recipiente com a mistura foi colocado para girar na velocidade crítica de efeito “cascata” em um moinho de jarros por 2 horas.

Tabela 1. Composição Química do Biovidro e do Biosilicato.

\begin{tabular}{lccccc}
\hline Componente & $\mathrm{SiO}_{2}$ & $\mathrm{Na}_{2} \mathrm{O}$ & $\mathrm{K}_{2} \mathrm{O}$ & $\mathrm{CaO}$ & $\mathrm{P}_{2} \mathrm{O}_{5}$ \\
\hline Faixa de composição (wt\%) & $45,0-55,0$ & $15,0-25,0$ & $0-7,0$ & $15,0-35,5$ & $0-9,0$
\end{tabular}

(AMATO et al., 2003)

Após a mistura ter sido homogeneizada, foi conduzida ao forno de fusão. O forno empregado para a fusão foi o elétrico tipo botton load com resistência capaz de atingir até $1800^{\circ} \mathrm{C}$ de temperatura. A opção pelo aquecimento elétrico se deu por ser o sistema que anula toda contaminação proveniente da queima de combustível, como nos 
fornos aquecidos por gás natural ou petróleo. O cadinho empregado para a fusão foi confeccionado em platina pura (Pt 99,999\%), por ser um metal que não sofre nenhum ataque químico a elevadas temperaturas (até $1650^{\circ} \mathrm{C}$ ), proveniente do contato com o líquido do vidro fundido. Apesar de ser extremamente oneroso, o cadinho de platina é o material mais inerte conhecido, ao contrário dos cadinhos cerâmicos (Al2O3, ZrO2, Mulita, etc.), normalmente empregados pela indústria de vidros, os quais são fortemente atacados pelos elementos alcalinos (sódio). O ataque químico do vidro em estado líquido nos cadinhos cerâmicos leva a dissolução de parte dele que é incorporada à composição do vidro e se torna uma fonte de contaminação para os vidros fundidos nesses cadinhos. Por esse fato, fica inviável proceder à fusão em cadinhos cerâmicos.

O processo completo de fusão e eliminação das heterogeneidades (bolhas, estrias, infundidos) e obtenção do vidro homogêneo para a composição escolhida é de quatro horas, na faixa de 1250 a $1450^{\circ} \mathrm{C}$. Com o vidro fundido se procede ao seu vertimento em molde de grafite de alta densidade, já que este vidro possui uma estreita faixa de temperatura na qual pode ser moldado, com tempo para moldagem dos cones (com dimensões muito pequenas) extremamente curto (aproximadamente um segundo). Para viabilizar o preenchimento completo do molde nesse curto espaço de tempo é necessário se proceder ao vertimento em vácuo ou sob pressão, o que foi feito.

Após a moldagem, a temperatura decai rapidamente e em aproximadamente 15 segundos atinge $100^{\circ} \mathrm{C}$. Esse rápido resfriamento leva ao aparecimento de tensões internas no vidro que são indesejadas, pois podem conduzir à fratura completa da peça recém formada. Para eliminar as tensões da moldagem se faz o recozimento, que consiste em elevar a temperatura da peça acima da Temperatura de Transição Vítrea (Tg) por 15 minutos e resfriar lentamente até a temperatura ambiente, a uma taxa 
aproximada de $4^{\circ} \mathrm{C} / \mathrm{min}$. Este processamento é executado em forno mufla convencional (capacidade até $1200^{\circ} \mathrm{C}$ ) com aquecimento elétrico. Após o resfriamento, é possível cortar o excesso de vidro acumulado devido à moldagem, assim obtendo a geometria praticamente definitiva da prótese.

A peça de vidro é submetida a dois tratamentos térmicos para promover a sua cristalização. Inicialmente faz-se o tratamento para surgir núcleos de cristais no volume do vidro. Após esse processo de nucleação, faz-se o crescimento dos cristais conduzindo a inclusão vítrea a uma vitrocerâmica. A Tabela 2 apresenta a faixa de temperatura dos tratamentos térmicos de nucleação e crescimento utilizados na produção de cones de biovidro e biovitrocerâmico.

Tabela 2. Tratamento térmico empregado no Laboratório de Materiais Vítreos LAMAV, pertencente à Universidade Federal de São Carlos, para cristalizar o biovitrocerâmico nos processos de nucleação e cristalização.

TRATAMENTO TÉRMICO

\begin{tabular}{cccc}
\hline \multicolumn{2}{c}{ Nucleação } & \multicolumn{2}{c}{ Crescimento } \\
Temperatura & Tempo & Temperatura & Tempo \\
${ }^{\circ} \mathrm{C}$ & Minutos & ${ }^{\circ} \mathrm{C}$ & Minutos \\
$500-610$ & $30-9000$ & $650-850$ & $1-100$ \\
\hline
\end{tabular}

No biovitrocerâmico II, o processo é igual ao biovitrocerâmico I, porém fazse um terceiro tratamento térmico para promover um segundo crescimento, aparecendo assim, uma nova fase cristalina a base de fosfato.

O fluxograma apresentado abaixo demonstra resumidamente o processo utilizado para a obtenção do biovitrocerâmico (Fluxograma 1). 


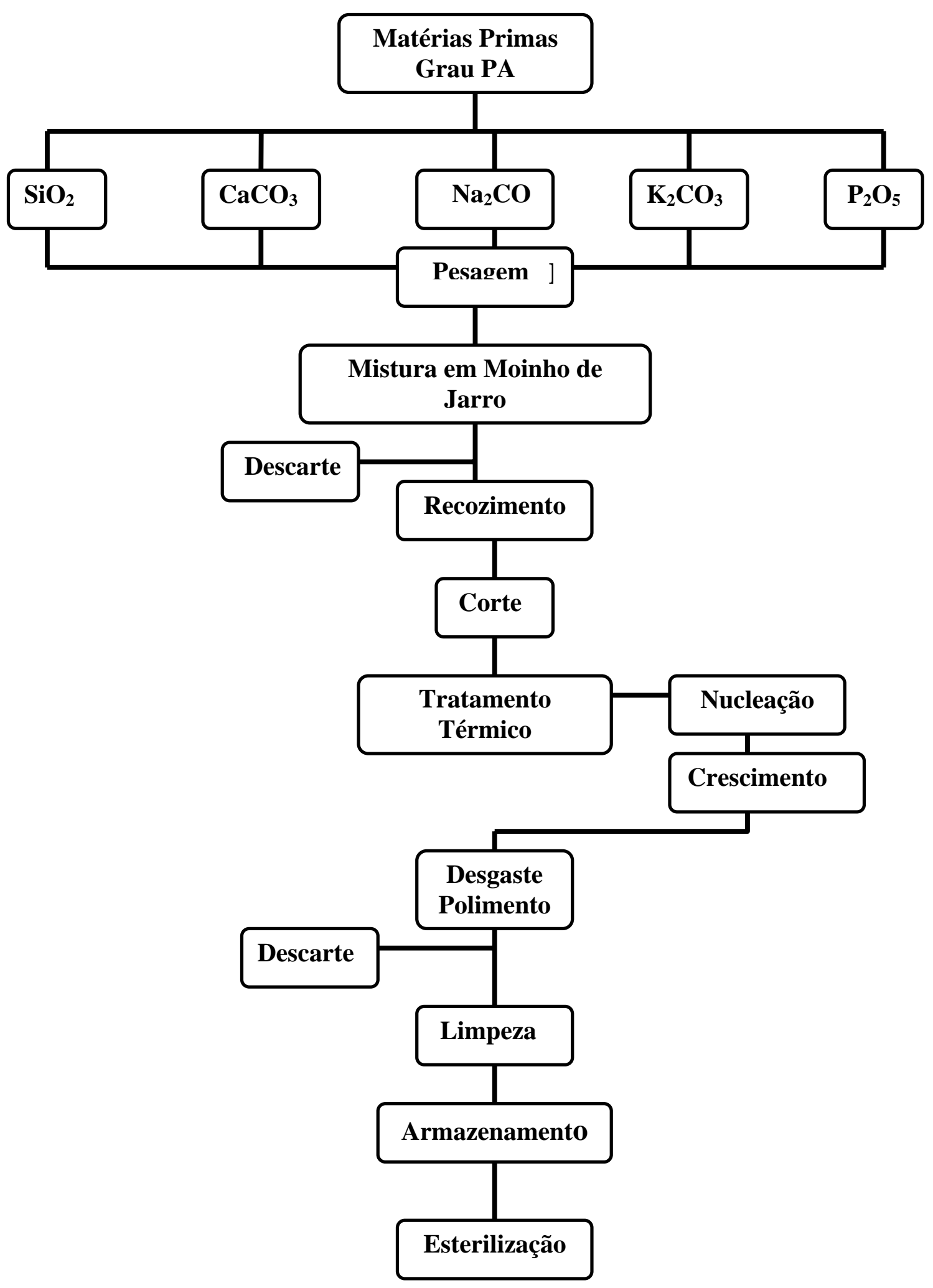

Fluxograma 1. Apresentação do processo de obtenção dos implantes de biovidro e biovitrocerâmico. 
Para concluir a prótese com sua dimensão final procedeu-se a um desbaste e polimento do stem, assim garantindo que todos os cones possuíssem as mesmas dimensões. Após o acerto dimensional do cone foi efetuada a limpeza, imergindo-os em um banho de acetona (PA) dentro de um equipamento de ultrassom, por 10 minutos. Após o banho em ultrassom os cones foram devidamente mantidos em recipientes lacrados, contendo acetona, e encaminhados para esterilização individual, feita em Óxido de Etileno, pela empresa Oximed (São José do Rio Preto- SP), permanecendo no máximo dois dias embalados e esterilizados, tendo sido logo colocados na órbita.

\section{Técnica cirúrgica empregada para a colocação do cone na cavidade eviscerada e detalhamento da sequência experimental}

Todos os procedimentos cirúrgicos foram realizados, no Laboratório Experimental do Departamento de Oftalmologia/Otorrinolaringologia/Cirurgia de Cabeça e Pescoço, da Faculdade de Medicina de Botucatu - UNESP.

1. Aleatorização dos animais experimentais para composição dos grupos: A, B e C

2. Retirada e preparo do sangue para exames bioquímicos

3. Anestesia geral utilizando Zoletil ${ }^{\circledR} 50$ (cloridrato de tiletamina $e$ cloridrato de zolazepam, Virbac, France), na dose de $15 \mathrm{mg} / \mathrm{kg}$

4. Posicionamento do coelho sobre a mesa cirúrgica, em decúbito lateral esquerdo, de forma que o olho direito permanecesse voltado para cima 
5. Instilação de 1 gota de colírio anestésico no olho a ser operado, para complementação da analgesia

6. Antissepsia do olho direito com Polivinilpirrolidona-iodo (PVPI)

7. Colocação de campo oftalmológico estéril e blefarostato para abertura palpebral

8. Abertura córneo-escleral com bisturi lâmina 11 (Two Arrows, fabricação da RPC, Shanghai Med SN, China), aproximadamente à $1 \mathrm{~mm}$ do limbo, sendo feita a paracentese, com complementação da abertura de $360^{\circ}$, usando tesoura tipo Westcott, para separação da córnea em relação à esclera, sendo desprezada a córnea

9. Evisceração do conteúdo do olho direito, sendo feita a remoção deste com uma cureta pequena e pinça de conjuntiva e utilizando-se uma espátula para separar a esclera do tecido uveal

10. Com o auxílio de compressas de gaze (Plascalp - Produtos Cirúrgicos Ltda, BA) e cotonetes (Johnson \& Johnson, SP), foi feita a remoção dos restos uveais da esclera e a hemostasia dos vasos sangrantes da cavidade escleral

11. Após a hemostasia, procedeu-se a colocação dos cones, conforme grupo experimental

12. Fechamento da incisão cirúrgica foi realizado por meio de sutura contínua, com fio inabsorvível trançado 6-0 (Mersilene 6-0 - Ethicon, Johnson \& Johnson, SP), nos planos da esclera e conjuntiva

13. Instilação de 0,1 ml de solução oftálmica Gatifloxacino colírio (Zymar, Allergan Laboratórios do Brasil) 
14. Novamente foram sorteados e divididos os animais em três subgrupos experimentais, agora para determinação do tempo de acompanhamento, denominados de momentos experimentais, escolhidos como momentos para sacrifício dos animais

15. Após 45 dias do procedimento, os animais de M2 e M3 foram anestesiados, sendo submetidos ao exame tomográfico

16. Transcorrido o tempo estipulado para o seguimento, os animais foram anestesiados da mesma forma apresentado no item 2, sendo, em seguida, colhido sangue para exames bioquímicos

17. Remoção do conteúdo orbitário e preparo para o exame histológico, morfométrico e ultra-estrutural. 



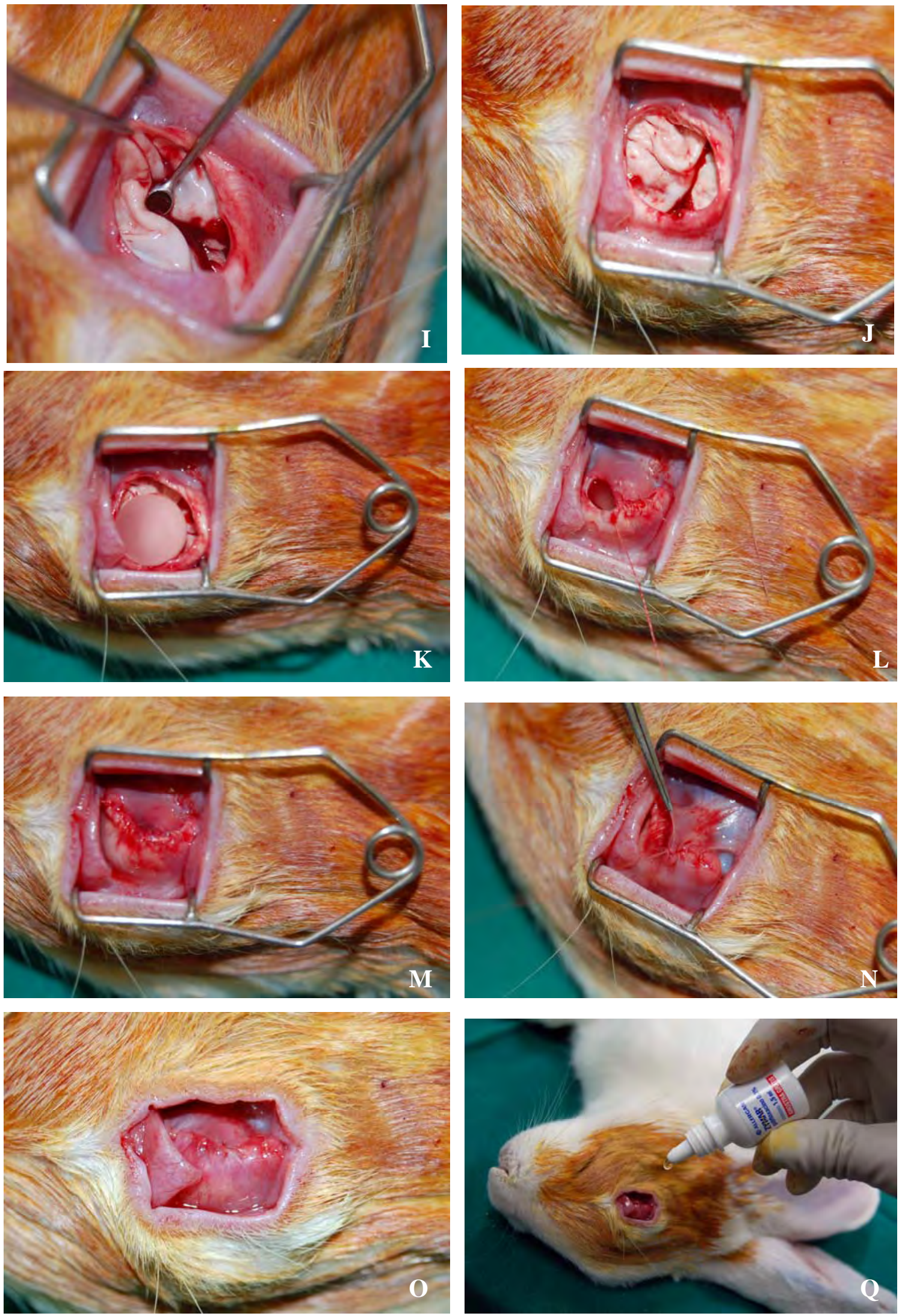
Figura 3. Sequência do procedimento cirúrgico de evisceração realizada nos coelhos, seguida da colocação dos cones dos diferentes biomateriais. A) Posicionamento do coelho em decúbito lateral esquerdo, de forma que o olho direito permanecesse voltado para cima; B) Instilação de colírio anestésico; C) Antissepsia usando PVPI; D) Paracentese com bisturi lâmina 11; E) Abertura córneo-escleral com tesoura tipo Westcott; F) Separação da córnea e esclera; G) Retirada da córnea; H) Evisceração com remoção das estruturas intraoculares; I) Limpeza da capa escleral usando cureta; J) Apresentação da capa escleral após remoção das estruturas intraoculares; K) Colocação do cone na cavidade; L) Sutura escleral com mersilene 6-0; M) Aspecto da sutura escleral completa; N) Sutura conjuntival com mersilene 6-0; O) Aspecto da finalização do procedimento P) Instilação de solução oftálmica de Gatifloxacino colírio ao final do experimento.

\section{Método de coleta dos exames bioquímicos}

A coleta de sangue dos animais para os exames bioquímicos foi realizada antes do procedimento cirúrgico e uma segunda bateria de exames bioquímicos foi colhida antes da eutanásia.

Os animais foram colocados em um suporte adequado para tal procedimento.

Foram coletados $5 \mathrm{ml}$ de sangue com seringa ( $B D$ precision glide ${ }^{\circledR}, P R$ ) e agulha descartáveis, por meio da veia auricular conforme apresentado na figura 4. 


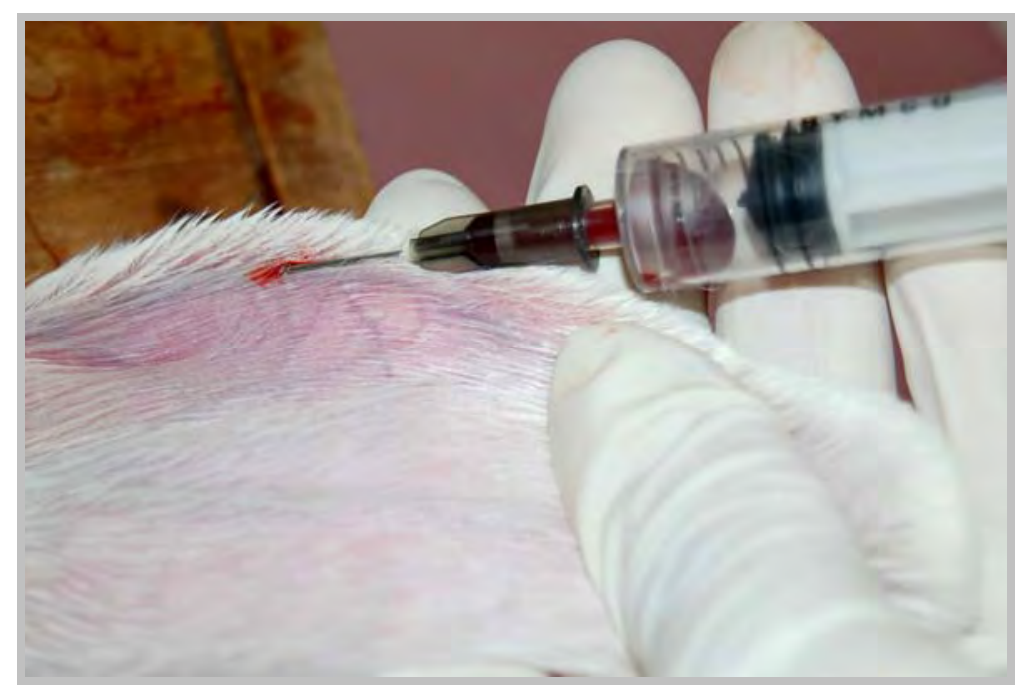

Figura 4. Demonstração da coleta de sangue da veia auricular do coelho para análises bioquímicas.

O conteúdo da seringa foi imediatamente transferido de forma lenta, com o jato dirigido para a parede do tubo de ensaio sem anticoagulante, para evitar lise das células sanguíneas e deixado em repouso por 1 hora.

O tubo foi então, submetido à centrifugação com 3000 rotações/minuto, por 20 minutos, em temperatura ambiente, obtendo assim o sangue fracionado.

O soro foi separado usando uma pipeta e congelado em dois tubos Eppendorf para cada amostra.

Os exames bioquímicos foram realizados no Laboratório Clínico, pertencente ao Hospital Veterinário da Faculdade de Medicina Veterinária e Zootecnia de Botucatu - UNESP, a partir do soro congelado. 


\section{Preparo para análise histológica e detalhamento do exame morfométrico}

Após o sacrifício, os cones envoltos por esclera, removidos da cavidade orbitária,, foram fixados no formol tamponado a 10\%. Após três dias de fixação, iniciou-se a preparação para o exame histológico.

A capa escleral que evolvia os cones foi seccionada, os cones foram removidos do seu interior e apenas a capa escleral seguiu a preparação para exame histológico e morfométrico.

O material foi desidratado em série crescente de seis cubas de álcoois (80100\%), diafanizado em três cubas de xilol, e por fim, em três cubas de parafina (temperatura entre 50 e $60^{\circ} \mathrm{C}$ ), permanecendo por uma hora em cada uma dessas cubas, e, em seguida, processado no auto-técnico (Leica TP 1020, Alemanha).

Em seguida, foi incluído em blocos de parafina no inclusor auto-técnico (Leica EG 1160, Alemanha), cortado em espessura de quatro $\mu$ m para coloração com Hematoxilina-Eosina (HE) e de seis $\mu \mathrm{m}$ para Picrosirius Red (exame específico para análise do colágeno) em micrótomo rotativo (Leica RM 2155, Alemanha).

Os melhores cortes foram selecionados e separados. Estes foram colocados em álcool $30 \%$, seguido de banho-maria em temperatura a $50^{\circ} \mathrm{C}$ para estirar, sendo colocados de dois a quatro cortes em lâminas (Knittel, Alemanha), levadas a estufa a $60^{\circ} \mathrm{C}$, por aproximadamente uma hora para desparafinizar.

As lâminas destinadas à avaliação de Hematoxilina-Eosina foram finalmente colocadas no aparelho Auto-Stainer XL, para coloração pela técnica de Hematoxilina 
(QEEL - Química especializada Erich Ltda, SP) e Eosina (Merck - Alemanha) (HE), sendo montadas no aparelho (Leica CV 5000), cobertas com lamínulas (Knittel, Alemanha).

As lâminas destinadas à avaliação de Picrosirius Red foram finalmente colocadas no aparelho Auto-Stainer XL, para coloração pela técnica de Picrosirius Red (Direct Red 80, Altrich Chemical Company.inc, EUA), sendo montadas no aparelho (Leica CV 5000), cobertas com lamínulas (Knittel, Alemanha).

Durante toda a análise histológica e morfométrico, as lâminas permaneceram identificadas com o número do preparo, sem revelação do grupo e nem momento do estudo.

A avaliação das lâminas foi realizada empregando-se o microscópio LEICA DM LS, acoplado à câmara de vídeo que envia imagens digitais ao computador dotado de programa de análise de imagens Image Pro-plus (Media Cybernetics, Silver Spring, Maryland- USA).

As avaliações foram realizadas adotando-se a padronização de análise de cortes em quatro posições: anterior, posterior, três horas e nove horas, conforme a disposição do corte sobre a lâmina histológica (figura 5). 


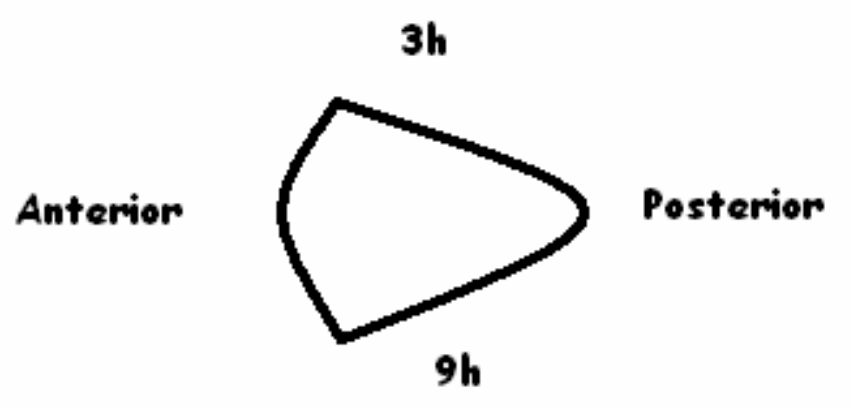

Figura 5. Figura contendo um cone esquemático, com a identificação das regiões padronizadas para análise na lâmina histológica.

O exame morfométrico foi feito utilizando as lâminas coradas pelo método de Hematoxilina-Eosina (HE), sendo quantificada a espessura da pseudocápsula formada entre o tecido escleral e o cone, nos 4 locais referidos nas figuras 5 e 6 , efetuando-se a medição em três pontos diferentes e adjacentes, em cada uma das posições, para cálculo dos valores médios. 


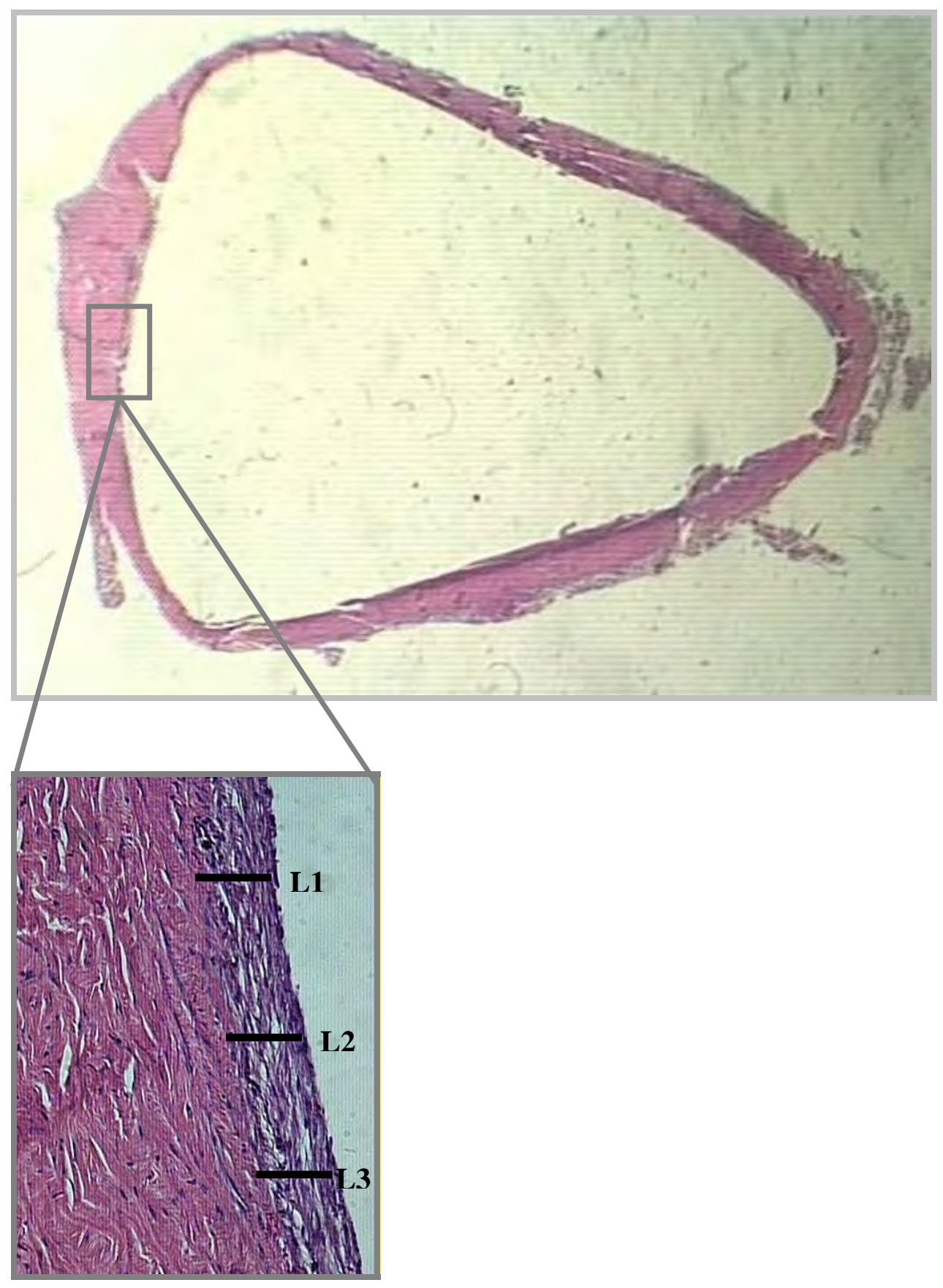

Figura 6. Demonstração da região de análise da espessura da pseudocápsula, realizada na coloração de HE, em três locais (L1, L2 e L3) de cada uma das regiões apontas na figura 5,, usando a lupa e no aumento de $40 \mathrm{X}$. 
Também foi realizado exame morfométrico quantificando-se a reação inflamatória que ocorreu após a colocação dos cones na cavidade anoftálmica, seguindo a mesma sistemática utilizada para o exame da pseudocápsula, ou seja, nas regiões anterior, posterior e três e nove horas, em três pontos distintos em cada uma das regiões. A reação inflamatória foi analisada, de acordo com o tipo e quantidade de células inflamatórias encontradas, utilizando o sistema de avaliação em cruzes (1+ a 4+), de modo que quanto maior o número de cruzes, maior a inflamação.

As lâminas destinadas à coloração de Picrosirius Red foram utilizadas para a quantificação da fração de colágeno intersticial (CVF), por meio de vídeodensitometria. As imagens dos tecidos da cavidade anoftálmica foram capturadas por computador IBM compatível e analisadas por software de análise de imagens Image Pro-plus (Media Cybernetics, Silver Spring, Maryland, USA). Os elementos do tecido avaliado foram identificados de acordo com os níveis de cor: as fibras colágenas apareceram vermelhas; os miócitos amarelos; e os espaços, brancos. O perfil digitalizado foi analisado pelo computador que calcula o volume de fração do colágeno como a soma de toda área do tecido conectivo, dividido pela soma da área de tecido conectivo e a área do miócito. Em média foram analisados 10 campos, utilizando a objetiva de 40X. Esta contagem foi realizada somente na região interna da capa escleral, ou seja, região que se encontrava em contato com o cone utilizado excluindo-se o colágeno que se encontrava na porção externa da esclera e do tecido que não apresentava contato com a prótese empregada.

A fração de colágeno existente na pseudocápsula foi analisada quantitativamente, comparando-se os momentos M1 e M3, por meio de análise de pontos. Para isto, cortes histológicos com espessura de $6 \mu \mathrm{m}$, corados por Picrosirius Red, foram examinados com objetiva de 40X e ocular dotada de retículo 10 colunas por 10 linhas. A percentagem do volume de fração de colágeno foi calculada de acordo com a equação (PEREIRA, 2001): 


$$
\operatorname{Cvf}(\%)=(\mathrm{Pc} / \mathrm{Pf}) \times 100
$$

\section{Onde:}

Cvf: Volume de fração de colágeno

Pc: número de intersecções da grade quadriculada com o colágeno

Pf: número total de intersecções dentro da área de referência

\section{Metodologia utilizada para a realização dos exames de Tomografia}

\section{Computadorizada}

O Tomógrafo utilizado para a realização dos exames dos coelhos foi o pertencente à Faculdade de Medicina Veterinária e Zootecnia da Universidade Estadual Paulista- UNESP Campus de Botucatu. O aparelho é da marca Shimadzu, modelo SCT7800TC (figura 7).

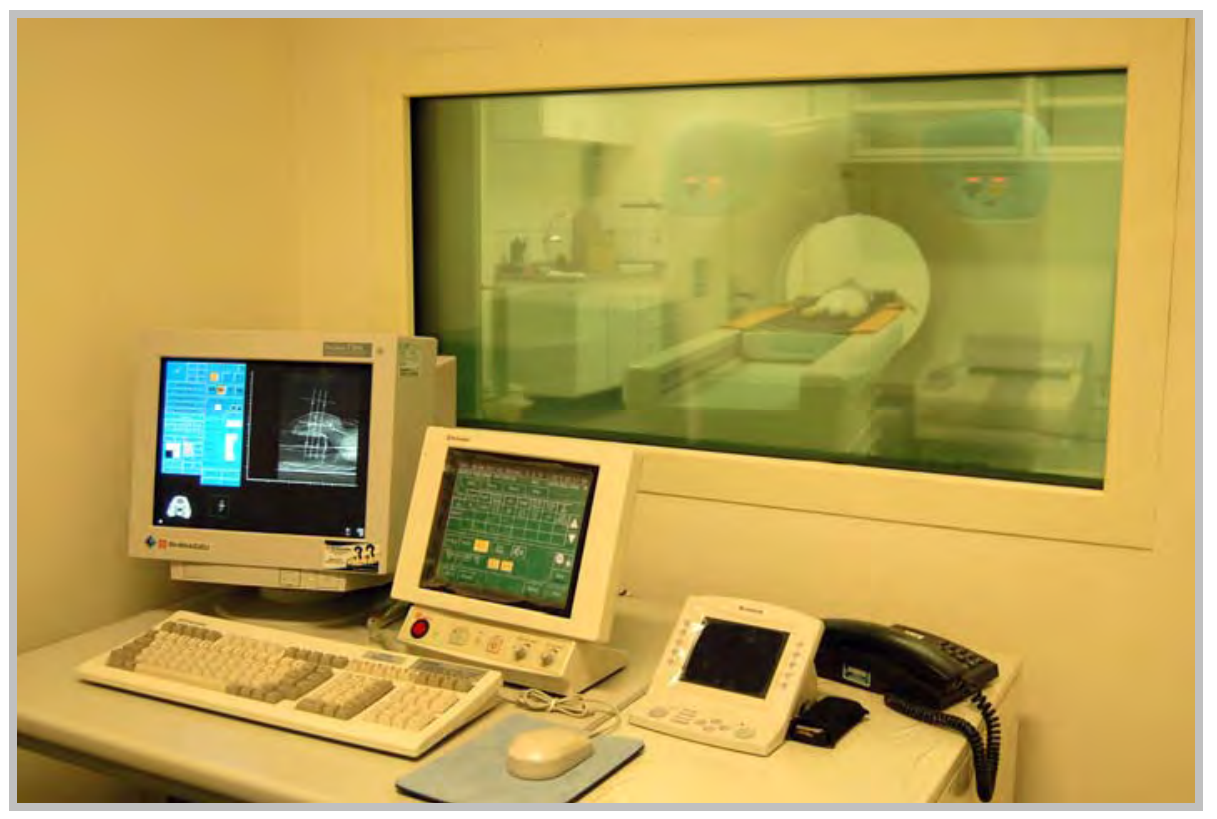

Figura 7. Fotografia da estação de comando do Tomógrafo da Faculdade de Medicina Veterinária e Zootecnia da Universidade Estadual Paulista- UNESP Campus de Botucatu. 
Os animais foram previamente anestesiados com Zoletil®, na dosagem de 15 mg/kg, posicionados ventralmente, com o crânio apoiado e elevado. (Figuras 8 e 9). Foram realizados cortes transversais no sentido rostro-caudal da cabeça, angulados paralelamente à topografia da órbita, com área total de corte de 26 mm de extensão, com os seguintes parâmetros: 120kVp e 160mA. Os cortes foram feitos de 1x1mm (um mm de espessura por um mm de intervalo de reconstrução) e as imagens avaliadas em janela óssea e de partes moles, com o FOV ( Field Of View- Campo de Visão) de $11 \mathrm{~cm}$.

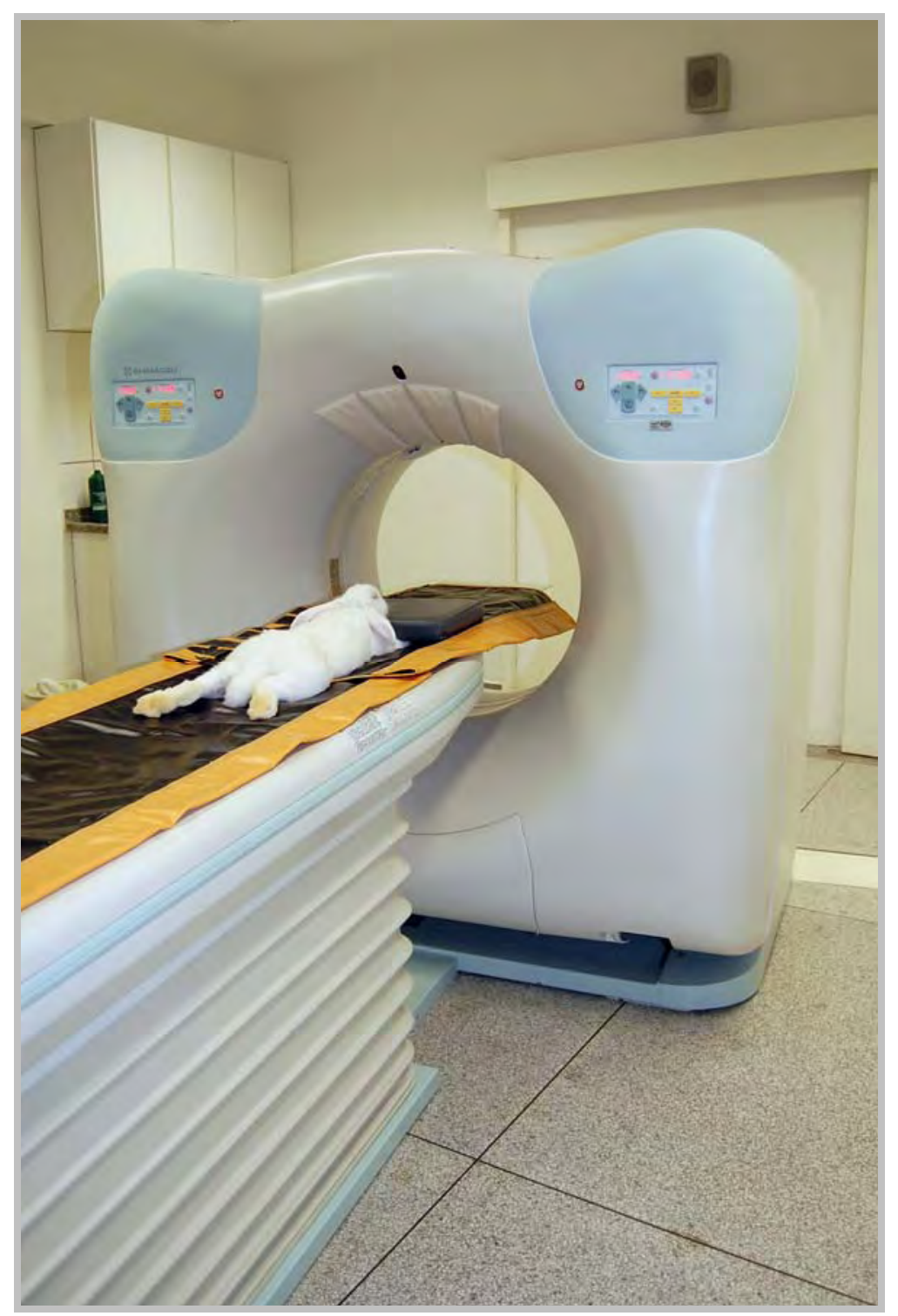

Figura 8. Coelho posicionado para exame de Tomografia Computadorizada, Faculdade de Medicina Veterinária e Zootecnia da Universidade Estadual Paulista- UNESP Campus de Botucatu. 


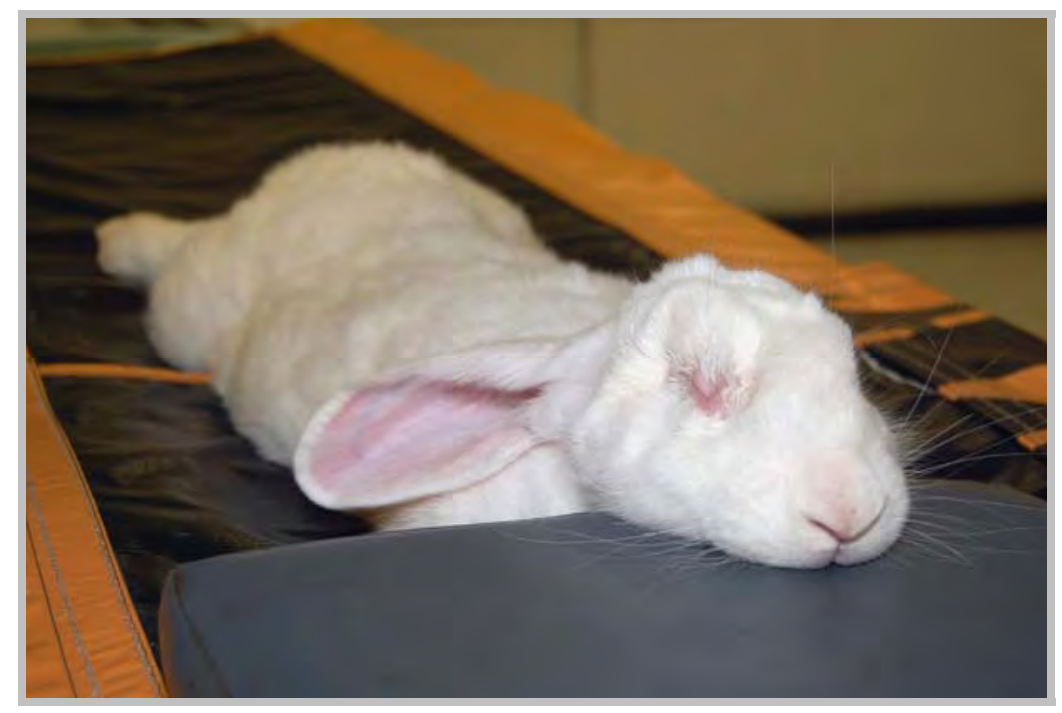

Figura 9. Animal anestesiado e posicionado ventralmente com o crânio apoiado e elevado para a realização da Tomografia Computadorizada.

\section{Microscopia Eletrônica de Varredura}

Conforme descrito nos momentos experimentais, dois animais de M3 de cada um dos grupos experimentais foram submetidos ao exame ultra-estrutural.

Os cones envoltos por esclera foram extraídos das cavidades orbitárias dos coelhos em M3, logo após a retirada, foram cortados com bisturi lâmina 15 (Two Arrows, fabricação da RPC, Shanghai Med SN, China) de modo a se produzir um sulco na esclera que revestia o cone e, em seguida, foram partidos ao meio, com auxílio de uma lâmina diamantada (KG Discos Flexíveis diamantados, Brasil), ligada a um motor de 3.000 rotações por minuto. Todo o procedimento foi feito sob irrigação com soro fisiológico a 0,9\%, com uso de seringa e agulha (figura 10). Após ser partido (figura 11), o material foi fixado em glutaraldeído 2,5\% em tampão fostato com $\mathrm{pH} 7,3$ (cacodilato de sódio 0,1M) por um tempo longo (até 24 h), já que a duração prolongada da fixação aumenta a penetração do fixador e a resistência física da amostra. Em 
seguida a amostra foi lavada por três vezes com duração de 10 minutos cada vez, com água destilada, com a finalidade de remover resíduos. Em seguida, foi realizada a pósfixação em tetróxido de ósmio 0,5\% em água destilada por 30 minutos para prevenir a extração de lipídios na fase de desidratação. A desidratação foi então iniciada em série crescente de etanóis (7,5\% a 100\%), ficando o material sempre submerso durante três horas. Então, as amostras foram transferidas para o aparelho de ponto crítico Balzers CPD-020, onde foram feitas várias substituições com dióxido de carbono líquido $\left(\mathrm{CO}_{2}\right)$ para promover a secagem em condições mais favoráveis. As amostras secas foram, então, montadas em “stubs” (porta amostra para Microscópio de Varredura) e, em seguida, cobertas com $10 \mathrm{~nm}$ de ouro em metalizador MED-010 da Balzers (para promover e aumentar a condutividade). Neste momento as peças estavam prontas para serem analisadas no Microscópio Eletrônico de Varredura SEM 515 - Philips, sob tensão de 20KV, pertencente ao Instituto de Biociências de Botucatu, da Universidade Estadual Paulista (SILVEIRA, 1998). Todos estes procedimentos seguem o protocolo daquele Laboratório e consta de material apostilado produzido pelos responsáveis pelo serviço. O exame ultra-estrutural foi realizado com o intuito de avaliar a superfície de contato entre o cone e a esclera, em diversos aumentos e observando-se a superfície nos quatro pontos avaliados também no exame histológico (anterior, posterior, três e nove horas). 


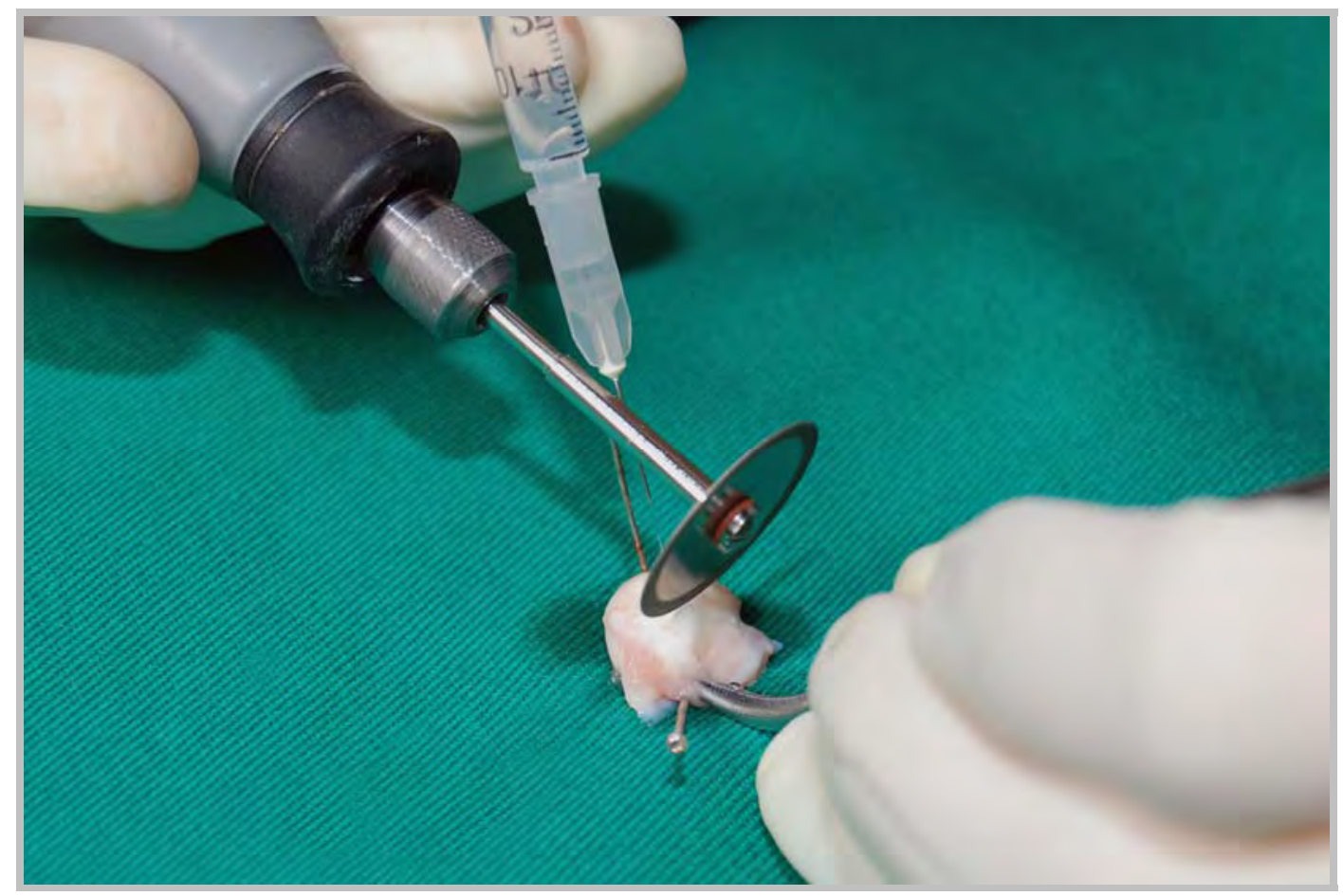

Figura 10. Esclera envolvendo o cone removidos da cavidade orbitária após o sacrifício do animal. Demonstração do método utilizado na partida do material de estudo ao meio com auxílio de uma lâmina diamantada ligada a um motor de 3.000 rotações por minuto, sob irrigação com soro fisiológico a $0,9 \%$.

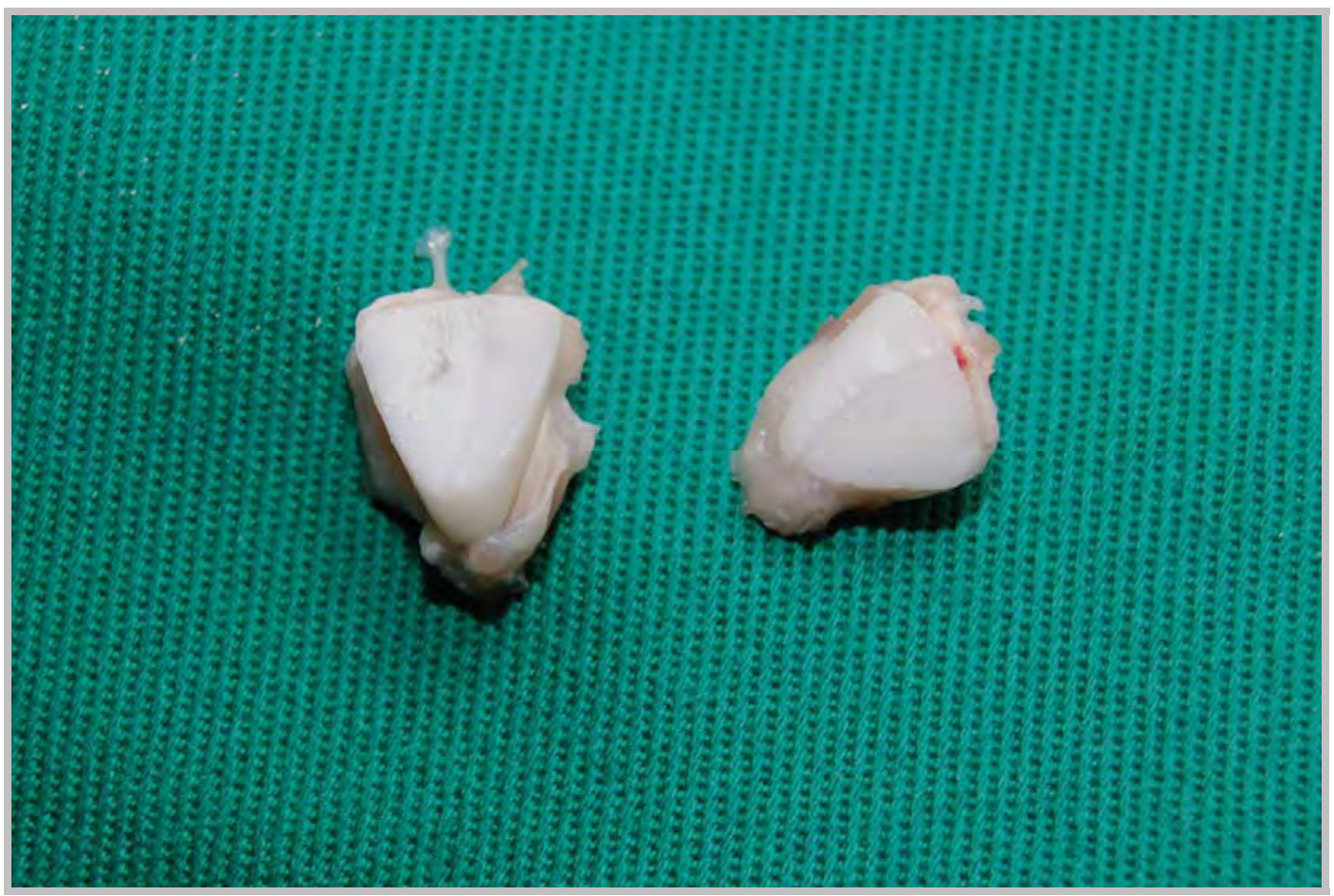

Figura 11. Material de estudo partido ao meio, mostrando o cone firmemente aderido à esclera, imediatamente antes da fixação em glutaraldeído. 
A descrição apresentada a seguir mostra a técnica para a preparação das amostras para avaliação em Microscopia Eletrônica de Varredura passo-a-passo:

1. Fixação: o material removido da cavidade orbitária foi fixado em glutaraldeído 2,5\%, em tampão fostato, com pH 7.3.

2. Lavagem: em água destilada (três vezes por 10 minutos cada uma).

3. Pós-fixação: em tetróxido de ósmio 0,5\%, em água destilada, por 30 minutos.

6. Desidratação em série crescente de etanol (7,5\% a 100\%).

7. Secagem: aparelho de ponto crítico Balzers CPD-020 utilizando o dióxido de carbono líquido $\left(\mathrm{CO}_{2}\right)$.

8. Montagem: amostras secas montadas em "stubs".

9. Cobertura: amostras cobertas com $10 \mathrm{~nm}$ de ouro em metalizador MED-010 da Balzers.

10. Análise: após o preparo, o material foi analisado no Microscópio Eletrônico de Varredura SEM 515 - Philips, sob tensão de 20KV (figura 12). 


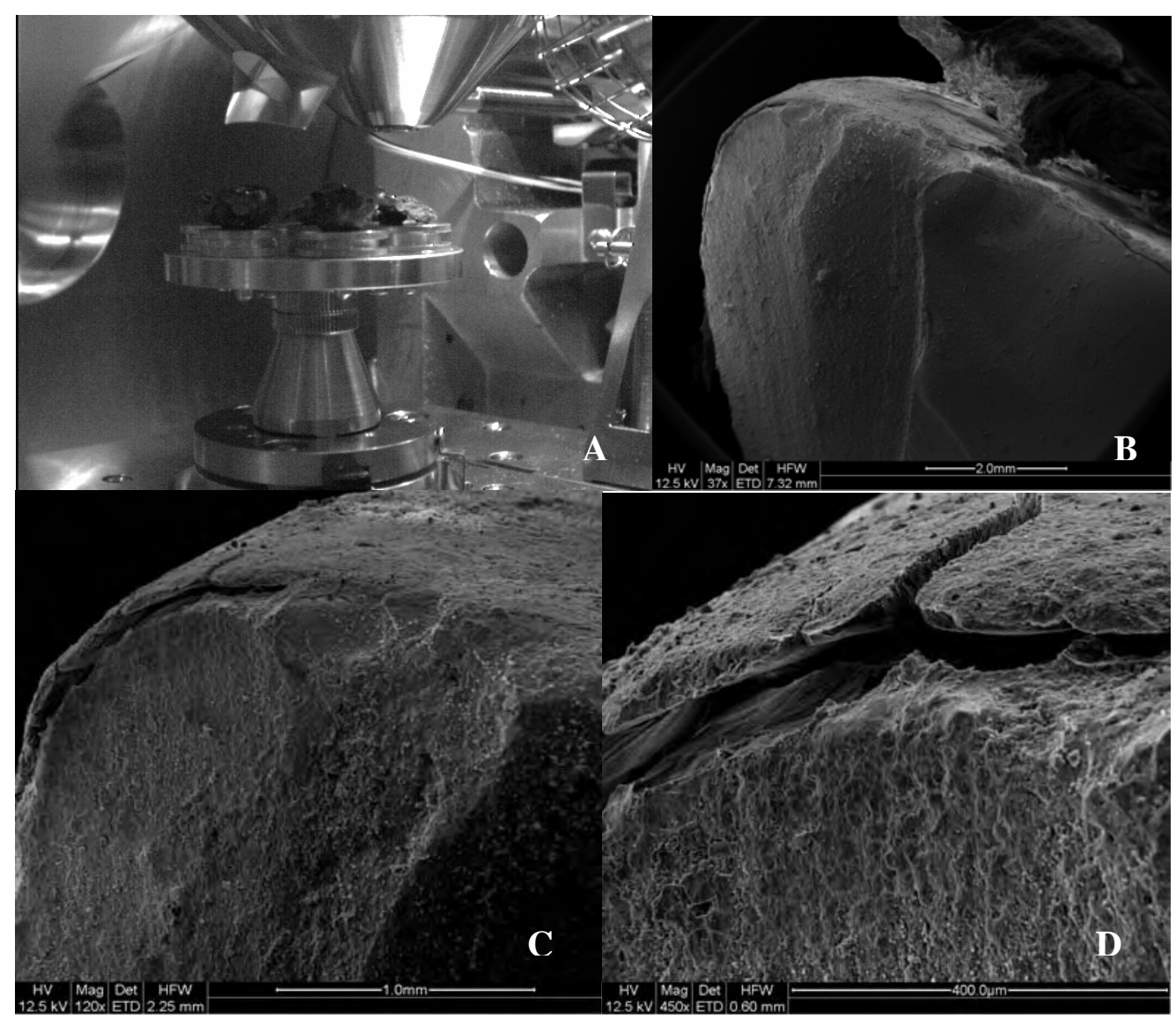

Figura 12. Imagens do exame de Microscopia de Varredura. A) Material colocado nos "stubs" dentro do Microscópio Eletrônico de Varredura sob vácuo. B) Imagem da superfície do cone com aumento de 37X. C) Idem com aumento de 120X. D) Idem com aumento de 450X.

\section{Manutenção dos animais}

Os animais foram acondicionados em gaiolas individuais, em ambiente com temperatura e iluminação controladas, recebendo alimentação a base de ração para a espécie e água ad libitum. Todos os dias, pela manhã, os coelhos foram observados, sendo feita a higiene das suas pálpebras e conjuntiva, utilizando soro fisiológico 0,9\% e algodão. Primeiramente removia-se as secreções que se encontravam acoladas aos pêlos, seguida da remoção da secreção do saco conjuntival e das crostas aderidas às margens palpebrais usando cotonetes. Os animais não foram anestesiados para tal tarefa, 
não demonstrando dor a manipulação. Esta tarefa foi realizado por um residente de Oftalmologia (Emerson Hashimoto) e por uma bolsista de Iniciação Científica (Amanda Dias de Morais).
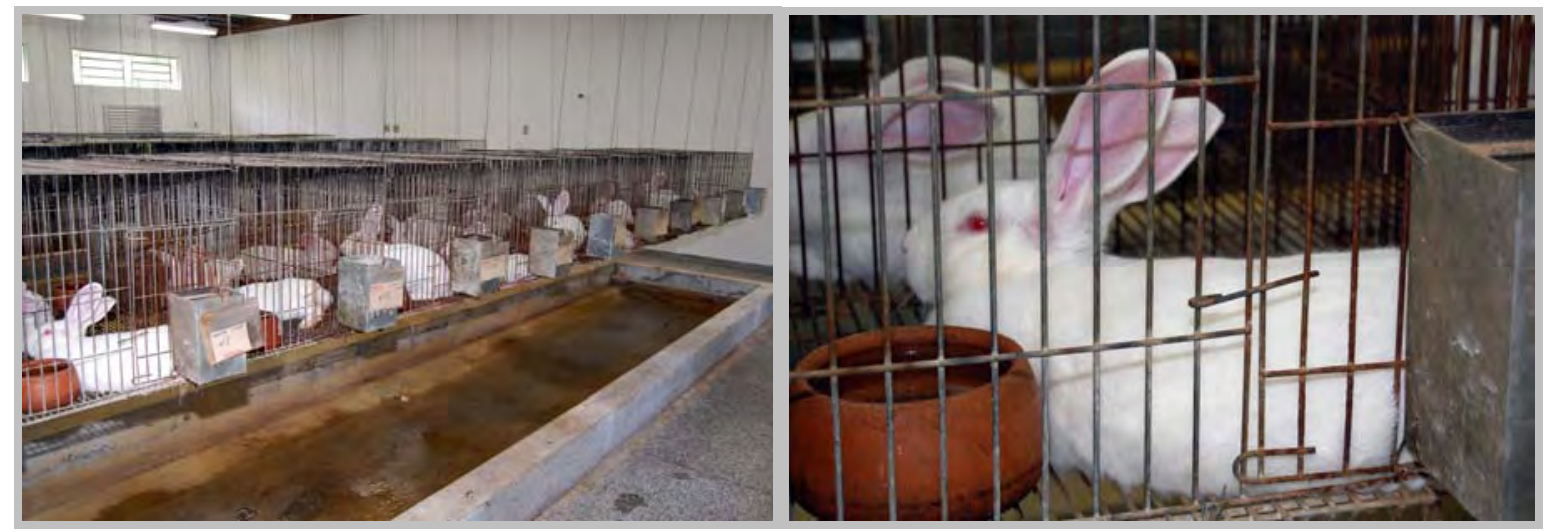

Figura 13. Fotografia do Biotério de Manutenção dos animais utilizados no experimento, com detalhe dos coelhos acondicionados em gaiolas individuais.

\section{Sacrifício dos animais}

Os animais foram sacrificados usando-se sobre dose de Cloridrato de Ketamina (Dopalen- Vetbrands-SP) pela via intramuscular, nos tempos idealizados para a pesquisa.

Após o sacrifício, foi removido o cone juntamente com a esclera e o tecido orbitário adjacente (figura 14), usando tesoura de argola e pinça de conjuntiva. Em seguida, o material foi colocado em Formol tamponado 10\% (Rioquímica, SP) para fixação. 


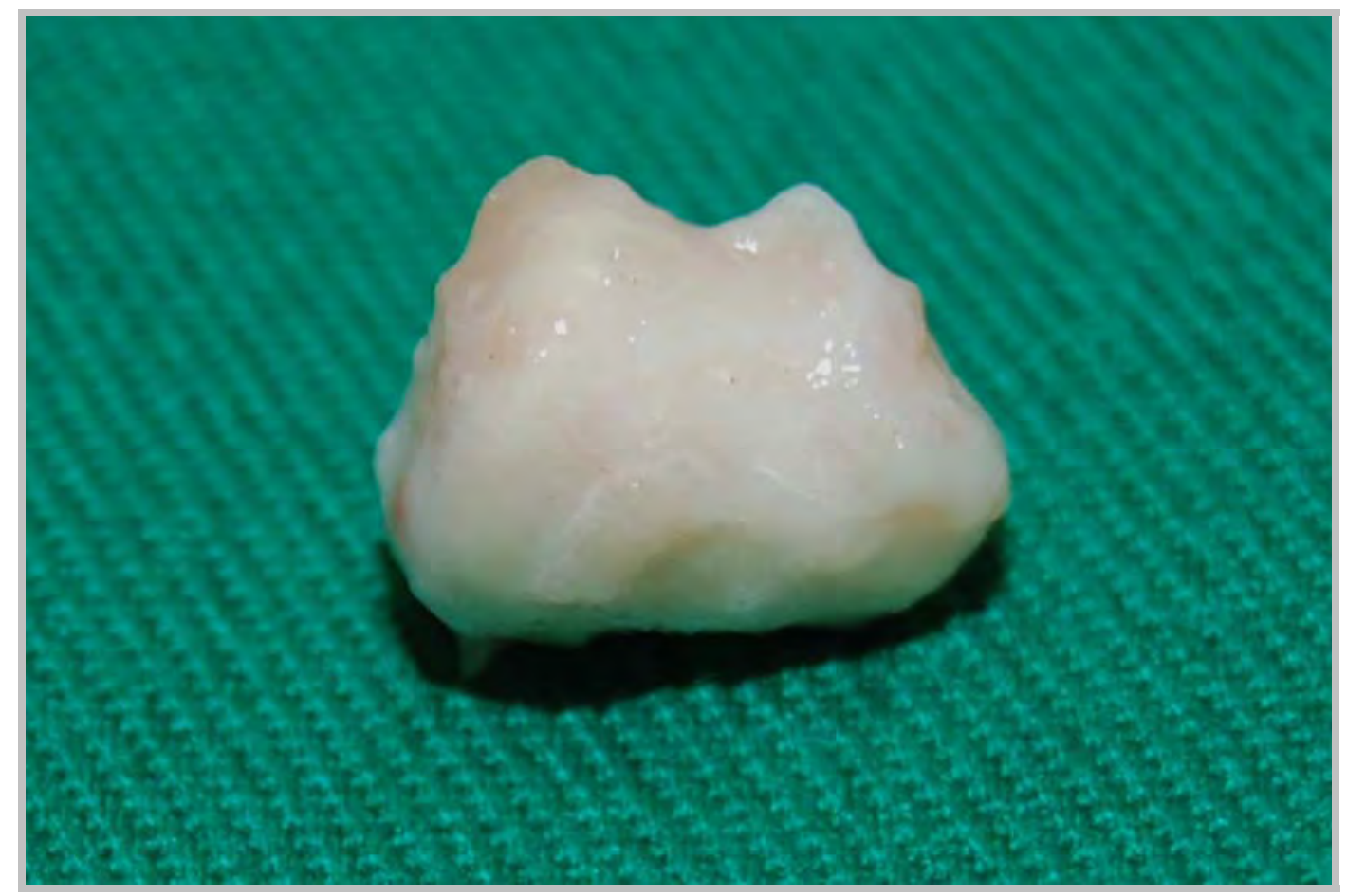

Figura 14. Material retirado imediatamente após eutanásia, identificando-se a esclera envolvendo o cone de biomaterial estudado.

\section{Avaliação Estatística}

Todos os valores encontrados nos exames bioquímicos (CPK, LDH, FA, TGO, TGP, Uréia e Creatinina) foram transferidos para planilhas Excel e submetidos à análise estatística, utilizando-se a técnica de Análise de Variância para o modelo com dois fatores complementada com o teste de comparações múltiplas de Tukey, usando média e desvio padrão para o estudo da Uréia e Creatinina. Para o estudo do restante dos exames laboratoriais (CK, LDH, FA, TGO, TGP), a técnica empregada foi a de Análise de Variância não paramétrica para o modelo com dois fatores, complementada com o teste de Dunn, usando a Mediana e os valores mínimos e máximos. O contraste pesquisado foi entre grupos e dentro dos momentos experimentais estudados, considerando-se $\mathrm{P}<0,05$. 
Os valores obtidos no exame morfométrico também foram transferidos para a Tabela Excel e avaliados estatisticamente.

Para o estudo da pseudocápsula, utilizou-se a técnica de Análise de Variância não paramétrica para o modelo com três fatores, complementada com o teste de Dunn, usando a Mediana e os valores mínimos e máximos. O contraste foi entre grupos, o local de medida da pseudocápsula e dentro dos momentos experimentais estudados, considerando-se $\mathrm{P}<0,05$.

Para o estudo da inflamação e do colágeno (Picrosirius Red), utilizou-se a técnica de Análise de Variância não paramétrica para o modelo com dois fatores, complementada com o teste de Dunn, usando a Mediana e os valores mínimos e máximos. O contraste foi entre grupos e dentro dos momentos experimentais estudados, considerando-se $\mathrm{P}<0,05$. 


\section{4 - RESULTADOS}

\section{Avaliação clínica dos animais dos diversos grupos experimentais}

\subsection{Avaliação da região órbito-palpebral}

- Todos os dias, pela manhã, os coelhos foram observados, sendo feita a higiene das suas pálpebras e conjuntiva, utilizando soro fisiológico $0,9 \%$ e algodão. Primeiramente removia-se as secreções que se encontravam acoladas aos pêlos, seguida da remoção da secreção do saco conjuntival e das crostas aderidas às margens palpebrais. Os animais não foram anestesiados para tal tarefa, não demonstrando dor a manipulação.

- Alguns coelhos apresentaram maior quantidade de secreção que os demais, sendo nos mesmos repetida à limpeza no período da tarde. Esta secreção era esbranquiçada e não tinha aspecto infeccioso e esteve presente em 7 coelhos, todos pertencentes ao momento M3 e distribuídos segundo os grupos:

o Grupo A: dois coelhos (nº 09 e 23)

o Grupo B: três coelhos (n² 24, 37 e 43)

o Grupo C: dois coelhos (n 16 e 21$)$ 


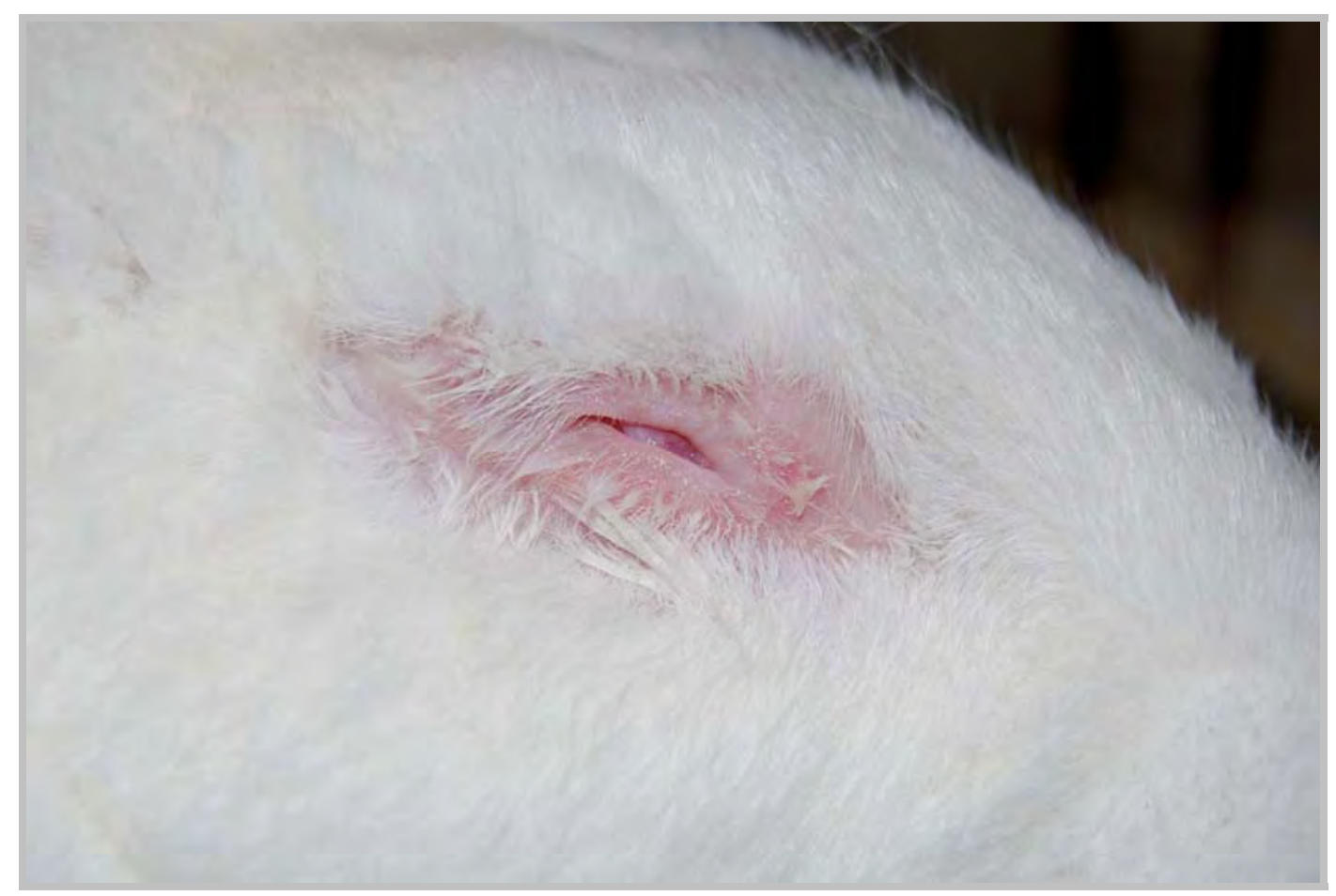

Figura 15: Aspecto da cavidade anoftálmica de coelho após sete dias (M1) de evisceração do olho direito. Observar a ausência de pelos na região adjacente à fenda palpebral e a escassez de sinais inflamatórios.

- Nenhum animal apresentou hiperemia conjuntival, deiscência ou extrusão do implante durante todo o seguimento do estudo.

\subsection{Evolução clínica sistêmica}

- A maioria dos animais evolui bem, alimentando-se normalmente e com atividade normal na gaiola;

- Foram a óbito oito animais: a) dois coelhos pareciam estar bem durante o acompanhamento; porém, vieram a morrer de forma súbita (coelhos $n^{\circ} 24$ pertencente ao grupo $\mathrm{B}$ e $\mathrm{n}^{\circ} 26$ pertencente ao grupo C, com 4 meses de acompanhamento). Ambos apresentavam evidências de queimadura na face, o que interpretamos ser possível ter ocorrido quando da limpeza das gaiolas, já que as 
mesmas são suspensas, sendo a limpeza feita usando fogo que queima os pelos que caíram dos animais. Portanto, o cuidado inadequado com a limpeza da gaiola pode ter causado queimaduras na face e até quadros respiratórios, provocando a morte destes dois animais. Esta rotina passou a ser revista pelos bioteristas depois do ocorrido; b) dois outros animais vieram a morrer por diarréia (coelhos $n^{\circ} 42$ pertencente ao grupo $\mathrm{C}$ aos 3 meses de acompanhamento e $\mathrm{n}^{\circ} 5$ pertencente ao grupo A, com 5 meses de acompanhamento); c) um coelho (Grupo B) apresentou uma lesão retro-orbital que não comprometeu o estado geral do coelho e apareceu ao $30^{\circ}$ dia de acompanhamento. Este coelho evoluiu bem, sem apresentar prostração e com deslocamento superior do posicionamento do implante, mas sem deiscência ou extrusão. Ao $60^{\circ}$ dia de acompanhamento esta lesão drenou uma secreção esbranquiçada da qual foi realizado exame histológico que demonstrou grande quantidade de células inflamatórias e atípicas. A partir deste momento este coelho não apresentou mais nenhuma alteração, a prótese retornou a posição normal e a cavidade não apresentava nenhuma alteração ao exame clínico. Ao $107^{\circ}$ dia de acompanhamento este coelho amanheceu morto, sem causa aparente. d) três outros animais foram encontrados mortos na gaiola, sem que tivesse algum fator que levantasse suspeita sobre a saúde geral dos mesmos (coelho $\mathrm{n}^{\circ} 21$ do grupo $\mathrm{C}$ com 5 meses e 24 dias de acompanhamento; coelho $\mathrm{n}^{\circ} 06$ do grupo $\mathrm{C}$ com 5 meses de acompanhamento; coelho $\mathrm{n}^{\circ} 32$ do grupo A com 5 meses e 26 dias de acompanhamento). Estes últimos animais faleceram em dias muito frios, juntamente com outros que se encontravam em seguimento na mesma sala e que pertenciam a outros estudos, levantando a hipótese de alterações atmosféricas, levando a doenças comuns e provocando o óbito. 
- Desta forma, segundo a observação clínica, pode-se dizer que nenhum animal apresentou alterações sistêmicas que fossem decorrentes da cirurgia ou dos cones.

- Alguns animais apresentaram perda de pelos na região periorbital, sem sinais inflamatórios e sem comprometimento da cavidade eviscerada, que mantinha-se sem hiperemia e excelente cicatrização (coelho n 11 - Grupo A, M2; coelho ${ }^{\circ}$ 03Grupo B, M3; coelho n 36- Grupo C, M2).

- Todos os animais que evoluíram para óbito foram substituídos, permanecendo o estudo com o mesmo número de coelhos idealizados no projeto de pesquisa inicial.

\subsection{Peso dos animais}

O peso inicial dos animais dos diferentes grupos experimentais era semelhante, não tendo sido observada diferença estatística entre os grupos (Tabela 3).

Tabela 3. Média e desvio padrão do peso inicial (em gramas) dos coelhos, segundo grupo experimental.

\begin{tabular}{c|c|c|c}
\hline Grupo A & Grupo B & Grupo C & Valor P \\
\hline $2064,5 \pm 447,9$ & $2314,4 \pm 293,0$ & $2008,1 \pm 298,1$ & $\mathrm{P}>0,005$ \\
\hline
\end{tabular}

Os animais do estudo apresentaram ganho de peso em todos os grupos com o passar do tempo, sendo este aumento significativo estatisticamente. Entre os grupos houve uma diferença estatística entre o grupo B e C no momento 1 (M1), porém sem significado clínico (tabela 4). 
Tabela 4. Média e desvio padrão do peso de coelhos segundo grupo e momento de sacrifício.

\begin{tabular}{cccc}
\hline \multirow{2}{*}{ Grupo } & \multicolumn{3}{c}{ Momento } \\
\cline { 2 - 4 } & & M1 & M3 \\
\hline A & $2566,8 \pm 434,6$ & $3974,8 \pm 131,3^{\Delta}$ & $5115,4 \pm 129,7^{\#}$ \\
\hline B & $2902,0 \pm 339,5^{*}$ & $3974,4 \pm 416,9^{\Delta}$ & $5106,7 \pm 201,0^{\#}$ \\
\hline C & $2179,6 \pm 359,5$ & $3685,6 \pm 285,1^{\Delta}$ & $4988,0 \pm 194,9^{\#}$ \\
\hline$*(p<0,05)$ B x C & & & \\
${ }^{*}(\mathrm{p}<0,05)$ M3 x (M2 e M1) & & & \\
${ }_{(\mathrm{p}<0,05)}$ M2 x M1 & & & \\
\hline
\end{tabular}

\section{Exames Bioquímicos}

Os exames bioquímicos, colhidos antes do procedimento cirúrgico e antes da eutanásia, possibilitaram comparação dos valores obtidos no início do estudo e no seu final, mostrando que todos os animais apresentavam-se com saúde equivalente ao seu estado de antes das manipulações experimentais.

Os valores obtidos antes do procedimento cirúrgico constam da primeira coluna (M0). Os resultados referentes aos exames colhidos imediatamente antes do sacrifício estão apresentados segundo grupo de animais (A, B, C), dentro dos respectivos momentos experimentais (M1, M2, M3). Alguns resultados estão apresentados segundo Média e desvio-padrão (Creatinina e Uréia) e outros pela Mediana e semi-amplitude total, devido ao padrão de resposta ocorrido com a variável de estudo e necessidade de aplicação do tipo de teste estatístico. 
Ressalte-se que, para todos os parâmetros bioquímicos estudados, embora tenham sido observadas algumas diferenças estatísticas, os valores observados estiveram sempre dentro dos limites de normalidade considerados para a espécie.

Os resultados que refletem a função renal, representados pelos exames de Uréia e Creatinina passam a ser relatados. A Uréia não apresentou diferença entre os grupos e nem entre os momentos do estudo. Já o estudo da Creatinina, mostrou que houve alteração significativa entre os grupos B e C, sendo observado valor menor no momento inicial (M0). Ainda nos resultados da Creatinina houve aumento dos seus valores nos momentos M1, M2 e M3 em relação ao momento inicial (M0) nos grupos A e B, e entre os momentos M2 e M3 com os momentos M0 e M1 no grupo C (tabela 5).

Tabela 5. Média e desvio padrão das dosagens bioquímicas da Uréia e Creatinina de coelhos submetidos à evisceração do olho direito e colocação de cones na cavidade anoftálmica, segundo grupo e momento de avaliação.

Momento de Avaliação

\begin{tabular}{|c|c|c|c|c|c|}
\hline & Grupo & MO & M1 & M2 & M3 \\
\hline \multirow{3}{*}{ Uréia } & A & $35,465 \pm 9,782$ & $37,260 \pm 8,124$ & $42,260 \pm 6,042$ & $36,342 \pm 8,171$ \\
\hline & B & $41,433 \pm 12,757$ & $31,100 \pm 3,486$ & $43,060 \pm 8,525$ & $36,225 \pm 5,314$ \\
\hline & $\mathrm{C}$ & $38,773 \pm 12,641$ & $28,700 \pm 6,195$ & $37,900 \pm 4,721$ & $36,140 \pm 9,693$ \\
\hline \multirow{3}{*}{ Creatinina } & A & $1,006 \pm 0,244^{\#}$ & $1,340 \pm 0,305$ & $1,500 \pm 0,367$ & $1,586 \pm 0,267$ \\
\hline & B & $1,039 \pm 0,289 *^{\#}$ & $1,320 \pm 0,164$ & $1,520 \pm 0,228$ & $1,587 \pm 0,173$ \\
\hline & $\mathrm{C}$ & $0,827 \pm 0,194^{\Delta}$ & $1,000 \pm 0,100^{\Delta}$ & $1,500 \pm 0,200$ & $1.500 \pm 0,235$ \\
\hline \multicolumn{6}{|c|}{$*(\mathrm{P}<0,05) \mathrm{B} \times \mathrm{C}$} \\
\hline \multicolumn{6}{|c|}{${ }^{\#}(\mathrm{P}<0,05) \mathrm{M} 0 \mathrm{x}(\mathrm{M} 1, \mathrm{M} 2, \mathrm{M} 3)$} \\
\hline \multicolumn{6}{|c|}{${ }^{\Delta}(\mathrm{P}<0,05)(\mathrm{M} 0, \mathrm{M} 1) \times(\mathrm{M} 2, \mathrm{M} 3)$} \\
\hline
\end{tabular}


Para a pesquisa da função hepática dos coelhos, no momnento inicial (M0) em todos os momentos de sacrifício (M1, M2, M3), foram feitas dosagens de TGO, TGP, FA e LDH.

A TGO (aspartato aminotransferase) não apresentou diferenças estatísticas entre os grupos e momentos do estudo (tabela 6).

Tabela 6. Mediana e valores máximo e mínimo das dosagens bioquímicas da TGO de coelhos submetidos à evisceração do olho direito e colocação de cones na cavidade anoftálmica, segundo grupo e momento de avaliação.

\begin{tabular}{|c|c|c|c|c|c|}
\hline \multicolumn{6}{|c|}{ Momento de Avaliação } \\
\hline & Grupo & M0 & M1 & M2 & M3 \\
\hline \multirow{3}{*}{ TGO } & A & $18,0(14,0 ; 47,0)$ & $17,3(16,2 ; 27,7)$ & $14,1(12,0 ; 28,3)$ & $20,4(15,0 ; 43,0)$ \\
\hline & B & $20,5(14,0 ; 47,0)$ & $22,0(7,9 ; 50,3)$ & $24,6(13,6 ; 38,7)$ & $25,1(14,1 ; 38,0)$ \\
\hline & $\mathrm{C}$ & $18,0(8,0 ; 39,0)$ & 18,3 (2,6; 33,5) & $18,3(11,0 ; 27,7)$ & $18,0(3,1 ; 25,2)$ \\
\hline
\end{tabular}

$\mathrm{TGO}=$ aspartato aminotransferase

Nos exames de TGP (alanina aminotransferase) houve diferença estatística no grupo A, entre o momento M3 e o momento M0 e M2, e no grupo B entre o Momento 3 e Momento 2, sendo que os valores encontrados foram menores no M3 em relação aos outros momentos. No grupo C não houve diferença estatística (tabela 7). 
Tabela 7. Mediana e valores máximo e mínimo das dosagens bioquímicas da TGP de coelhos submetidos à evisceração do olho direito e colocação de cones na cavidade anoftálmica, segundo grupo e momento de avaliação.

\begin{tabular}{cccccc}
\hline \multicolumn{5}{c}{ Momento de Avaliação } \\
\hline & Grupo & M0 & M1 & M2 & M3 \\
\hline & A & $16,0(5,0 ; 34,0)$ & $12,0(5,0 ; 15,0)$ & $20,0(17,0 ; 85,0)$ & $5,0(4,0 ; 7,0)^{*}$ \\
\cline { 2 - 6 } TGP & B & $17,5(5,0 ; 30,0)$ & $15,0(7,0 ; 19,0)$ & $24,0(21,0 ; 36,0)$ & $7,0(3,0 ; 28,0) \#$ \\
\cline { 2 - 5 } & & & & & \\
\hline
\end{tabular}

TGP= alanina aminotransferase

* $(\mathrm{P}<0,05)$ M3 x (M0, M1)

${ }^{\#}(\mathrm{P}<0,05) \mathrm{M} 3 \mathrm{x}$ M2

Nas dosagens da FA (Fosfatase Alcalina),, os resultados encontrados entre os grupos, só foi estatisticamente significativo entre o grupo A e C no momento M1, sendo o valor da fosfatase alcalina maior em A. Em relação aos momentos de análise: no grupo A, o valor da FA diminui em M3 em relação aos momentos M0 e M1; no grupo B, o valor diminui em M3 em relação aos momentos M0, M1 e M2; no grupo C, o valor é maior no M0 em relação aos outros três momentos (tabela 8). 
Tabela 8. Mediana e valores máximo e mínimo das dosagens bioquímicas da fosfatase alcalina de coelhos submetidos à evisceração do olho direito e colocação de cones na cavidade anoftálmica, segundo grupo e momento de avaliação.

\begin{tabular}{|c|c|c|c|c|c|}
\hline \multicolumn{6}{|c|}{ Momento de Avaliação } \\
\hline & Grupo & MO & M1 & M2 & M3 \\
\hline \multirow{3}{*}{ FA } & $\mathrm{A}$ & $131,2(64,8 ; 198,8)$ & $172,5(127,2 ; 273,3)^{*}$ & $85,9(54,3 ; 196,0)$ & $26,7(17,0 ; 58,3) \#$ \\
\hline & $\mathrm{B}$ & $105,3(72,1 ; 222,8)$ & $147,4(122,3 ; 165,2)$ & 115,0 (52,6; 118,3) & $25,9(20,3 ; 43,7) \Delta$ \\
\hline & $\mathrm{C}$ & $112,6(74,5 ; 194,4) \alpha$ & $98,8(90,7 ; 119,9)$ & $67,2(55,9 ; 97,2)$ & $30,8(27,5 ; 99,6)$ \\
\hline
\end{tabular}

$\mathrm{FA}=$ fosfatase alcalina

$*(\mathrm{P}<0,05) \mathrm{A} \times \mathrm{C}$

${ }^{\#}(\mathrm{P}<0,05) \mathrm{M} 3 \times(\mathrm{M} 0, \mathrm{M} 1)$

$\Delta(\mathrm{P}<0,05) \mathrm{M} 3 \times(\mathrm{M} 0, \mathrm{M} 1, \mathrm{M} 2)$

$\alpha(\mathrm{P}<0,05) \mathrm{M} 0 \mathrm{x}(\mathrm{M} 1, \mathrm{M} 2, \mathrm{M} 3)$

Nos resultados do exame de LDH não houve diferença estatística entre os valores ao avaliar os diferentes grupos experimentais. No grupo A, no M1 houve uma redução do valor encontrado em relação ao outros momentos (M0, M2 e M3) (tabela 9). 
Tabela 9. Mediana e valores máximo e mínimo das dosagens bioquímicas da LDH de coelhos submetidos à evisceração do olho direito e colocação de cones na cavidade anoftálmica, segundo grupo e momento de avaliação.

\begin{tabular}{|c|c|c|c|c|c|}
\hline \multicolumn{6}{|c|}{ Momento de Avaliação } \\
\hline & Grupo & M0 & M1 & M2 & M3 \\
\hline \multirow{3}{*}{$\mathrm{LDH}$} & A & $72,8(\quad)$ & $12,1(10,0 ; 58,2)^{*}$ & $70,0(39,0 ; 502,0)$ & $72,8(10,0 ; 349,5)$ \\
\hline & $\mathrm{B}$ & $98,3(9,7 ; 267,6)$ & $17,4(9,0 ; 385,9)$ & $148,0(21,8 ; 446,6)$ & $142,0(70,4 ; 216,0)$ \\
\hline & $\mathrm{C}$ & $106,8(9,7 ; 300,9)$ & $58,2(12,1 ; 148,0)$ & $194,2(24,3 ; 497,5)$ & $114,1(63,1 ; 325,2)$ \\
\hline
\end{tabular}

LDH: desidrogenase láctea

* $(\mathrm{P}<0,05) \mathrm{M} 1$ x $(\mathrm{M} 0, \mathrm{M} 1, \mathrm{M} 3)$

Na pesquisa do exame de função cardíaca foi realizado baseando-se nos valores observados para a creatinofosfoquinase (CPK), tendo ocorrido redução do valor estatisticamente significativo, no Grupo A no M3 em relação ao M2. Entre os grupos A, B e C e no restante dos momentos, não houve diferença estatística (tabela 10). 
Tabela 10. Mediana e valores máximo e mínimo das dosagens bioquímicas da CPK de coelhos submetidos à evisceração do olho direito e colocação de cones na cavidade anoftálmica, segundo grupo e momento de avaliação.

\begin{tabular}{|c|c|c|c|c|c|}
\hline \multicolumn{6}{|c|}{ Momento de Avaliação } \\
\hline & Grupo & M0 & M1 & M2 & M3 \\
\hline \multirow{3}{*}{ CPK } & A & $786,0(307,9 ; 1501,0)$ & $460,8(278,5 ; 648,2)$ & $790,0(351,4 ; 1745,0)$ & $448,7(234,0 ; 768,7)^{*}$ \\
\hline & B & $573,0(205,6 ; 1336,0)$ & $460,8(278,5 ; 648,2)$ & $548,9(342,3 ; 1629,0)$ & $389,4(261,3 ; 1239,0)$ \\
\hline & C & $666,4(380,0 ; 2020,0)$ & $647,2(372,7 / 713,0)$ & $781,0(371,7 ; 1050,0)$ & $544,9(298,8 ; 1077,0)$ \\
\hline \multicolumn{6}{|c|}{$\mathrm{CPK}=$ creatinoquinase } \\
\hline
\end{tabular}

\section{Avaliação Histológica}

O cone não estava presente em todas as lâminas estudadas, uma vez que este foi removido para a confecção das mesmas, devido à impossibilidade de partir o biomaterial. Sendo assim, as lâminas foram avaliadas na porção interna, local em que havia a relação direta da esclera com o cone, porém sem a presença deste.

Ao exame macroscópico das lâminas observou-se que mesmo com a retirada do cone da capa escleral, o material permaneceu com a forma cônica.

As observações foram feitas em todos os animais que compuseram a amostra e estão descritas separadas por momento do estudo. 


\section{1 - Observações Histológicas feitas em M1}

\subsubsection{Grupo A}

Após sete dias do procedimento de evisceração com a colocação dos cones na cavidade anoftálmica (M1), na interface entre a parte interna da esclera e a externa do material estudado, observou-se tecido necrótico e a formação de tecido regenerativo, composto por uma rede de fibrina contendo células de formato fusiforme e de núcleo arredondado, compatível com morfologia de fibroblastos jovens, além de hemácias, células inflamatórias (principalmente neutrófilos) em meio à rede de fibrina e edema, quadro correspondente a inflamação do tipo aguda (figura 16A). Pequenos fragmentos do biomaterial, assim como alguns neovasos, foram observados em meio à reação tecidual. A esclera apresentava-se edemaciada, principalmente na porção anterior, nos locais coincidentes com a sutura esclero-escleral. O fio de sutura estava presente e ao redor do mesmo a reação inflamatória era mais acentuada.

Neste momento já era possível observar a formação da pseudocápsula, composta por acúmulo de fibroblastos e células inflamatórias, dispostos de maneira circular e a envolver a maior parte da porção interna da capa escleral.

\subsubsection{Grupo B}

A resposta regenerativa tecidual presente neste momento foi semelhante ao que se observou no Grupo A no momento 1, ou seja, revestindo a face interna da capa escleral havia aglomerado de células inflamatórias e hemácias em meio à rede de 
fibrina. O processo inflamatório em alguns lugares foi mais intenso, observando-se na coloração de HE, grumos de intensa coloração roxa, correspondendo ao acúmulo de células necróticas (Figura 16B). Em alguns lugares, notou-se a presença de birrefringência, localizada na superfície interna da esclera e permeando a resposta reparativa.

\subsubsection{Grupo C}

A análise histológica deste grupo mostra que o processo reparativo foi semelhante ao que o ocorreu nos demais grupos, em especial ao grupo B (Figura 16C). 


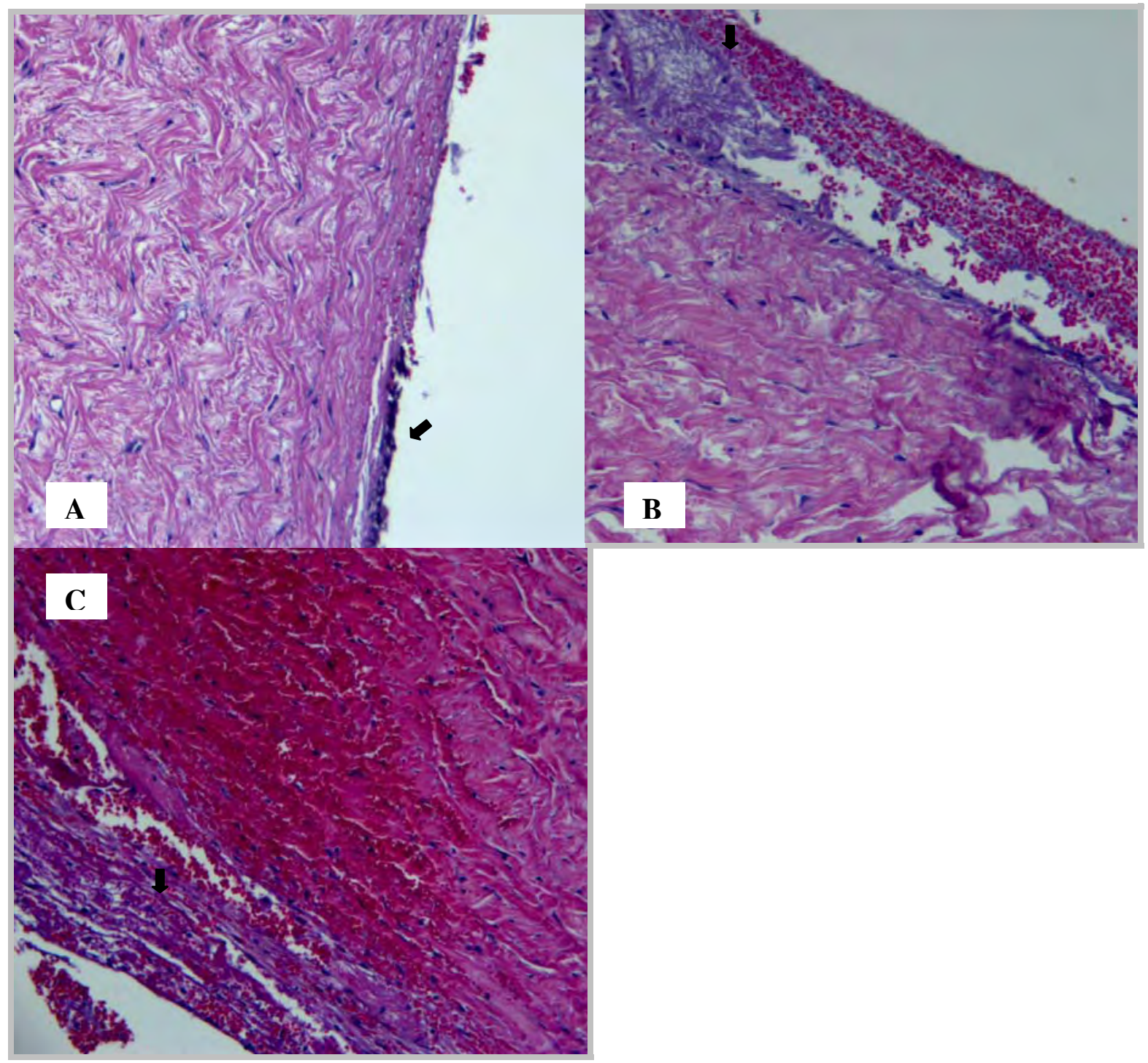

Figura 16. Cortes histológicos referentes à reação de reparação tecidual formada entre a esclera e os cones no M1 (seta). A) Biovidro. B) Biovitrocerâmico I. C) Biovitrocerâmico II. Em todos os cortes nota-se a pseudocápsula, formada por fibroblastos, hemácias e células inflamatórias( HE 40X ). 


\subsection{Observações Histológicas feitas em M2}

\subsubsection{Grupo A}

Após 90 dias do procedimento de evisceração com a colocação dos cones na cavidade anoftálmica (M2), na interface entre a parte interna da esclera e a externa do material estudado havia menor quantidade de células inflamatórias. A pseudocápsula apresentava-se mais densa, composta por fibroblastos contendo núcleos menores que os observados em M1, estando aparentemente menos espessa e com menor quantidade de hemácias e de edema tecidual (figura 17A). Presença de neovasos contendo hemácias.

\subsubsection{Grupo B}

As características descritas para o grupo A se repetiram no grupo B (figura 17B).

\subsubsection{Grupo C}

As características descritas para o grupo A e B se repetiram no grupo C (figura 17C). 


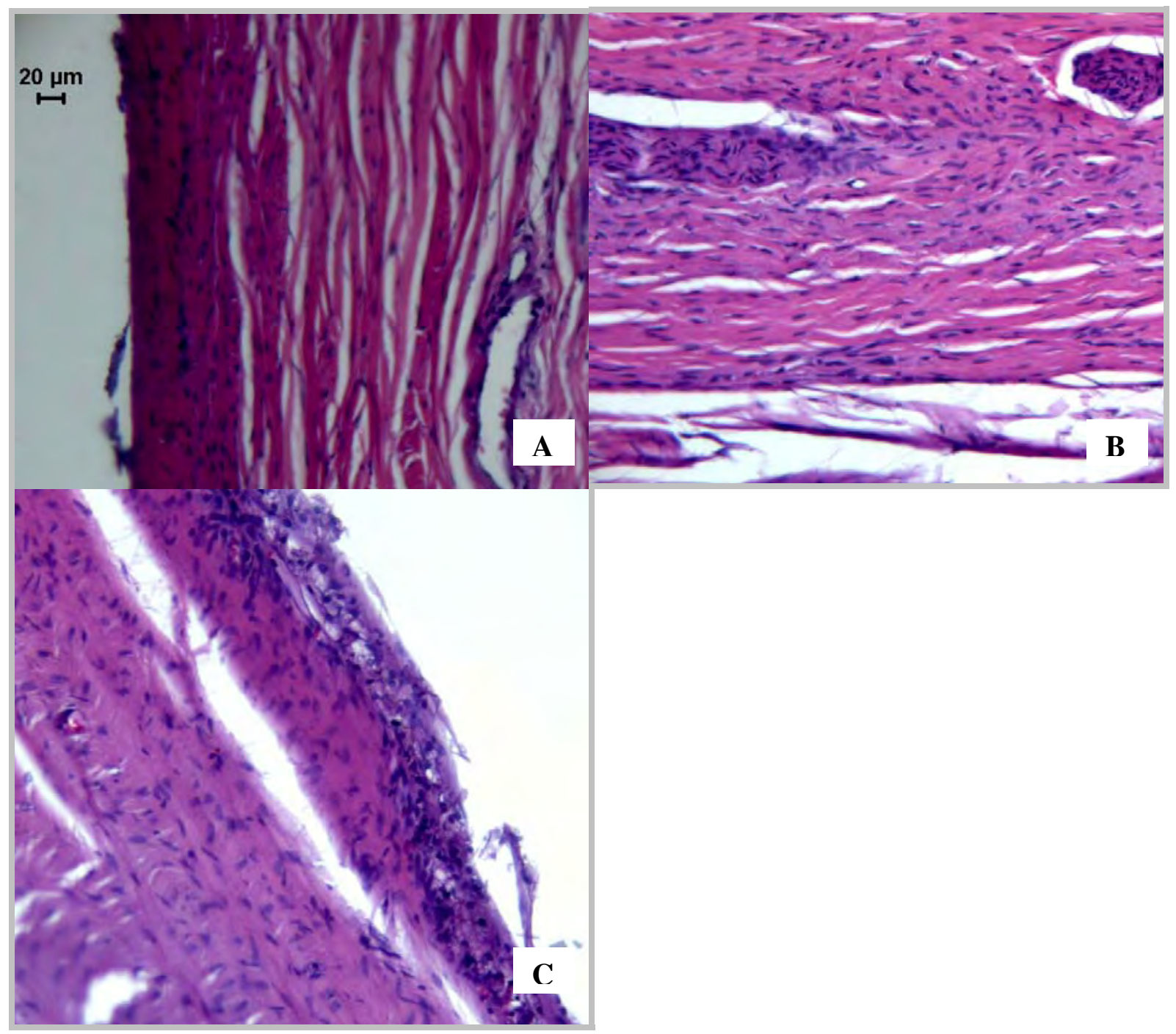

Figura 17. Cortes histológicos referentes à reparação tecidual formada entre a esclera e os cones no M2. A) Biovidro. B) Biovitrocerâmico I. C) Biovitrocerâmico II. Nota-se a pseudocápsula menos espessa, principalmente no grupo A (HE 40X). 


\subsection{Observações Histológicas feitas em M3}

\subsubsection{Grupo A}

Após 180 dias do procedimento de evisceração com a colocação dos cones na cavidade anoftálmica (M3), na interface entre a parte interna da esclera e a externa do material estudado, não se observava mais o edema; presença de neovasos contendo hemácias. Reação inflamatória escassa (Figura 18A). Os fragmentos do biovidro encontravam-se envoltos pelo tecido conjuntivo reparativo, com ausência de reação inflamatória, identificados como áreas de birrefringência.

\subsubsection{Grupo B}

As características descritas para o Grupo A se repetiram no Grupo B (figura 18B).

\subsubsection{Grupo C}

As características descritas para o Grupo A e B se repetiram no Grupo C(figura 18C). 


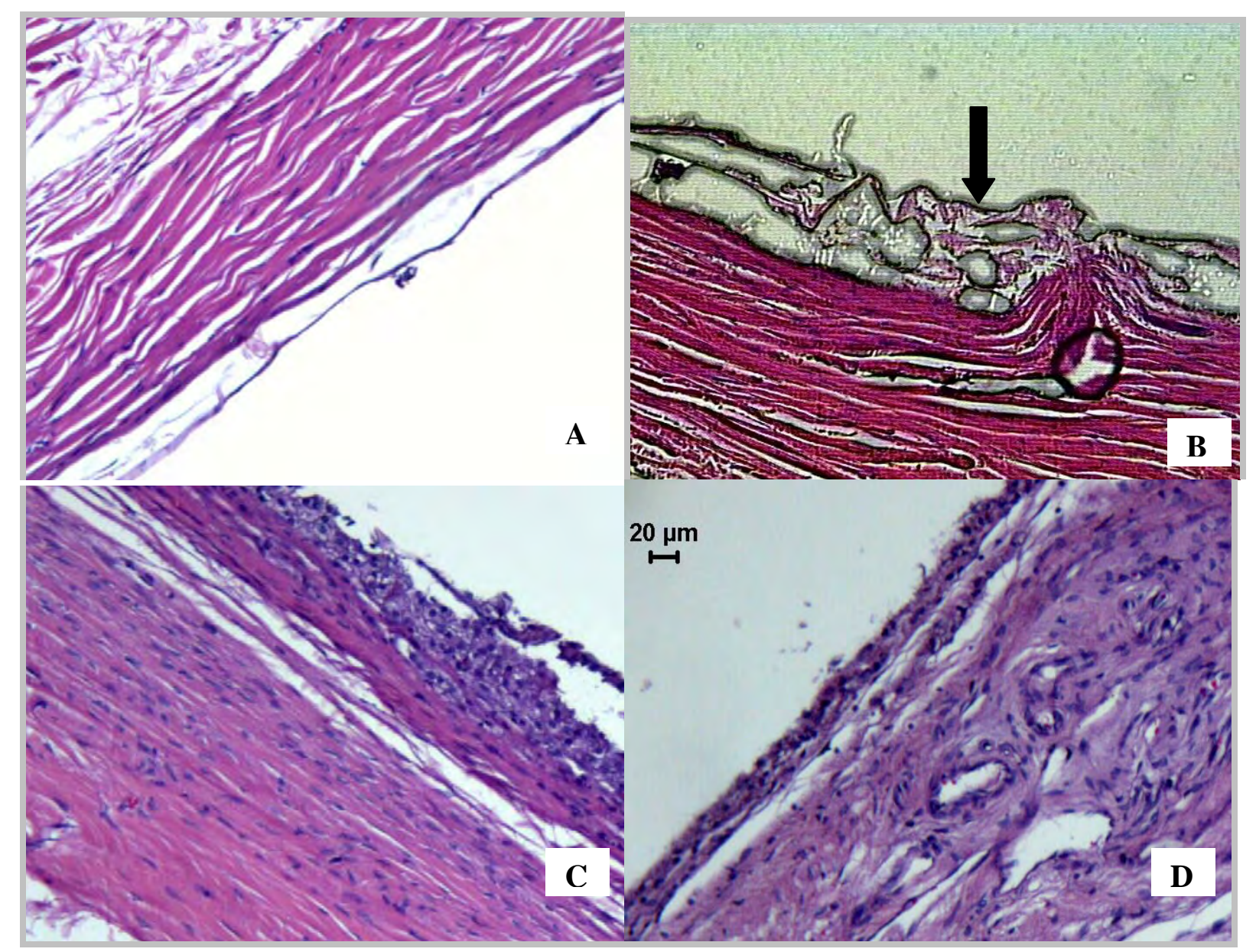

Figura 18: Cortes histológicos referentes à reparação tecidual entre a esclera dos coelhos e os cones no momento 3 (M3).. A) Biovidro. B) Presença do biomaterial (seta) envolto por tecido reparativo do hospedeiro C) Biovitrocerâmico. D) Biovitrocerâmico II. Nota-se pseudocápsula formada por fibroblastos, ausência de edema e pequena reação inflamatória (HE 40X).

\subsection{Resultados do exame morfométrico}

\subsubsection{Avaliação da espessura da pseudocápsula}

A avaliação da espessura da pseudocápsula que se formou ao redor dos cones está apresentada na tabela 11.

No grupo A, a avaliação da espessura da pseudocápsula mostrou-se maior em M1 em relação aos momentos M2 e M3, na posição chamada de 9 horas. O mesmo ocorreu no grupo B, na posição anterior e posterior, e no grupo C, na posição posterior. 
Na região anterior, a pseudocápsula encontrou-se mais espessa no grupo B em M1 e no grupo C, em M3.

Ao comparar os biomateriais, o grupo C apresentou a pseudocápsula mais espessa em M1 na região denominada posterior e em M3, na anterior e às 9h, quando comparado aos grupos A e B.

No M1, nas posições posterior e 3 horas, a espessura da pseudocápsula foi maior nos Grupos B e C, quando comparados com o Grupo A.

Apesar de não se ter observado diferença estatística significativa para a maioria das comparações entre os grupos A, B e C, houve uma tendência de valores menores para a espessura da pseudocápsula nos animais do Grupo A, os que receberam o biovidro, em todos os locais de medição (anterior, posterior, 3horas e 9horas). 
Tabela 11. Mediana e valores máximo e mínimo referentes à espessura da pseudocápsula formada entre a esclera e os cones, em cavidades evisceradas de coelhos, segundo grupo, momento de avaliação e região onde foi realizada a observação.

\begin{tabular}{|c|c|c|c|c|}
\hline \multirow[t]{2}{*}{ Grupo } & \multirow[t]{2}{*}{ Região } & \multicolumn{3}{|c|}{ Momento } \\
\hline & & M1 & M2 & M3 \\
\hline \multirow{4}{*}{ A } & Anterior & 21,945 (12,397; 37,596) & $10,833(4,714 ; 25,710)$ & $18,828(11,209 ; 35,136)$ \\
\hline & Posterior & 20,230 (10,292; 23,320) & $12,730(7,004 ; 19,503)$ & $15,652(8,522 ; 19,007)$ \\
\hline & 3 horas & $18,282(13,444 ; 23,797)$ & $10,222(6,451 ; 20,041)$ & $12,451(10,735 ; 32,262)$ \\
\hline & 9 horas & 25,206 (20,693; 51,633)* & $14,481(5,358 ; 19,485)$ & $13,792(10,537 ; 30,120)$ \\
\hline \multirow{4}{*}{$\mathbf{B}$} & Anterior & $93,854(23,634 ; 108,932)^{* \# \alpha}$ & $12,746(5,533 ; 30,881)$ & $14,948(10,419 ; 21,911)$ \\
\hline & Posterior & $49,759(18,125 ; 59,581)^{*}$ & $12,836(7,036 ; 60,532)$ & $17,456(9,993 ; 44,070)$ \\
\hline & 3 horas & $15,094(11,974 ; 65,345)^{\alpha}$ & $22,132(10,312 ; 28,586)$ & 19,446 (12,899; 73,155) \\
\hline & 9 horas & 30,894 (18,155; 47,194)* & 12,235 (9,134; 27,000) & $16,236(14,223 ; 31,315)$ \\
\hline \multirow{4}{*}{$\mathbf{C}$} & Anterior & $47,138(24,291 ; 128,852)$ & 20,341 (10.090; 67,763) & 73,796 (20,112; 126,212) $)^{\# \Delta}$ \\
\hline & Posterior & $51,970(34,444 ; 137,236)^{* \Delta}$ & 19,397 (6,833; 47,915) & $17,075(12,158 ; 48,799)$ \\
\hline & 3 horas & $35,644(13,905 ; 51,501)$ & 16,371 (5,147; 43,442) & $23,530(17,135 ; 37,503)$ \\
\hline & 9 horas & 37, $538(13,861 ; 235,228)$ & $17,343(5,593 ; 40,870)$ & $33,352(10,059 ; 40,795)^{\Delta}$ \\
\hline \multicolumn{5}{|c|}{$*(\mathrm{P}<0,05) \mathrm{M} 1$ x $(\mathrm{M} 2, \mathrm{M} 3)$} \\
\hline \multicolumn{5}{|c|}{ \# $(\mathrm{P}<0,05)$ Anterior x (Posterior, 3h, 9h) } \\
\hline \multicolumn{5}{|c|}{${ }^{\Delta}(\mathrm{P}<0,05) \mathrm{C} x(\mathrm{~A}, \mathrm{~B})$} \\
\hline$\alpha$ & & & & \\
\hline
\end{tabular}

\subsubsection{Avaliação da celularidade existente na pseudocápsula}

A avaliação da celularidade observada na pseudocápsula que se formou ao redor dos cones está apresentada na Tabela 12.

Quanto à celularidade, quando se compara os momentos dentro de cada grupo, observa-se redução significativa da quantidade de células inflamatórias de M1 para M2 e M3. Observou-se, ainda, a inflamação mais importante nos implantes do Grupo C (biovitrocerâmico II) no M1 em relação aos Grupos A e B. 
Tabela 12. Mediana e valores máximo e mínimo referentes à celularidade observada nos tecidos regenerativos formados entre a esclera e os cones, em cavidades evisceradas de coelhos, segundo grupo e momento de avaliação.

\begin{tabular}{cc|c|c}
\hline \multirow{2}{*}{ Grupo } & \multicolumn{3}{c}{ Momento } \\
\cline { 2 - 4 } & M1 & M2 & M3 \\
\hline A & $2+(1 ; 2)$ & $1+(1 ; 3)$ & $1+(1 ; 2)$ \\
\hline B & $2+(2 ; 2)$ & $2+(1 ; 3)$ & $1,5+(1 ; 2)$ \\
\hline C & $3+(3 ; 3)^{*} \#$ & $2+(1 ; 2)$ & $2+(1 ; 2)$ \\
$\#(P<0,05)$ C x (A,B) & & & \\
\hline
\end{tabular}

\subsubsection{Avaliação do colágeno}

Para análise da quantidade de colágeno existente nas pseudocápsulas, com os valores encontrados em cada lâmina foi calculada a média e o desvio padrão, nos momentos M1 e M3, analisadas e calculadas automaticamente pelo software de análise de imagens Image Pro-plus (figura 19).

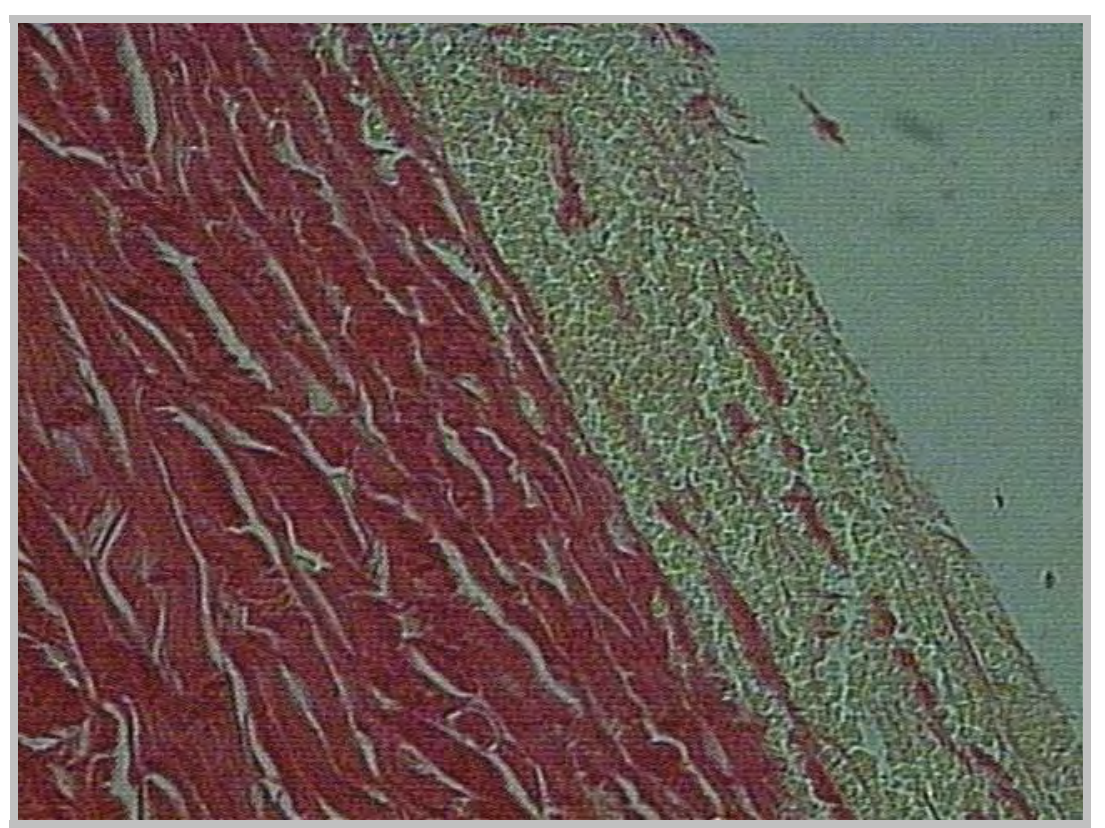

Figura 19. Corte histológico referente à reparação tecidual formada entre a esclera e os cones no Grupo A, em M1. As fibras colágenas coradas em vermelho; os miócitos em amarelo; e os espaços em branco. Picrosirius Red (PR 40X). 


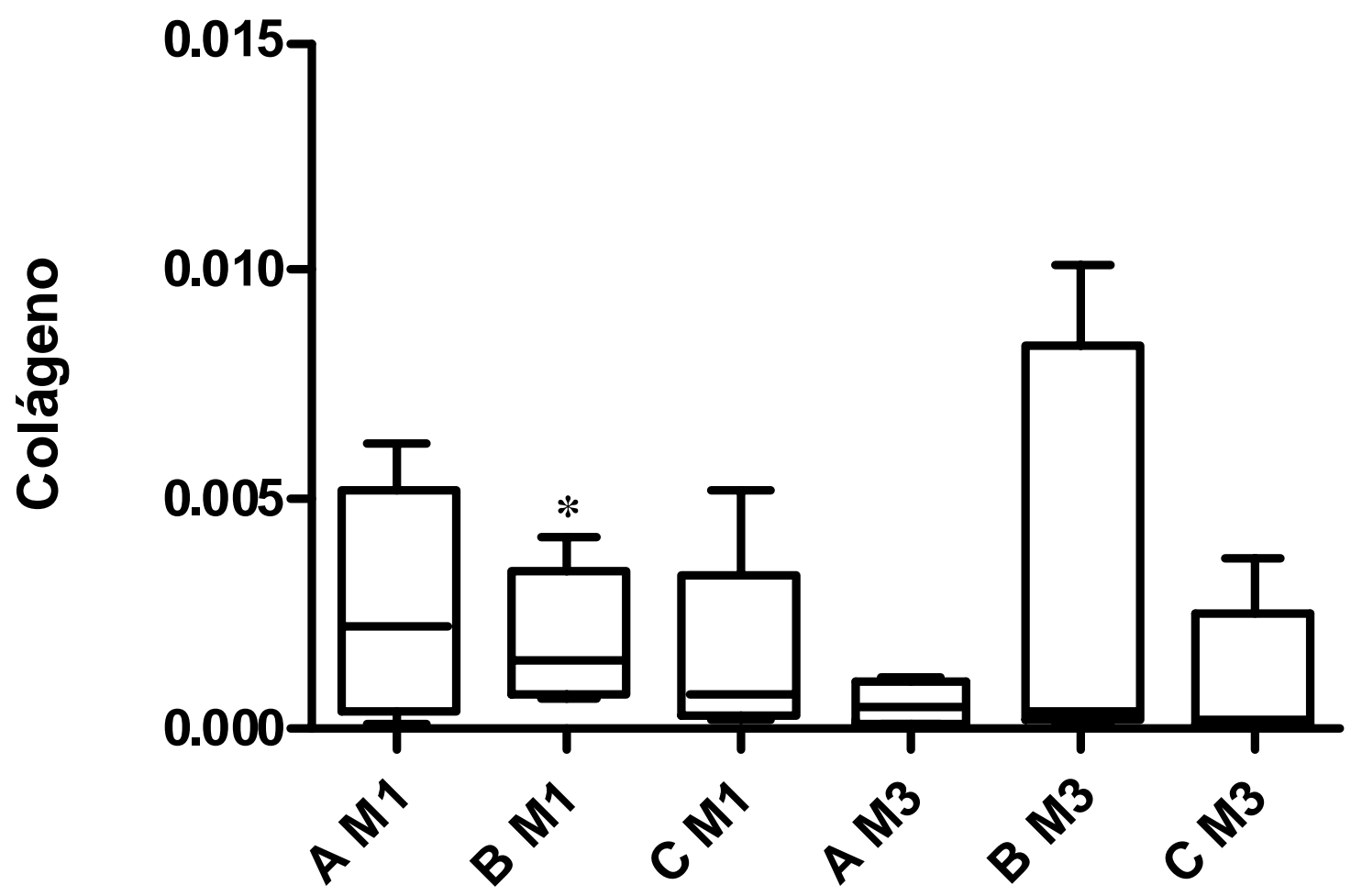

\section{Grupos e Momentos de avaliação}

Gráfico 1. Mediana, valores máximo e mínimo, da quantidade de colágeno encontrado na interface entre a esclera e os cones, segundo grupo e momentos de estudo.

A M1= grupo A e momento 1

$\mathrm{B}$ M1= grupo $\mathrm{B}$ e momento 1

$\mathrm{C}$ M1= grupo $\mathrm{C}$ e momento 1

A M3= grupo A e momento 3

$\mathrm{B}$ M3= grupo $\mathrm{B}$ e momento 3

$\mathrm{C}$ M3 $=$ grupo $\mathrm{C}$ e momento 3

$*(\mathrm{P}<0,05) \mathrm{M} 1>\mathrm{M} 3$

A avaliação dos valores médios observados nas medidas da quantidade de colágeno existente na pseudocápsula foi semelhante para os três grupos experimentais, tanto no momento M1, como no M3. Comparando-se os valores de cada grupo nos momentos M1 e M3, houve diferença estatística apenas no grupo B, quando a quantidade de colágeno foi maior no momento $\mathrm{M} 1$, tanto para a média quanto para o desvio padrão (Gráfico 1). 
A avaliação dos percentuais de colágeno encontrado na pseudocápsula dos três grupos estudados nos dois momentos de avaliação, mostrou que não havia diferença entre os grupos, tanto no momento M1, como no M3. Comparando-se os momentos fixando-se o grupo, a análise estatística mostrou que no grupo B os valores observados, foram maiores no M1 (Tabela 13).

Tabela 13. Porcentagem de colágeno avaliada no exame de lâminas coradas por Picrosirius Red segundo implante e momento, e seus valores máximo e mínimo.

\begin{tabular}{lccc}
\hline & Grupo & \multicolumn{2}{c}{ Momento de avaliação } \\
\cline { 3 - 4 } & & \multicolumn{1}{c}{ M1 } & \multicolumn{1}{c}{ M3 } \\
\hline \multirow{2}{*}{ Porcentagem } & A & $0,0618(0,0068 ; 0,3190)$ & $0,0101(0,0095 ; 0,812)$ \\
& B & $0,1670(0,0725 ; 0,4210)^{*}$ & $0,0283(0,0088 ; 0,7820)$ \\
& C & $0,0869(0,0298 ; 0,2690)$ & $0,0143(0,0033 ; 0,2100)$ \\
\hline
\end{tabular}

$*((\mathrm{P}<0,05) \mathrm{M} 1>\mathrm{M} 3$

\subsection{Avaliação Tomográfica}

A Tomografia Computadorizada, realizada nos coelhos com 45 dias pós cirurgia de evisceração e colocação dos cones, incluiu todos os animais dos momentos M2 e M3. Não houve nenhuma perda de animal em decorrência do ato anestésico ou por outro motivo durante este procedimento.

As imagens tomográficas foram avaliadas individualmente, em três dimensões, não tendo sido encontradas imagens sugestivas de coleção purulenta, de deslocamento ou ausência dos cones nas cavidades orbitárias (figura 20). 


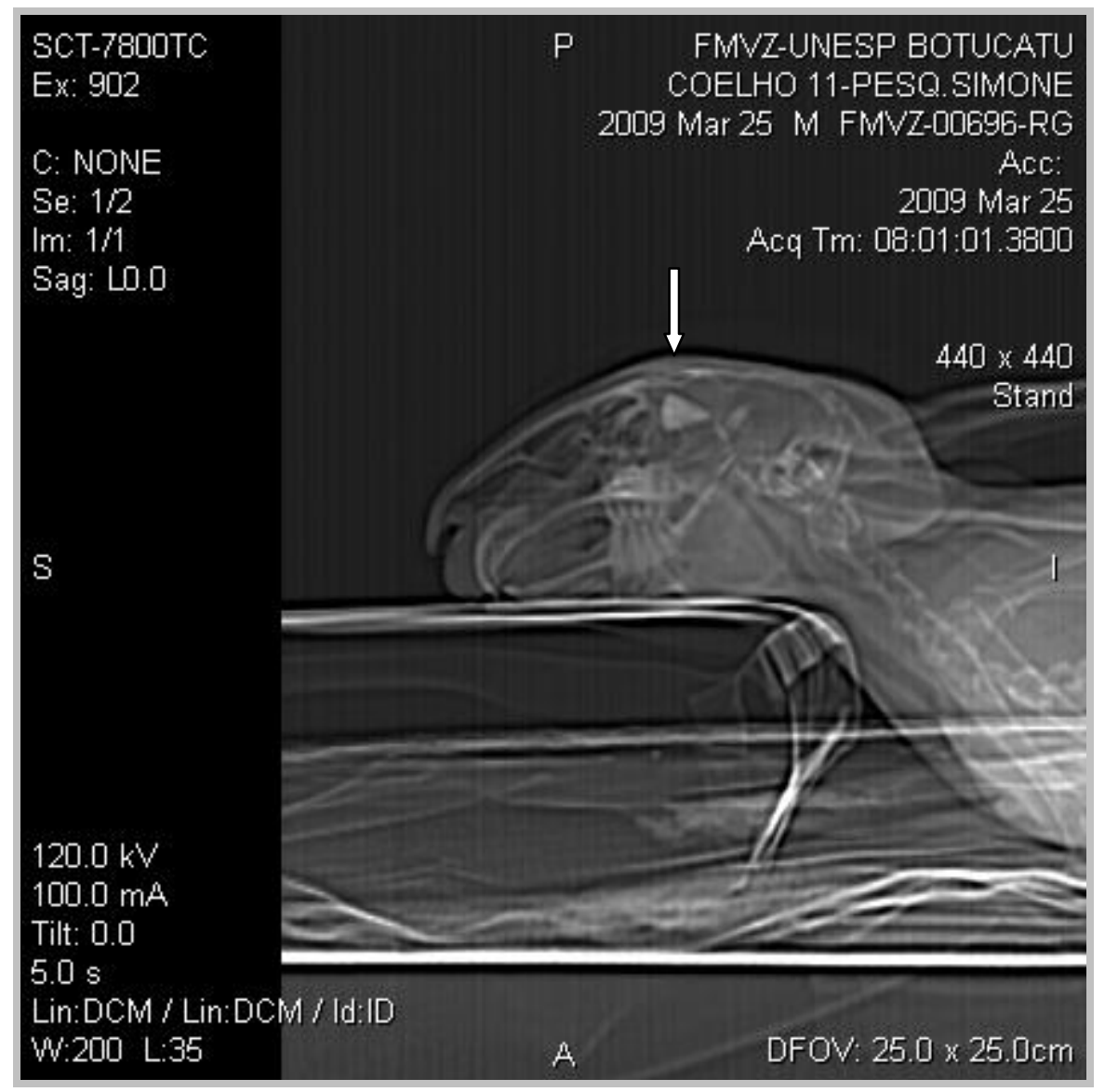

Figura 20. Tomografia computadorizada realizada nos coelhos em posição ventral com o crânio apoiado e elevado. Os cortes foram feitos de $1 \mathrm{x} 1 \mathrm{~mm}(1 \mathrm{~mm}$ de espessura por $1 \mathrm{~mm}$ de intervalo de reconstrução) e as imagens avaliadas em janela óssea e de partes moles, com o FOV ( Field Of View- Campo de Visão) de $11 \mathrm{~cm}$. Observar imagem do cone na cavidade orbitária (seta).

\subsubsection{Observações Tomográficas feitas no Grupo A}

Cortes tomográficos transversais da cavidade orbitária dos coelhos mostraram que a simetria da órbita operada com a contralateral foi mantida em todos os animais, não havendo alterações de estrutura óssea ou de partes moles. Nenhum animal desenvolveu extrusão do cone implantado. Em alguns coelhos, o posicionamento dos cones não foi mantido com o ápice na posição posterior, porém em todos, os cones permaneceram dentro da cavidade orbitária, na posição central, sendo possível observar as paredes ósseas da órbita e os músculos extra-oculares na posição anatômica. Coleções, edema, sinais infecciosos ou outras alterações não foram detectadas (Figura 21). 


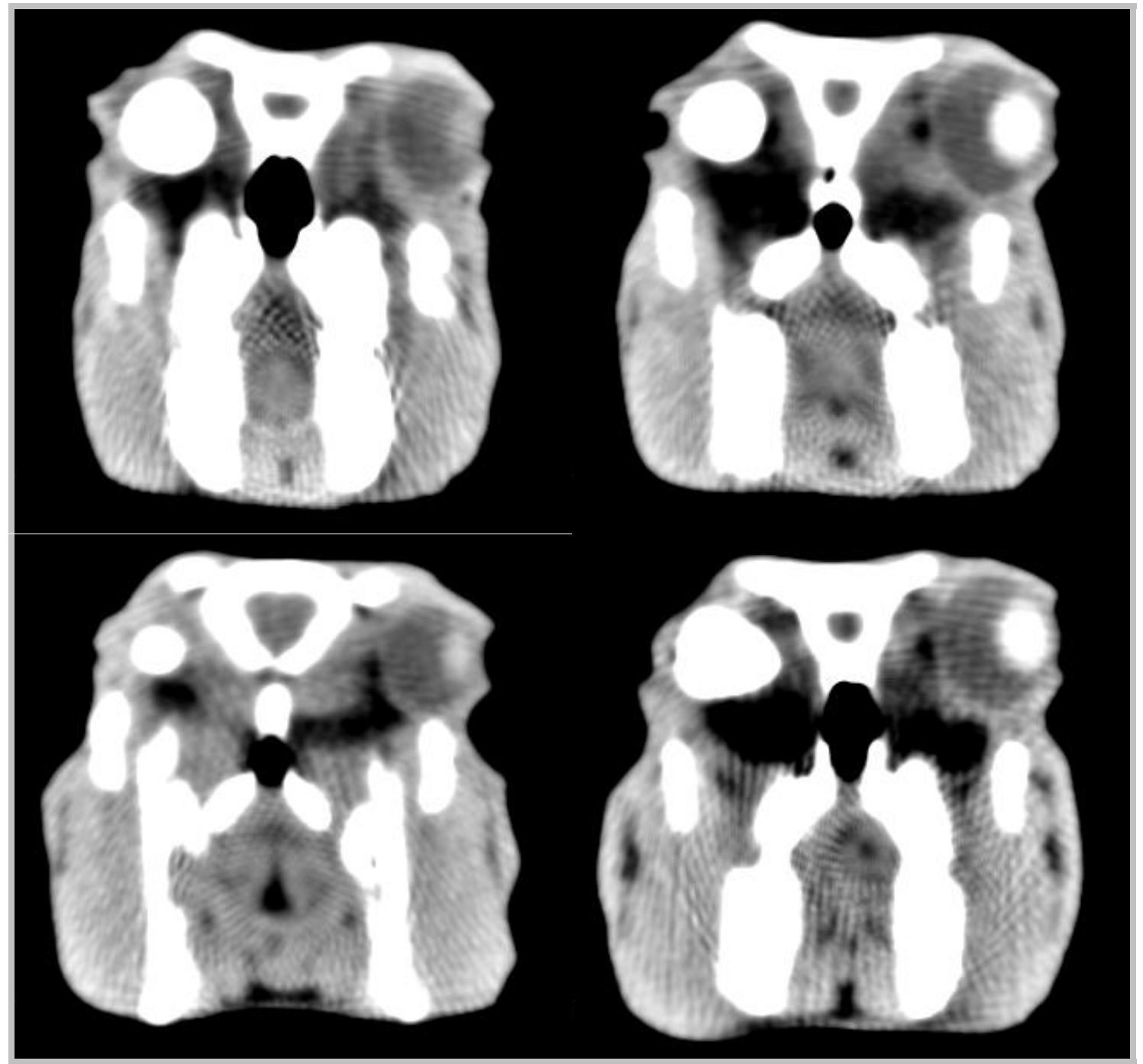

Figura 21. Cortes tomográficos do crânio do coelho na posição transversal, onde se observa na órbita direita, o cone de biovidro e, na esquerda, o bulbo ocular.

\subsubsection{Observações Tomográficas feitas no Grupo B}

Cortes tomográficos transversais da cavidade orbitária dos coelhos mostraram-se idênticos aos observados nos animais do Grupo A, com simetria das órbitas e sem alterações de estrutura óssea ou de partes moles. Nenhum animal desenvolveu extrusão do cone implantado e também neste grupo o posicionamento dos cones não foi mantido com o ápice na posição posterior, embora tenham permanecido na posição central. Coleções, edema, sinais infecciosos ou outras alterações não foram detectadas (Figura 22). 


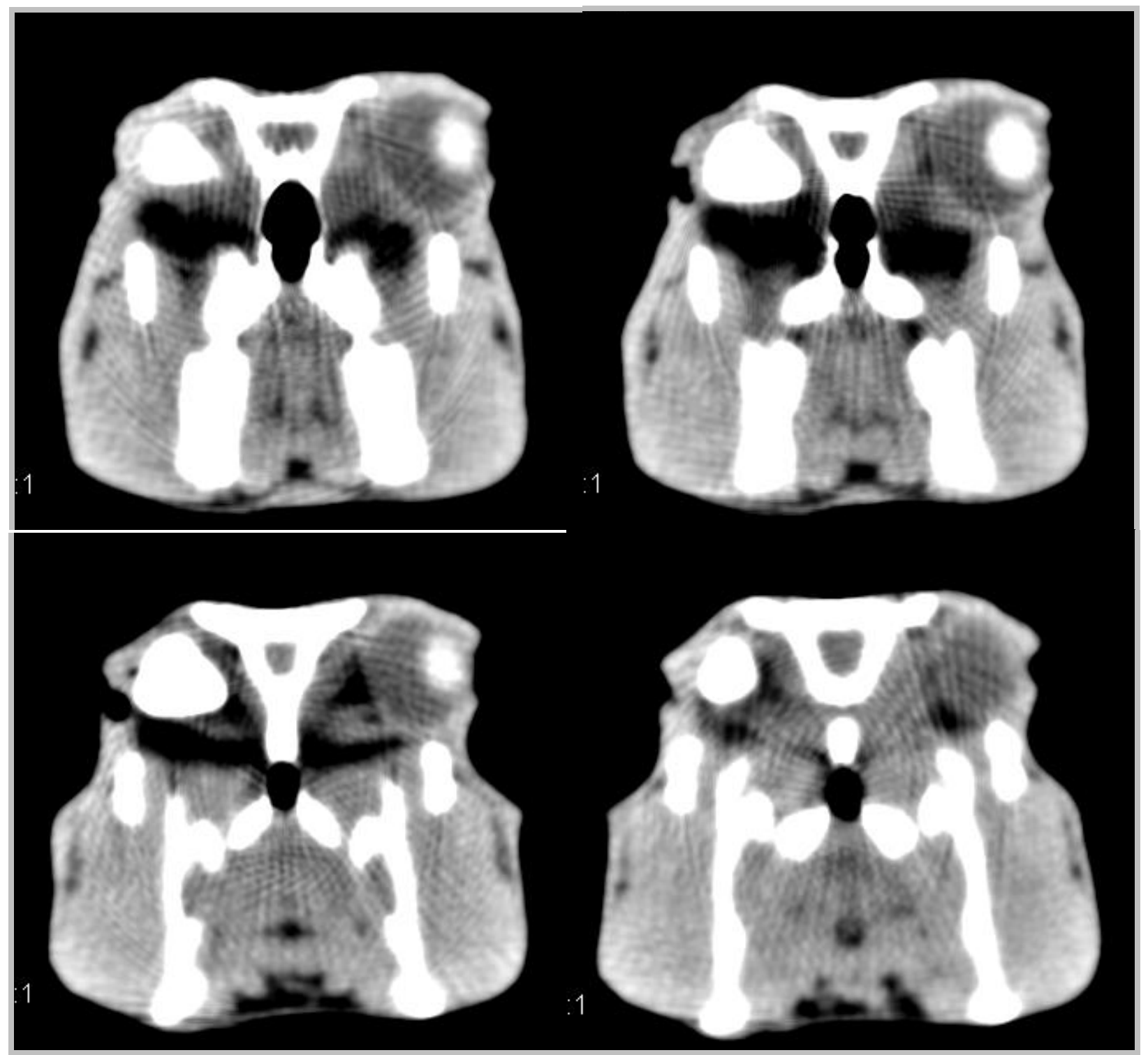

Figura 22. Cortes tomográficos do crânio do coelho na posição transversal, onde se observa na órbita direita, o cone de biovitrocerâmico I e, na esquerda, o bulbo ocular.

\subsubsection{Observações Tomográficas feitas no Grupo C}

Cortes tomográficos transversais da cavidade orbitária dos coelhos mostraram-se idênticos aos observados nos animais dos Grupo A e B, com todas as características dos grupos anteriores mantidas nestes animais (Figura 23). 


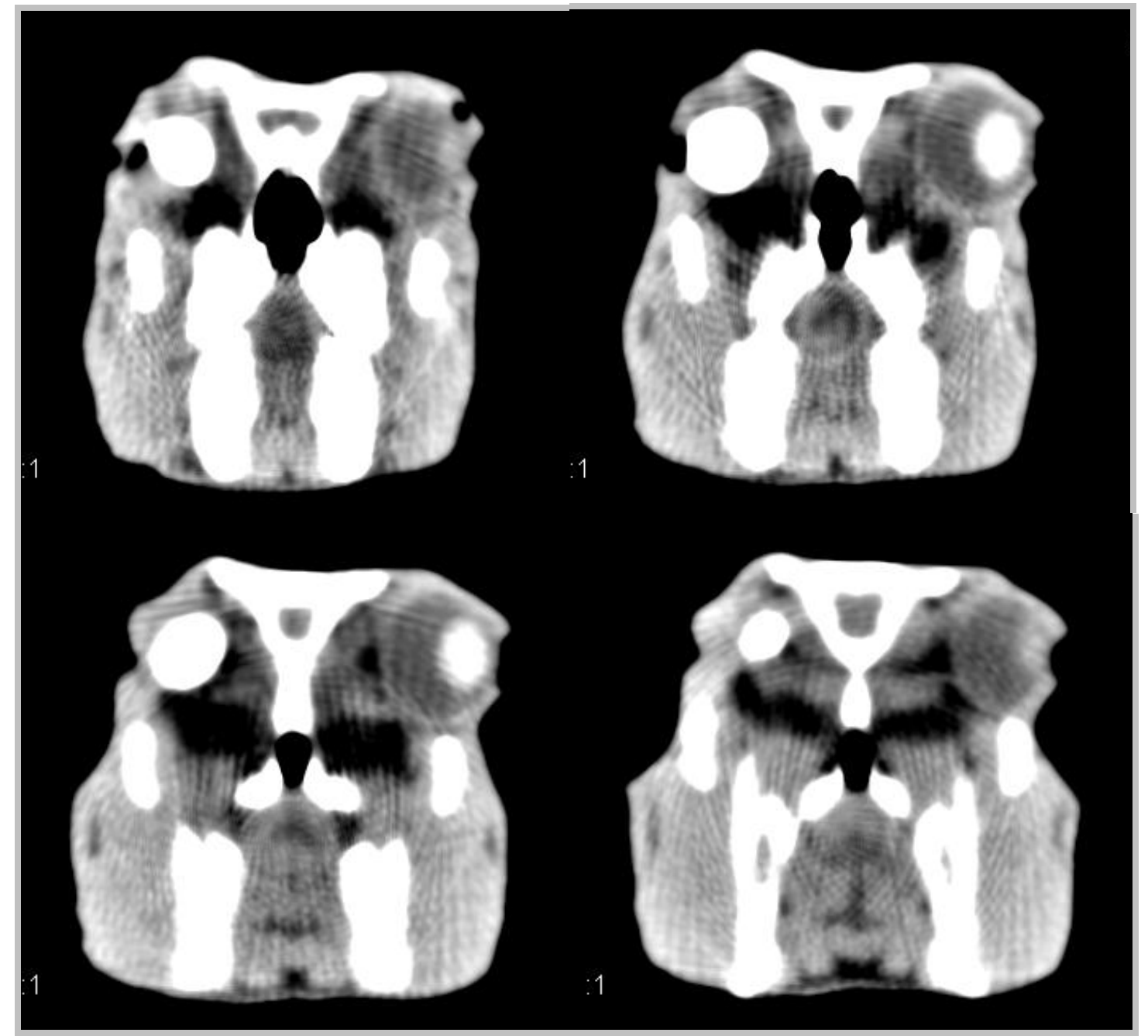

Figura 23. Cortes tomográficos do crânio do coelho na posição transversal, onde se observa na órbita direita, o cone de biovitrocerâmico II e, na esquerda, o bulbo ocular.

\subsection{Avaliação dos cones ao Microscópio Eletrônico de Varredura}

O exame ultra-estrutural foi realizado em animais do M3, avaliando-se a superfície dos cones.

Foi possível observar que a superfície dos diferentes biomateriais apresentava-se distinta na parte mais externa, local de contato com os tecidos do hospedeiro. 


\subsubsection{Observações Ultra-estruturais com Microscopia Eletrônica de}

\section{Varredura, feitas no Grupo A}

Nos materiais preparados para exame de ultra-estrutural da superfície dos cones, há nítida linha de fratura, separando uma estreita camada superficial de outra mais profunda. A linha de fratura tem estrutura regular, retilínea, de espessura homogênea, deixando espaço constante entre as duas camadas. Sobre o biomaterial há "rachaduras” de formato irregular, de aspecto semelhante a figuras geométricas. Na porção superficial destas duas camadas que se formaram, é possível observar maior rugosidade A quantidade de fibrose e células inflamatórias sobre o material é pequena, sendo possível observar o biovidro não revestido em várias localizações (Figura 24). No efeito de corte induzido para o preparo do material, o biovidro forma pequenas placas que se desprendem, expondo na porção mais profunda uma superfície muito lisa, brilhante e mais escura (figura 25). 


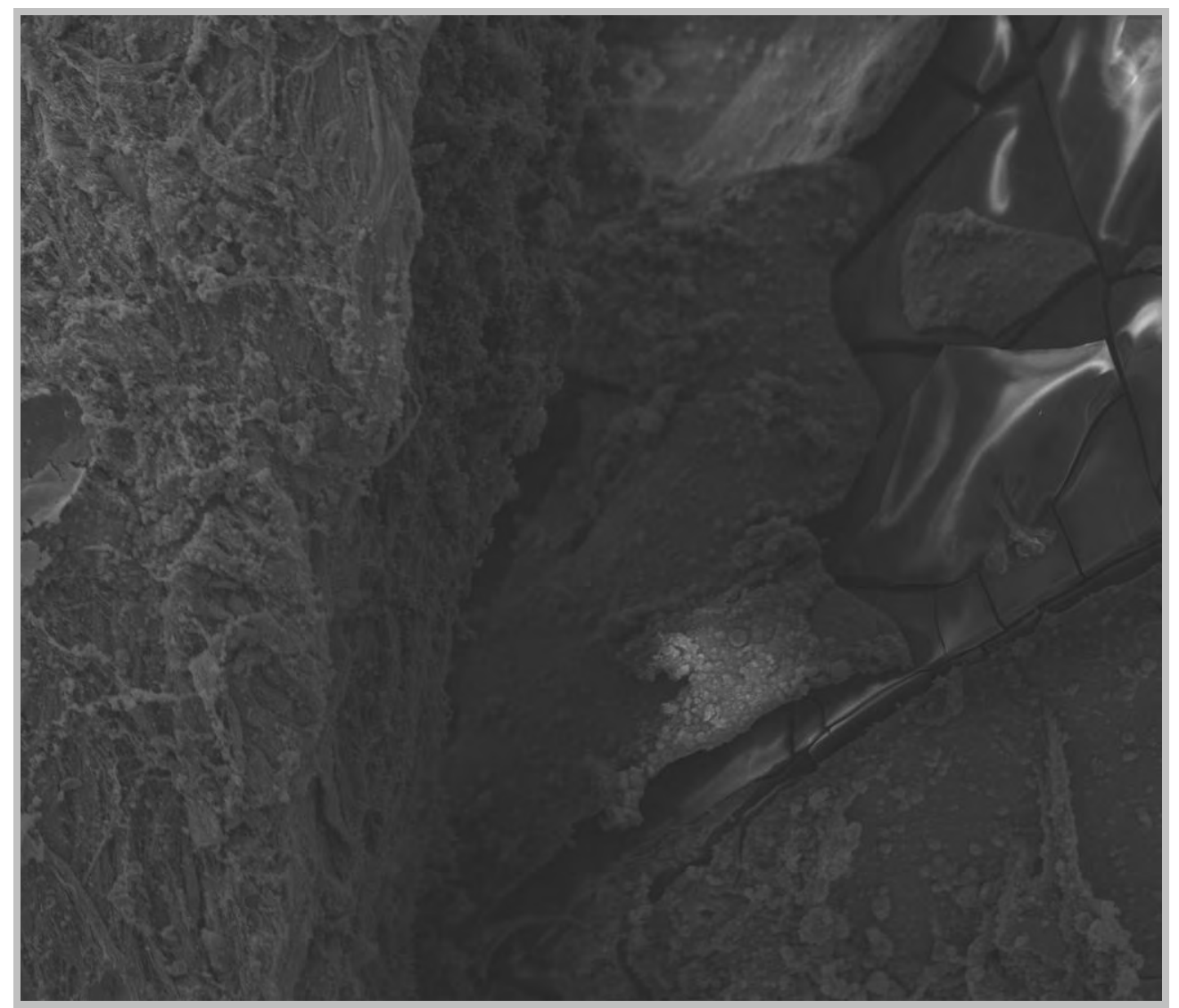

Figura 24. Imagem referente a animal do grupo A em M3. Fratura da camada mais externa do cone, separando uma camada mais densa do biomaterial. Na região mais interna o biovidro apresenta microfraturas (MEV 450X). 


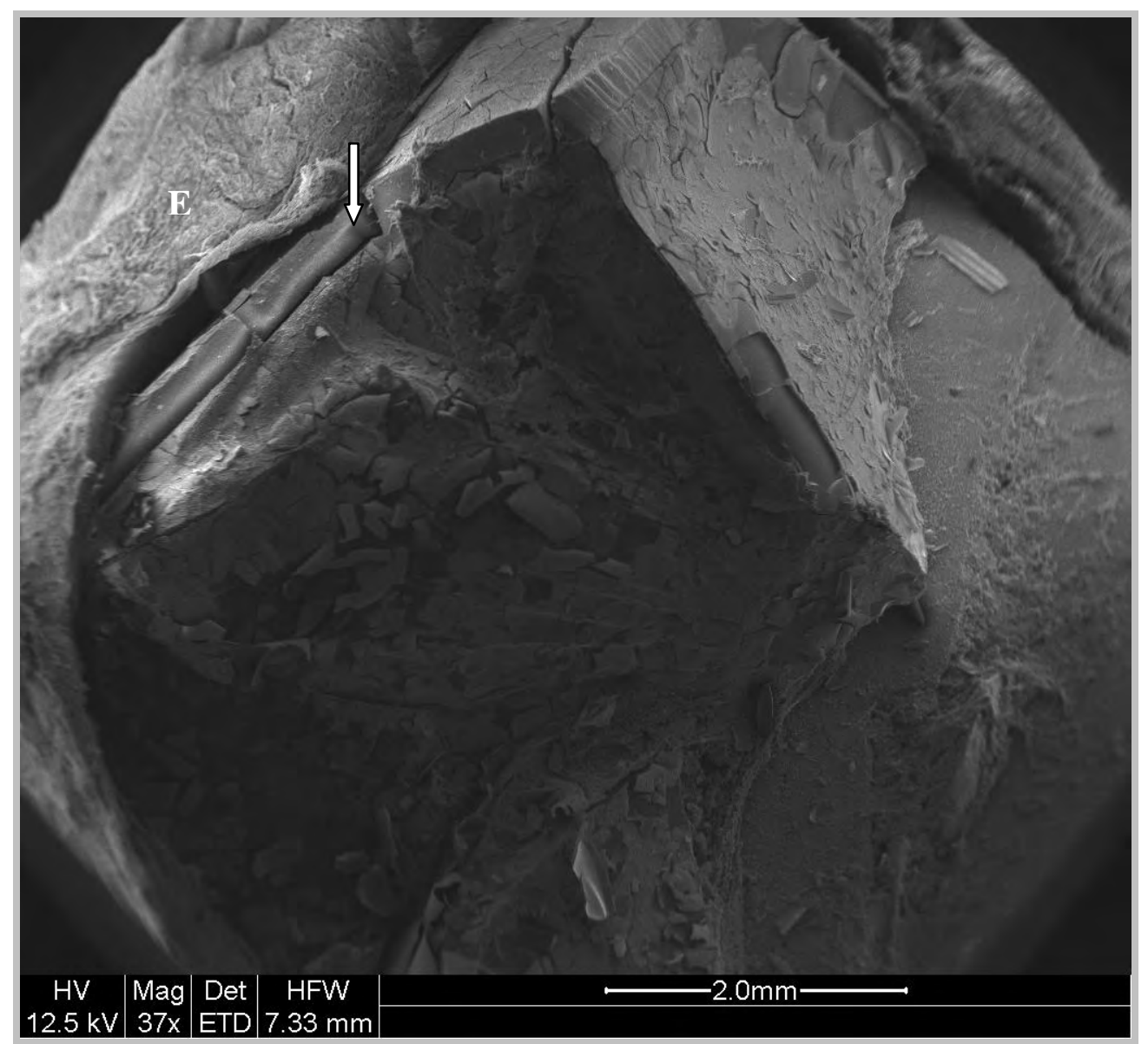

Figura 25. Imagem referente a animal do grupo A em M3. Fratura retilínea na superfície de contato do biovidro da esclera (seta). Efeito de corte induzido para o preparo do material, o biovidro forma pequenas placas que se desprendem. Esclera (E)(MEV 37X).

\subsubsection{Observações Ultra-estruturais com Microscopia Eletrônica de}

\section{Varredura, feitas no Grupo B}

Observa-se uma linha de fratura na camada superficial do material, irregular em forma e espessura, que separa o biomaterial em duas camadas distintas (figura 26). A linha é paralela a superfície, com porções retilíneas e segmentos angulares. Na porção superficial destas duas camadas que se formaram, é possível observar maior rugosidade. Em detalhe, a rugosidade, corresponde à fibrose formando uma verdadeira capa que reveste o material, entremeada por poucas hemácias e células inflamatórias. Na camada mais profunda, a superfície dos cones mostra-se mais lisa, com menor quantidade de células e com inúmeras 
"rachaduras" de formato de figuras geométricas, sem que exista separação da camada subjacente (figura 27). No efeito de corte induzido para o preparo do material, a superfície é lisa.

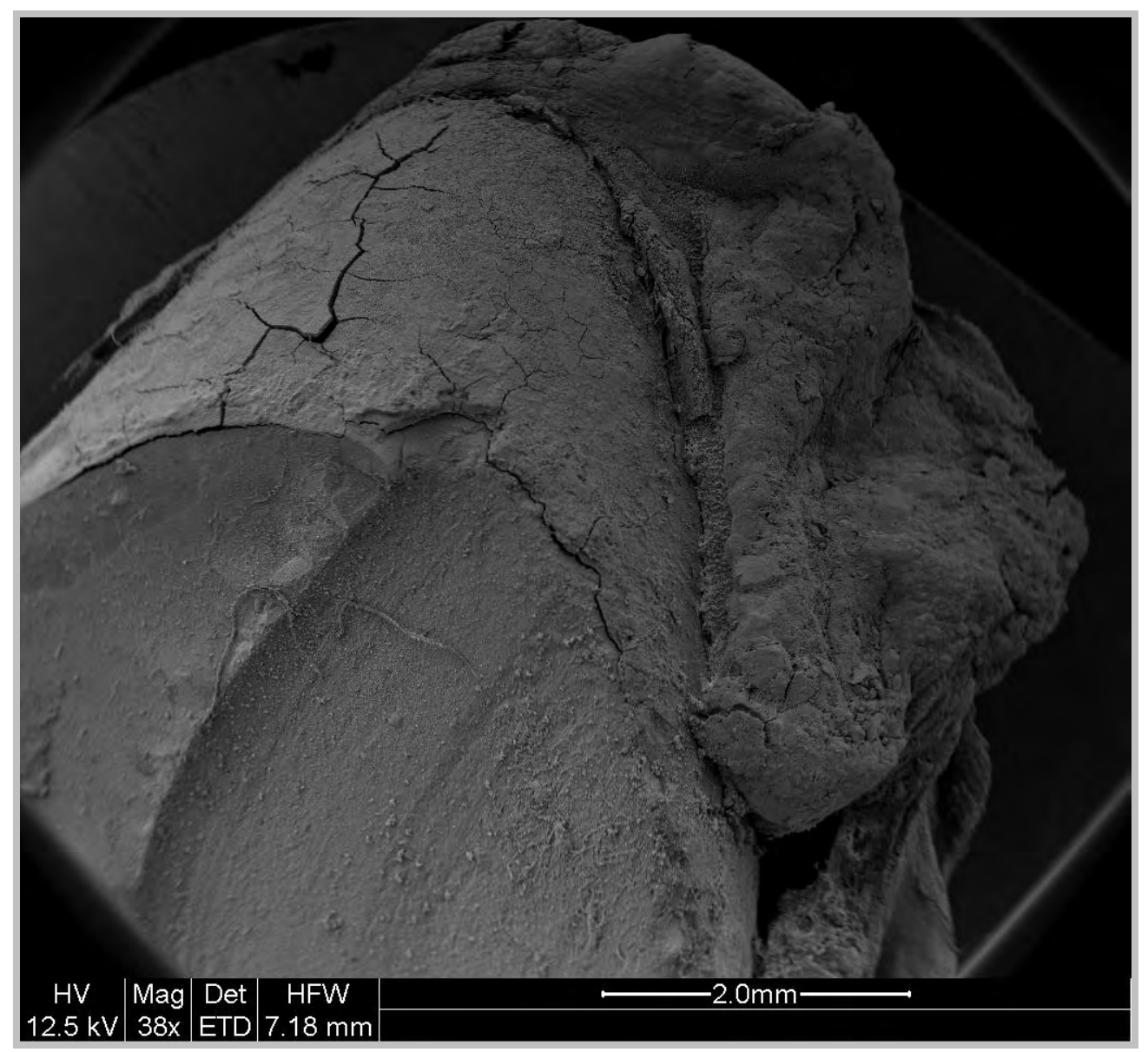

Figura 26. Imagem referente a animal do grupo B em M3. Presença da linha de fratura na camada superficial do material, separando o biomaterial em duas camadas distintas (MEV 38X). 


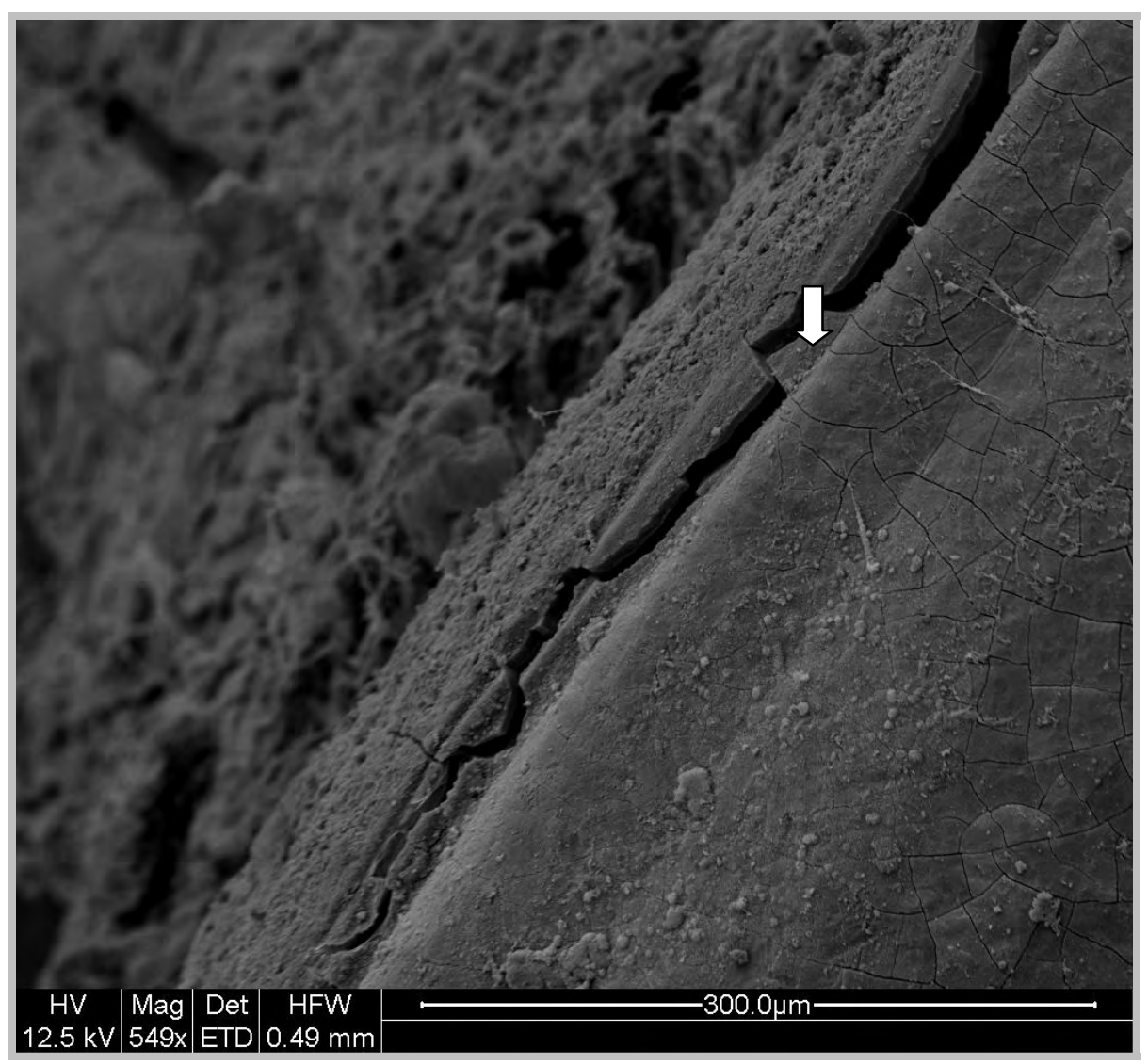

Figura 27. Imagem referente a animal do grupo B em M3. Presença das camadas superficial e profunda, com inúmeras "rachaduras" de formato de figuras geométricas (seta) (MEV 549X).

\subsubsection{Observações Ultra-estruturais com Microscopia Eletrônica de}

\section{Varredura, feitas no GrupoC}

A camada superficial é separada da profunda por linha de fratura semelhante a do Grupo B, ou seja, possui forma irregular, distância entre as duas partes que não é homogênea e não retilínea, com segmentos angulares. A superfície entre o biomaterial e o hospedeiro possui grande quantidade de fibrose que não permite a observação do biomaterial, com poucas células inflamatórias e poucas hemácias (figura 28). Em maior aumento, a capa de fibrose é vista como uma superfície algodonosa que envolve todo o cone (figura 29). No efeito de corte induzido para o preparo do material, a superfície é lisa. 


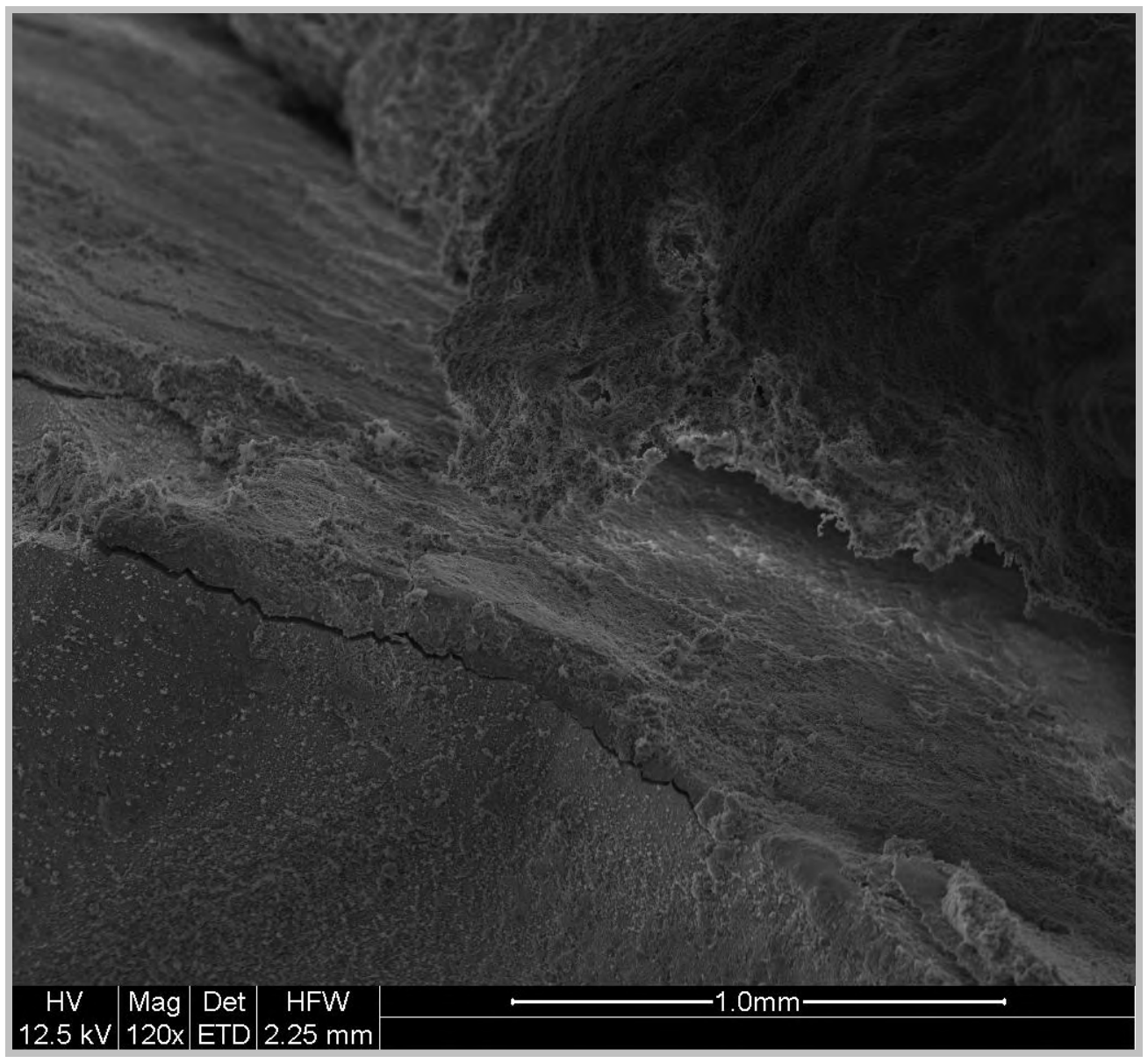

Figura 28. Imagem referente a animal do grupo C em M3. Superfície entre o biomaterial e o hospedeiro com grande quantidade de fibrose, não permitindo a observação do biomaterial, com poucas células inflamatórias e poucas hemácias (MEV 120X). 


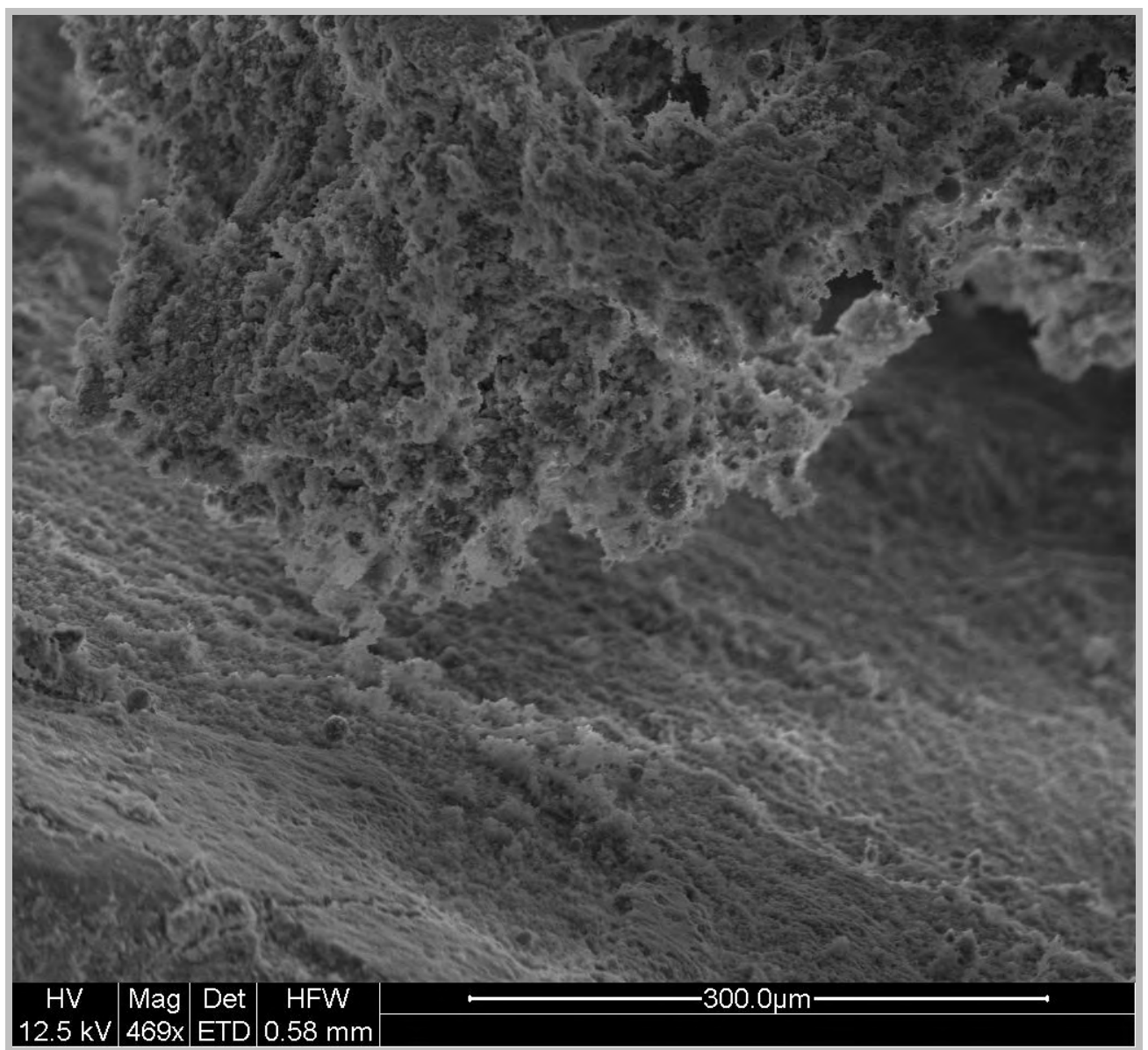

Figura 29. Imagem referente a animal do grupo $\mathrm{C}$ em M3. Presença de capa de fibrose é vista como uma superfície algodonosa que envolve todo o cone e não permite visibilizá-lo (MEV 469X). 


\section{DISCUSSÃO}

\section{Escolha do tema e modelo experimental}

Este estudo foi desenvolvido com a intenção de avaliar a biocompatibilidade do biovidro, do biovitrocerâmico I e do biovitrocerâmico II em cavidades evisceradas de coelhos, com o intuito de decidir se estes materiais, produzidos no Laboratório fornecedor, podem ser utilizados na reparação das cavidades enucleadas ou evisceradas, e qual dentre eles seria a melhor opção.

Para isso, foi utilizado um modelo experimental já estabelecido, empregado em outras pesquisas feitas nesta mesma Instituição, seguindo dentro da linha de pesquisa da orientadora do estudo.

A escolha pelo coelho foi feita, por ser este animal de fácil manipulação e manutenção, volume orbitário suficiente para a realização do procedimento de evisceração e colocação de uma inclusão, ser de baixo custo e de estar disponível em biotério especializado para criação e manutenção de nossa Instituição, além de se ter amplo domínio deste modelo experimental para este tipo de pesquisa. Também os procedimentos anestésicos, de administração de drogas e de manipulação para exames é mais simples quando se usa animais de pequeno porte.

A comparação entre três materiais diferentes foi adotada no sentido de se testar, em cavidade anoftálmica, os biomateriais fabricados a partir do vidro que já estão sendo testados em outras áreas da Medicina e Odontologia.

O procedimento dos três materiais foram realizados simultaneamente a fim de se avaliar a evolução temporal no tempo de estudo, excluindo-se variações climáticas e outras possíveis variáveis que pudessem influenciar nos resultados obtidos. 


\section{Quanto ao desenvolvimento dos cones para o estudo}

Apesar de o material usado para a fabricação dos cones já ser conhecido, a fabricação destes para o uso em cavidade anoftálmica não havia sido realizada. Para isso, dados relativos ao tamanho necessário dos cones foram obtidos de estudos prévios, alguns realizados nos nossos laboratórios, chegando-se a conclusão que seria possível usar uma inclusão de 10 a $12 \mathrm{~mm}$ em cavidades orbitárias de coelhos em fase de desmame (SEKUNDO; SEIFERT, 1998; SCHELLINI et al., 2003; FERRAZ et al., 2006; BRITO, 2008).

Como a intenção do presente estudo era estudar inclusões com formato de cones ao invés de esferas, foi necessário realizar estudos "piloto", partindo-se da dissecção do crânio do coelho, com avaliação do volume orbitário. A partir destas avaliações, chegou-se no formato e tamanho da prótese a ser fabricada: diâmetro anterior de $10 \mathrm{~mm}$, posterior de $3 \mathrm{~mm}$ e comprimento de $12 \mathrm{~mm}$.

Para a confecção do formato estabelecido, foi optado usar um molde de grafite de alta precisão. Inicialmente este molde tinha o formato do cone posterior e a parte anterior aberta. Porém, com os primeiros cones confeccionados, devido à tensão de superfície do vidro, observou-se que a parte anterior terminava com formatos diferentes (figura 30). Assim, optou-se por realizar um molde usando vácuo anterior (figura 31) para que todos tivessem a mesma forma final, sendo a parte externa formada pelo vácuo, retirada e polida (figura 32), mantenho a simetria de forma, de tamanho e peso em todas as próteses produzidas, mesmo utilizando-se materiais diferentes no processamento, como o biovidro ou o biovitrocerâmico (figura 33). 


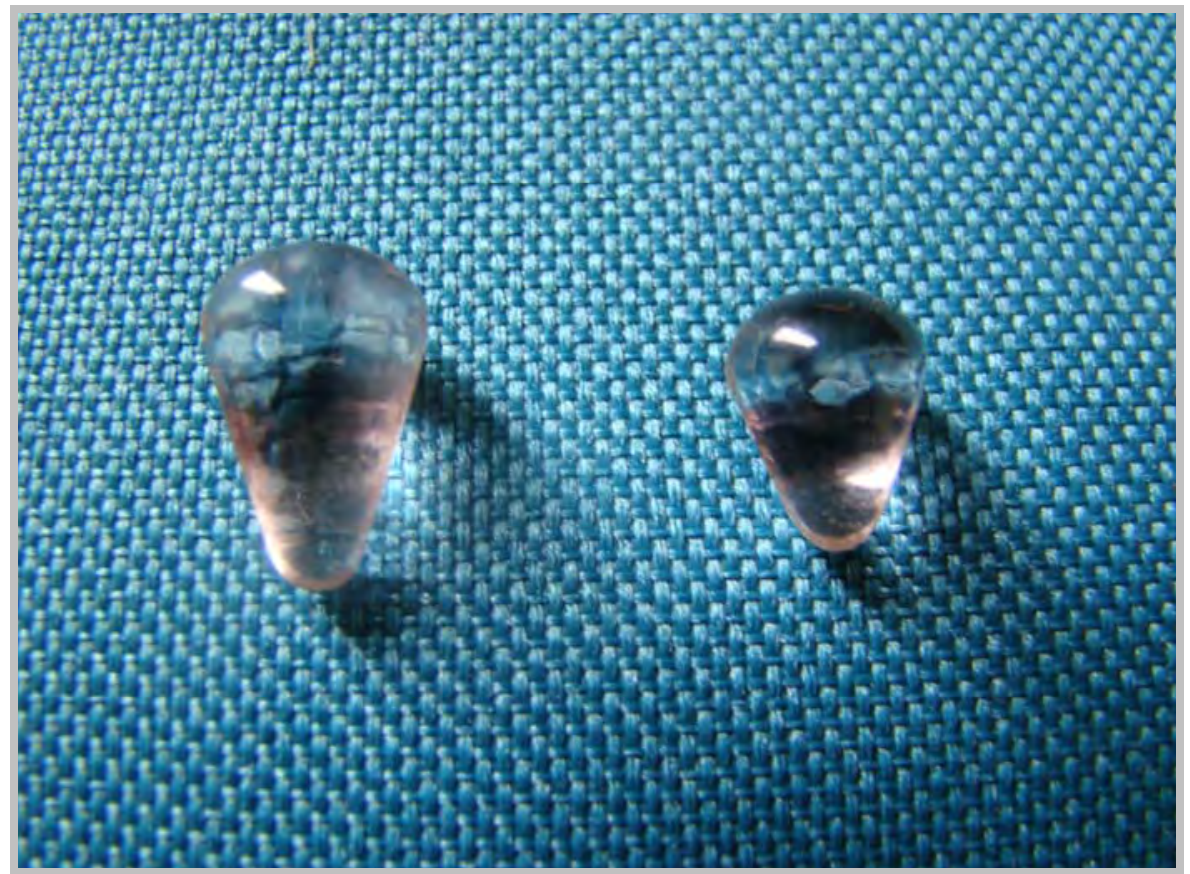

Figura 30. Primeiras próteses de vidro com formatos anteriores diferentes devido à tensão de superfície.

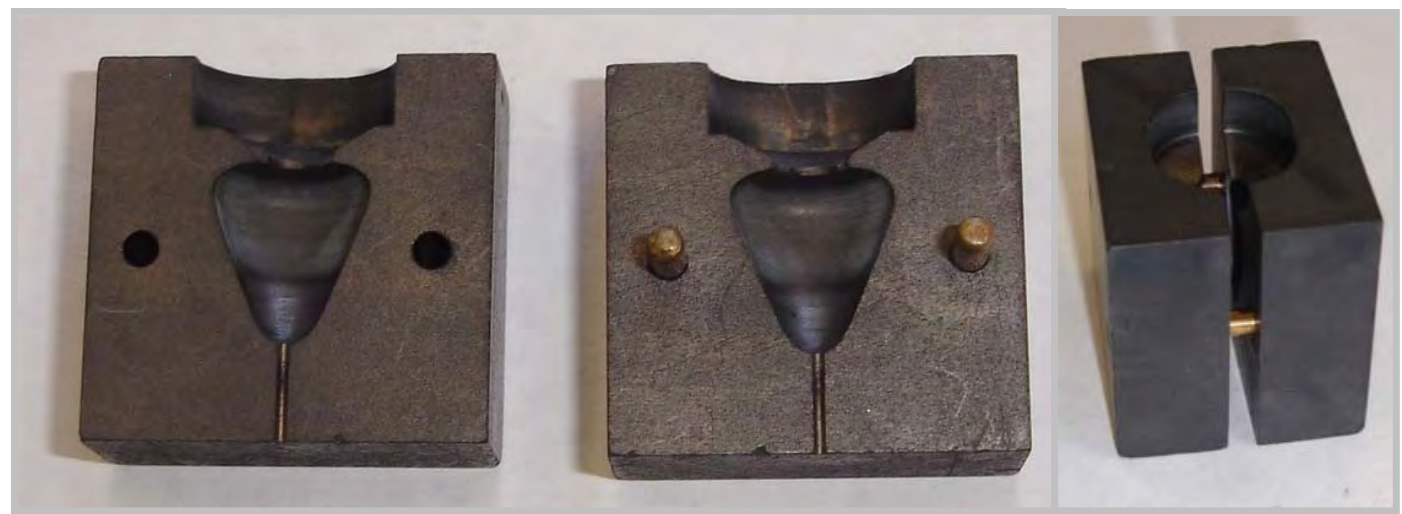

Figura 31. Molde de grafite de alta precisão, considerados a melhor opção para a obtenção de cones de mesmo padrão de formato e tamanho. 


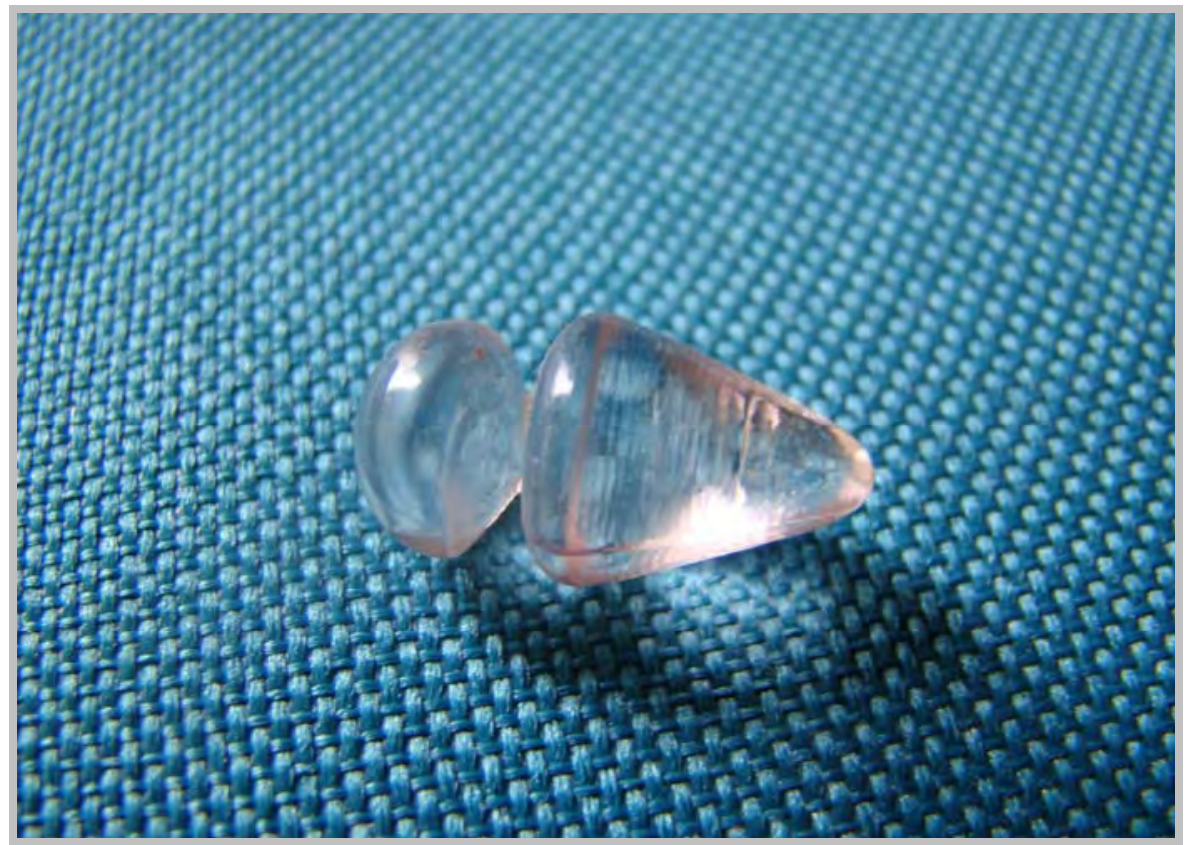

Figura 32. Formato da prótese de biovidro antes e após a aplicação do vácuo em sua confecção.

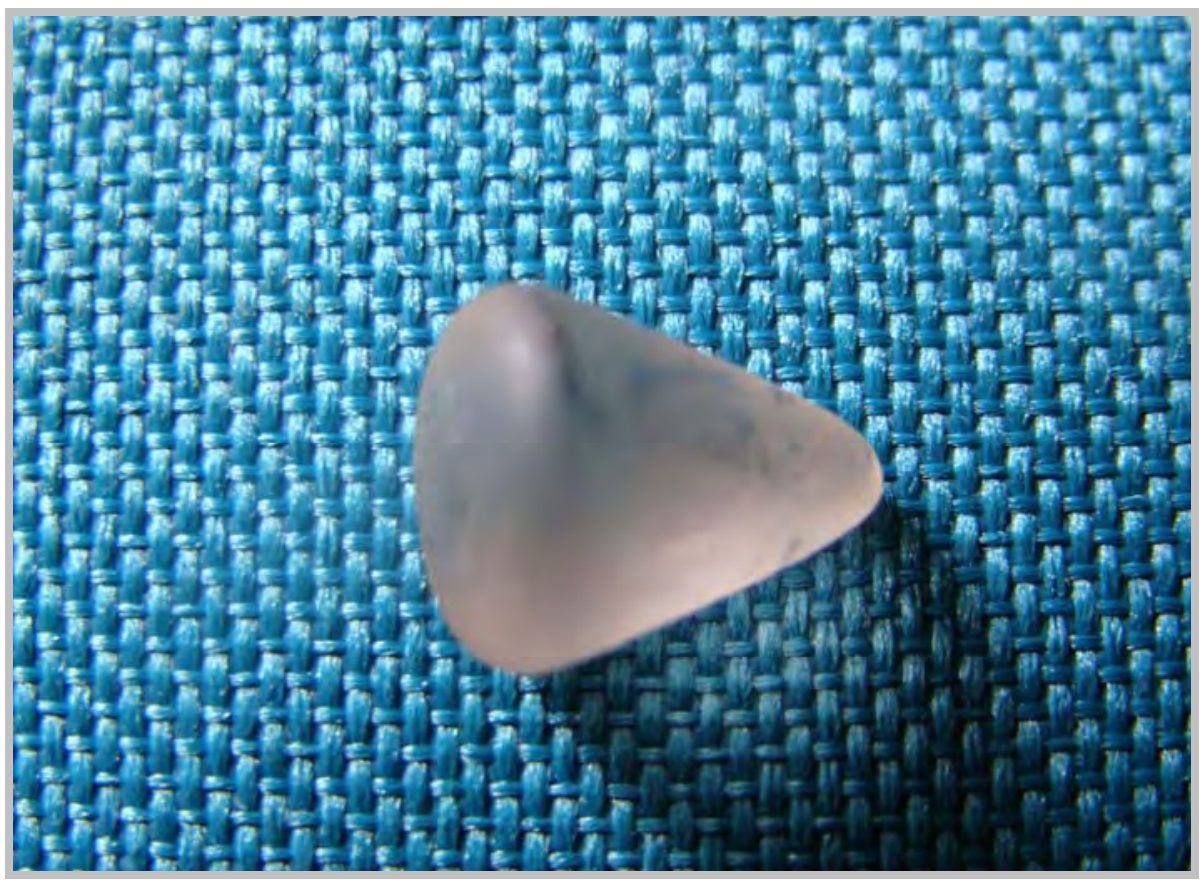

Figura 33. Prótese cônica de biovidro após o desbaste/lixamento. 
Na própria confecção das próteses, há formação de substâncias químicas que são capazes de apresentar interação com os tecidos do hospedeiro. Desta forma, optouse por testar estes cones de biovidro, biovitrocerâmico I e biovitrocerâmico II, partindo de estudos anteriores sobre integração dos materiais com o hospedeiro (IORDANIDOU; DE POTTER, 2004), na tentativa de se obter menor resposta inflamatória e menor chance de extrusão das próteses.

Assim, delineou-se este estudo, comparativo entre três diferentes tipos de biomateriais. Entretanto, é importante ainda se conhecer características específicas destes biomateriais.

Após os estudos “piloto”, conseguiu-se a confecção estável das próteses em forma de cone para o estudo em questão. Porém, após a produção do biovidro e dos biovitrocerâmicos I e II, não deve haver o contato dos biomateriais com o ar e nem com a água, necessitando eles permanecer em vácuo ou conservados em banho de acetona até que sejam esterilizados.

A esterilização deve ser feita em óxido de etileno, devendo ser feita a utilização cirúrgica em curto período de tempo, devido ao risco de mudança da estrutura do três biomateriais com o passar do tempo.

Ou seja, é necessário conhecer as características físico-químicas dos biomateriais que estarão sendo empregados, a fim de que se trabalhe dentro do que se considera como padrão dentro do assunto.

\section{Avaliação clínica dos animais e a análise da biocompatibilidade}

Para a análise da biocompatibilidade dos materiais utilizados, procedeu-se a avaliações clínicas diárias quanto à saúde geral e alterações locais da área cirúrgica, 
exame do peso dos animais e avaliações bioquímicas no início e final do experimento, exame de tomografia computadorizada no período de 45 dias após o início do experimento e avaliações morfológicas, realizadas ao final do período experimental.

A evolução clínica e do peso dos animais demonstrou que não houve interferência dos procedimentos realizados com a homeostase, havendo ganho de peso ao longo do tempo, o que já demonstra um curso normal de crescimento dos animais.

\section{Os exames bioquímicos}

Os exames bioquímicos foram realizados para a análise de toxicidade, ou seja, com o intuito de conhecer se o material de que foram confeccionados os cones poderia ser absorvido sistemicamente e acarretar repercussões para a saúde geral dos animais. Para isso foram avaliadas a função hepática (TGO, TGP, LDH, FA), cardíaca (CPK) e renal (Uréia, Creatinina).

Tendo em vista que no laboratório veterinário utilizado para esta pesquisa não há parâmetros de referência de normalidade para os exames realizados em coelhos como existe para humanos, foram colhidos exames antes da colocação dos cones, considerado o momento zero ou o padrão de normalidade para o estudo bioquímico, comparando-se com o obtido no momento do sacrifício, conforme já descrito por outros (BRITO, 2008; TURNER et al., 2009). (TURNER et al., 2009). Ou seja, com os valores obtidos no M0 foram feitas as outras comparações. Além disso, a maioria dos exames bioquímicos colhidos foi coincidente com os empregados por outros pesquisadores (YAMADA et al., 2004), o que permitiu que fossem feitas comparações entre estudos, tendo sido observados resultados semelhantes. 
Assim, com a análise dos exames laboratoriais, tentou-se detectar se a colocação dos cones poderia produzir alguma alteração no organismo, através de exames que refletem o funcionamento dos órgãos vitais (coração, fígado e rim). Alterações que poderiam ser encontradas nas dosagens pesquisadas poderiam inferir que o biomaterial pudesse ter sofrido absorção, atingido a circulação e assim, produzir efeitos deletérios ao organismo, devido a possíveis componentes tóxicos, mesmo à distância.

A avaliação dos parâmetros bioquímicos estudados mostrou que algumas variações existiram. Entretanto, no geral, as variações foram discretas e, embora com algumas diferenças estatísticas constadas, não houve motivo para acreditar que as variações não fossem apenas fisiológicas, sem significado clínico, mesmo porque muitas vezes os valores finais foram inferiores aos iniciais.

Desta forma, tais indicadores permitiram considerar que a presença dos cones de biovidro e biovitrocerâmico I e II não foram prejudiciais ao rim, fígado e coração, sendo possível considerar que os mesmos não interferiram na saúde geral dos animais.

\section{Avaliação da resposta cicatricial ao redor dos cones}

Todo material estranho que é implantado em um organismo vivo gera uma reação inflamatória que no presente estudo revelou-se desde o início (sete dias) com a formação de uma pseudocápsula ao redor dos cones, composta inicialmente por fibrina, que dará origem aos fibroblastos, além de células inflamatórias, hemácias e neovasos, denotando o processo de reparação tecidual. Esta pseudocápsula formada era composta por tecido conjuntivo frouxo no início e que foi se tornando mais denso, o que foi 
comprovado pelo exame morfométrico. A pseudocápsula é um tecido conjuntivo formado ao redor de qualquer corpo estranho ou processo inflamatório que se forme no sítio de lesão, dessa forma tentando deter a inflamação que ocorre no local.

Os animais do M1 apresentavam ainda bastante edema dos tecidos, presença de fibrina e de muitas hemácias, demonstrando resposta recente ao ato cirúrgico.

As células inflamatórias se modificam no sítio de reparação com o passar do tempo, passando de resposta inflamatória aguda para crônica. No início é comum o encontro dos neutrófilos, às vezes em grande quantidade, células características da resposta inflamatória aguda e neovasos. Com o passar do tempo, as características da resposta inflamatória passam para a fase crônica, observando-se os fibroblastos com sinais de células maduras. Estas mudanças caracterizam um processo de cicatrização (COTRAN et al., 1994) , com substituição do tecido lesado, por tecido conjuntivo.

A resposta inflamatória no sítio de implantação dos cones diminuiu gradativamente ao longo do período experimental. Esta mesma observação foi feita usando-se outros materiais (ANDERSON et al., 2002; FERRAZ et al., 2006; BRITO, 2008), podendo ser esta uma característica que indica ser o biomaterial compatível.

Em casos de implante uma placa de proteína morfogenética no assoalho da órbita de coelhos, foi verificada a existência de uma camada de tecido inflamatório envolvendo o implante após sete dias e, passados 30 dias, houve redução da espessura desse tecido, não havendo mais sinais de atividade inflamatória após 90 dias.(FERRAZ et al., 2007)

Alguns materiais suscitam o aparecimento de “células gigantes". Caso surgissem estas células, poderia haver a fagocitose de partes do material implantado, como já observado com esferas de hidroxiapatita sintética (RANZANI et al., 1997). 
Desta forma, outros fenômenos poderiam ser evidenciados, como a redução do volume do cone, por exemplo, que não foi detectado nem pelo exame de tomografia realizada aos 45 dias (animais dos três grupos pertencentes aos momentos M2 e M3) e nem na avaliação do cone ao ser extraído do organismo e destinado a avaliação histológica. Outro fenômeno possível seria que fragmentos do cone implantado poderiam ganhar a circulação, chegando até outros locais distantes, podendo ocorrer deposição em órgãos e sistemas, lesando-os. Devido a esta possibilidade, justificou-se o estudo dos exames bioquímicos, já comentados.

Um fator considerado positivo foi a não observância de alterações locais, não tendo ocorrido nenhuma extrusão dos cones implantados ou inflamação que fosse importante. Além disso, a resposta tecidual pode ser considerada semelhante a que ocorre quando se utilizam outros materiais em cavidades (RANZANI et al., 1997; FERRAZ et al., 2006; BRITO, 2008).

\section{Análise quantitativa da espessura da pseudocápsula e da} celularidade nos implantes de biovidro, biovitrocerâmico I e biovitrocerâmico II

A pseudocápsula, após a implantação de cones de biovidro, biovitrocerâmico I e biovitrocerâmico II, foi mais espessa no início do período experimental, nos três tipos de materiais utilizados. Isso porque logo após a implantação existem os fenômenos inflamatórios da fase aguda, com grande exsudação de líquidos e afluxo de células para o sítio cirúrgico (sete dias- M1). Com o passar do tempo, houve redução da espessura da pseudocápsula, sendo a espessura menor nos momentos M2 (90 dias) e M3 (180 dias), quando comparados ao momento M1 (sete dias). Os fenômenos que explicam esta 
redução podem ser: a redução do edema, das hemácias e a diminuição da quantidade de células inflamatórias (o que também foi constatado em exame quantitativo).

A comparação da espessura da pseudocápsula entre os biomateriais demonstrou que no grupo C ela era mais espessa aos sete e 180 dias, sinal de que o biovitrocerâmico II causou maior reação inflamatória durante todo o experimento.

Esta pseudocápsula, em cada momento do estudo, apresentava-se com diferença de espessura nos diferentes locais de medida, o que nos levou a estabelecer locais fixos para a avaliação (anterior, posterior, 3 e 9 horas). A avaliação estatística destas variações mostrou que a região denominada anterior, era a mais espessada em relação à posterior, 3h e 9h, nos M1 e M3, devido possivelmente a resposta inflamatória mais exacerbada, pois foi evidente que na região do sítio cirúrgico e local da sutura com o uso de fio não absorvível, havia maior processo inflamatório. Além disso, esta região fica mais exposta aos fatores ambientes que as demais, com maior risco de contaminação. Esta diferença havia sido observada ao exame macroscópico da lâmina de HE e foi confirmada pela avaliação morfométrica.

Os resultados encontrados na espessura da pseudocápsula são semelhantes aos encontrados por França (2005) ao estudar um compósito bioativo de matriz polimérica.

O exame morfométrico confirmou também a redução da espessura da pseudocápsula, com valores estatisticamente significativos, ao longo do experimento, fato considerado muito positivo, uma vez que os materiais testados mostraram não suscitar grandes reflexos em termos de inflamação tecidual tardia.

Neste mesmo sentido, a reação inflamatória aferida nas lâminas foi estatisticamente significativa no momento M1 (sete dias), sendo maior nos Grupos B e 
C (biovitrocerâmico I e II) em comparação com o Grupo A (biovidro). Esta diferença também foi observada no Grupo C em relação aos momentos do estudo, ou seja, com diminuição significativamente importante do M1 para o M2 e M3 (RANZANI et al., 1997; FERRAZ et al., 2006; BRITO, 2008).

\section{Análise do colágeno nos cones de biovidro, biovitrocerâmico I e biovitrocerâmico II}

A avaliação do colágeno não demonstrou diferença estatística entre os grupos nos três momentos do estudo. Mesmo tendo sido encontrado diferença estatística no Grupo B entre os momentos M1 e M2, estes valores não foram altos e nem muito diferentes aos observados nos Grupos A e C. Com estas observações pode-se verificar que os cones implantados não geraram resposta inflamatória exacerbada e assim não produziram cicatrização anormal dos tecidos cicatriciais, não formando fibrose importante no local de contato entre o cone e o tecido do hospedeiro, nem mesmo na região anterior, local do sítio cirúrgico.

\section{Avaliação da Tomografia Computadorizada}

Às imagens obtidas no exame de Tomografia Computadorizada dos coelhos observou-se bom posicionamento dos cones na órbita do coelho, sendo este exame um excelente método diagnóstico para avaliação do material implantado na cavidade anoftálmica. A desvantagem é a necessidade de anestesia do animal para a realização do exame, uma vez que este não pode se mover durante a realização do procedimento. Somente uma analgesia do animal foi tentada, mas impediu a realização da Tomografia 
por ser rápida a recuperação do coelho que acordava durante a tomada das imagens pelo aparelho.

Com o exame foi possível avaliar a ausência de coleções e processos infecciosos ao redor dos cones e observar a simetria existente entre o lado operado e o contra-lateral. Também pode ser observado que os cones não receberam vascularização em seu interior, o que seria de se esperar, já que os mesmos não possuem poros. Este procedimento foi muito empregado para observar o tempo de colonização das inclusões integráveis, tomado como parâmetro para a colocação dos pinos, o que não foi nosso objetivo no presente estudo.

O posicionamento do cone intraorbital não mantido com o ápice posterior e apresentando diferentes posições, observado no exame de Tomografia Computadorizada, pode ter sido causado durante o ato cirúrgico e não ser ter sido ocasionado pelo material ou resposta inflamatória, isso porquê, durante o procedimento cirúrgico, após a colocação do biomaterial na cavidade escleral, observou-se que quanto menor era esta cavidade, já durante a sutura esclero-escleral, o cone mudava de posição em que era inicialmente colocado. Como o processo de integração entre material e hospedeiro inicia-se sete horas após o contato com fluídos (PEITL et al., 2001), o material deve ter ficado na posição do final da cirurgia.

\section{Avaliação da Microscopia Eletrônica de Varredura}

Os fenômenos observados no exame ultra-estrutural podem ser explicados pelas alterações físico-químicas que ocorrem na superfície dos biomateriais quando possuem contato com o tecido vivo. 
Os cones, logo após entrarem em contato com os fluídos dos tecidos vivos, começam a sofrer alterações em sua composição físico-química, através da seqüência de cinco etapas de reações:

1) Lixiviação seletiva: Rápida troca iônica entre a solução, doadora de prótons $\mathrm{H}^{+}$, e a superfície do biovidro liberando sódio $(\mathrm{Na})$, potássio (K) e ou fósforo. Formando assim os grupos silanois, Si-OH, na superfície da inclusão..

2) Dissolução química: ruptura das ligações químicas -Si-O-Siformando na solução os grupos $\mathrm{Si}(\mathrm{OH})_{4}$. Na superfície atacada do biovidro permanece os grupos silanois .

3) Repolimerização ou condensação: formação da fase gel rica em $\mathrm{SiO}_{2}$, com a formação de "grandes poros” pela reincorporarão á superfície dos grupos $\mathrm{Si}(\mathrm{OH})_{4}$ presentes na solução.

4) Fosfato cálcio amorfo: migração do $\mathrm{Ca}^{2+}{\mathrm{e} \mathrm{PO}^{3-}}_{4}$, que aumenta gradativamente devido à corrosão dos íons e também aqueles lixiviados nas etapas anteriores. O acumulo destes íons sobre a camada rica em sílica, forma a CaO- $\mathrm{P}_{2} \mathrm{O}_{5}$ amorfa.

5) Cristalização: formação do hidroxi-carbonato apatita (HCA) via incorporação de grupos hidroxila e ânios $\mathrm{CO}^{2-}{ }_{3}$ da solução (PEITL et al., 2001).

Estes processos levam a formação de uma dupla camada (item 3 e 5), uma de gel e outra de apatita. Esta camada ao sofrer ressecamento pelo glutaraldeído para preparação do material para análise ao Microscópio de Varredura, destacou-se por trincamento, sendo visível a análise das peças. 
Além disso, devido à fase de repolimerização e conseqüente a formação de poros na superfície, foi possível identificar a integração do material com o hospedeiro (figura 34).

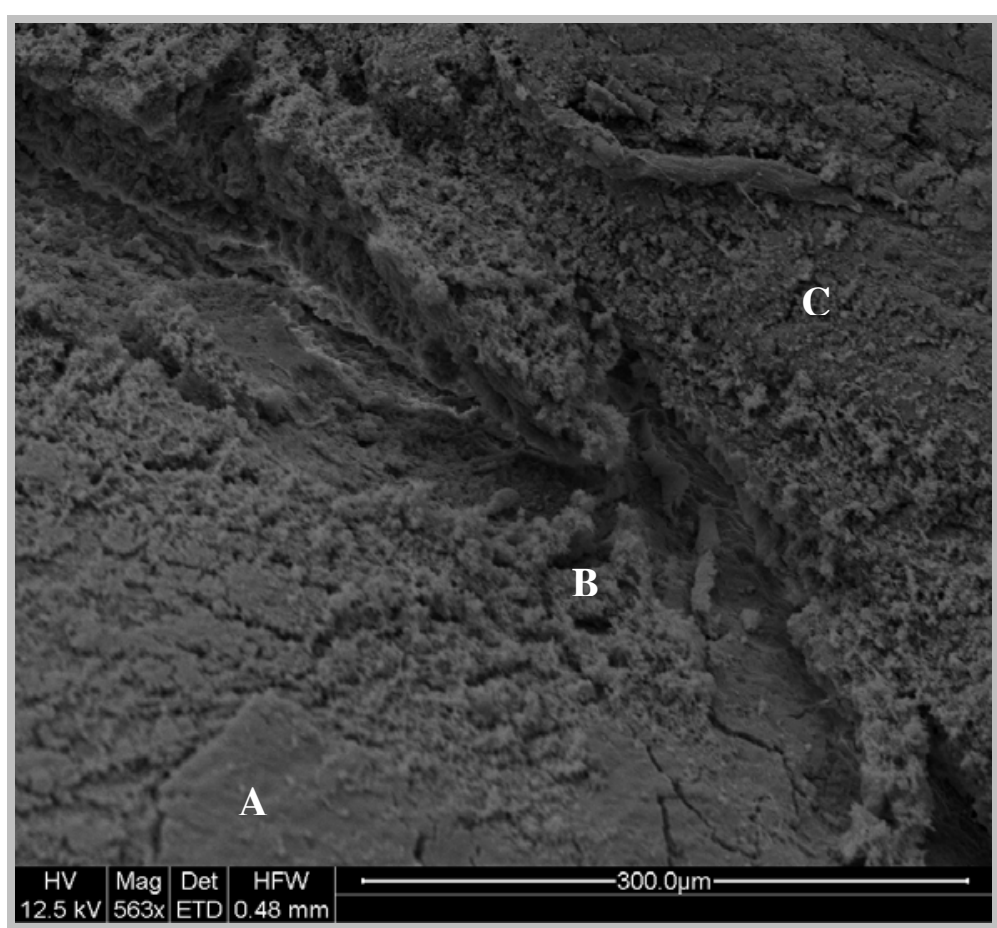

Figura 34. Imagem da Microscopia Eletrônica de Varredura. A) biomaterial. B) integração. C) material do hospedeiro.

A análise das imagens ultra-estruturais mostrou que na parte externa do cone em contato com o tecido do hospedeiro, houve a formação de uma capa de resposta inflamatória menor nos cones de biovidro em relação aos de biovtitrocerâmico I e II, observado pela possibilidade de se visualizar o material no grupo A e não no B e C e pela quantidade de células encontradas. Estes achados confirmam os observados na microscopia óptica e apontam para a superioridade do biovidro (Grupo A), em relação aos demais. 


\section{CONCLUSÃO}

Após as análises realizadas e frente às condições experimentais empregadas, pode-se concluir que:

- a colocação dos cones nas cavidades evisceradas mostrou que não houve interferência dos mesmos com parâmetros clínicos, permanecendo os animais com a saúde geral inalterada, assim como com ausência de sinais desfavoráveis no local de implantação;

- a análise morfológica apontou para a superioridade dos cones de biovidro, os quais apresentaram menor reação inflamatória e menor formação da pseudocápsula que os cones de biovitrocerâmico I e II;

- o exame tomográfico mostrou que os cones não migraram e que não houve formação de coleções ou processo inflamatório ao redor dos mesmos nos três grupos experimentais;

- a análise feita por Microscopia Eletrônica de Varredura confirmou que os cones de biovidro apresentaram menor reação inflamatória que os demais.

Sendo assim, pode-se concluir que os cones de biovidro e os de biovitrocerâmico I e II podem ser úteis para a reparação de cavidades anoftálmicas. Os cones de biovidro mostraram-se superiores aos de biovitrocerâmico, devido ao fato de provocarem menor reação inflamatória tecidual. 


\section{9 - REFERÊNCIAS BIBLIOGRÁFICAS*}

Amato MM, Blaydon SM, Scribbick FW, Jr., Belden CJ, Shore JW, Neuhaus RW et al. Use of bioglass for orbital volume augmentation in enophthalmos: a rabbit model (oryctolagus cuniculus). Ophthal Plast Reconstr Surg .2003; 19 (6): 455-65.

Anderson RL, Yen MT, Lucci LM, Caruso RT. The quasi-integrated porous polyethylene orbital implant. Ophthal Plast Reconstr Surg .2002; 18 (1): 50-5.

Beaver HA, Patrinely JR, Holds JB, Soper MP. Periocular autografts in socket reconstruction. Ophthalmology .1996; 103 (9): 1498-1502.

Blaydon SM, Shepler TR, Neuhaus RW, White WL, Shore JW. The porous polyethylene (Medpor) spherical orbital implant: a retrospective study of 136 cases. Ophthal Plast Reconstr Surg .2003; 19 (5): 364-71.

Brito MM. Análise da biocompatibilidade da esfera de quitosana porosa em cavidade eviscerada de coelho. Estudo comparativo com polietileno poroso. Dissertação de Mestrado, Faculdade de Medicina de Botucatu, Universidade Estadual Paulista, 2008. pp.94.

Chen QZ, Rezwan K, Armitage D, Nazhat SN, Boccaccini AR. The surface functionalization of 45S5 Bioglass-based glass-ceramic scaffolds and its impact on bioactivity. J Mater Sci Mater Med .2006; 17 (11): 979-87.

Cotran RS, Kumar V, Robbins SL, Shoen FJ. Robbins Pathologic Basis of Disease. In: Cotran RS, Kumar V, Robbins SL, Shoen FJ. Patologia estrutural e funcional. Philadelphia: W.B. Saunders Company, 1994. Cap. 3 , p. 45-83.

Custer PL , Trinkaus KM. Porous implant exposure: Incidence, management, and morbidity. Ophthal Plast Reconstr Surg .2007; 23 (1): 1-7.

Ferraz LC, Schellini SA, Wludarski SL, Padovani CR. [Gel and porous polyethylene implants in the rabbit anophthalmic cavity]. Arq Bras Oftalmol .2006; 69 (3): 305-8.

Ferraz LC, Schellini SA, Wludarski SL, Padovani CR, Muller S. [2-octyl-cyanoacrylate

*Comitê Internacional de Editores de Revistas Médicas. Requisitos uniformes para originais submetidos a revistas biomédicas. J Pedriatr 1997; 73: 213-24. National Library of Medicine. List of journals indexed in Index medicus. Washington, 2001. 248p 
in rabbit anophthalmic cavity reconstruction]. Arq Bras Oftalmol .2007; 70 (2): 221-4.

França VP. Estudo comparativo experimental de compósito bioativo de matriz polimérica para aplicação em cirurgia plástica ocular na substituição tecidual. Tese de doutoramento, Faculdade de Medicina, Universidade Federal de Minas Gerais, 2003. pp.265.

França VP, Figueiredo ARP, Vasconcelos AC, Oréfice RL. Estudo comparativo experimental de compósito bioativo de matriz polimérica para aplicação em cirurgia plástica ocular na substituição tecidial. Arq Bras Oftalmol .2005; 68 (4): 425-31.

Fratzl P , Barth FG. Biomaterial systems for mechanosensing and actuation. Nature .2009; 462 (7272): 442-8.

Goldberg RA, Dresner SC, Braslow RA, Kossovsky N, Legmann A. Animal model of porous polyethylene orbital implants. Ophthal Plast Reconstr Surg .1994; 10 (2): 104-9.

Gougelman HP. The evolution of the ocular mobility implant. Int Ophthalmol Clin .1976; 10 689-711.

Greenlee TK, Jr., Beckham CA, Crebo AR, Malmorg JC. Glass ceramic bone implants. J Mater Sci Mater Med .1972; 6 (3): 235-44.

Gupta BK, Edward D, Duffy MT. 2-Octyl cyanoacrylate tissue adhesive and muscle attachment to porous anophthalmic orbital implants. Ophthal Plast Reconstr Surg .2001; 17 (4): 264-9.

Habal MB. Aesthetic considerations in the reconstruction of the anophthalmic orbit. Aesthetic Plast Surg .1987; 11 (4): 229-39.

Hench LL. The story of Bioglass. J Mater Sci Mater Med .2006; 17 (11): 967-78.

Hsu WC, Green JP, Spilker MH, Rubin PA. Primary placement of a titanium motility post in a porous polyethylene orbital implant: animal model with quantitative assessment of fibrovascular ingrowth and vascular density. Ophthal Plast Reconstr Surg .2000; 16 (5): 370-9.

Iordanidou V , De Potter P. Porous polyethylene orbital implant in the pediatric population. Am J Ophthalmol .2004; 138 (3): 425-9. 
Jordan DR, Brownstein S, Gilberg S, Matthew B, Mawn L, Khouri L. Investigation of a bioresorbable orbital implant. Ophthal Plast Reconstr Surg .2002; 18 (5): 342-8.

Jordan DR, Hwang I, McEachren T, Brownstein S, Gilberg S, Grahovac S et al. Brazilian hydroxyapatite implant. Ophthal Plast Reconstr Surg .2000a; 16 (5): 363-9.

Jordan DR, Mawn LA, Brownstein S, McEachren TM, Gilberg SM, Hill V et al. The bioceramic orbital implant: a new generation of porous implants. Ophthal Plast Reconstr Surg .2000b; 16 (5): 347-55.

Karesh JW. Biomaterials in ophthalmic plastic and reconstructive surgery. Curr Opin Ophthalmol .1998; 9 (5): 66-74.

Klapper SR, Jordan DR, Ells A, Grahovac S. Hydroxyapatite orbital implant vascularization assessed by magnetic resonance imaging. Ophthal Plast Reconstr Surg .2003; 19 (1): 46-52.

Lin CJ, Liao SL, Jou JR, Kao SC, Hou PK, Chen MS. Complications of motility peg placement for porous hydroxyapatite orbital implants. Br J Ophthalmol .2002; 86 (4): 394-6.

Massuda ET \& Oliveira JAA. Avaliação do biosilicato como prótese de orelha média. Tese de Doutoramento, Faculdade de Medicina de Ribeirão Preto, Universidade de São Paulo, 2007. pp.62.

Migliori ME. Enucleation versus evisceration. Curr Opin Ophthalmol .2002; 13 (5): 298-302.

Moura J, Teixeira LN, Ravagnani C, Peitl O et al. In vitro osteogenesis on a highly bioactive glass-ceraminc (Biossilicate ${ }^{\circledR}$ ).: J Biomed Mater Res, 2007. Disponível em: www.interscience.willey.com

Mules PH. Evisceration of the globe with artificial vitreous: 1884-1895. Adv Ophthalmic Plast Reconstr Surg .1990; 8 69-72.

Oonishi H, Kushitani S, Yasukawa E, Iwaki H, Hench LL, Wilson J et al. Particulate bioglass compared with hydroxyapatite as a bone graft substitute. Clin Orthop Relat Res .1997;(334): 316-25. 
Peitl O, Zanotto ED, Hench LL. Highly bioactive P2O5 - CaO - SiO2 Glass ceramics. J of Non-Crystalline Solids .2001a;01-12.

Pereira EJ. Determinação da atividade colágenolítica do tecido cardíaco em ratos recém nascidos e jovens. Dissertação de Mestrado, Faculdade de medicina de Botucatu, Universidade Estadual Paulista, 2001. pp.81.

Perry AC. Integrated orbital implants. Adv Ophthalmic Plast Reconstr Surg .1990; 8 7581.

Perry JD, Goldberg RA, McCann JD, Shorr N, Engstrom R, Tong J. Bovine hydroxyapatite orbital implant: a preliminary report. Ophthal Plast Reconstr Surg .2002; 18 (4): $268-74$.

Perry JD, Lewis CD, Levine M. Evisceration after complete evaluation an acceptable option. Arch Ophthalmol .2009; 127 (9): 1227-8.

Pigossi N, Raia A, Lex A, Gama AH, Simonsen O, Haddad J et al. Estudo experimental e clínico sobre o emprego, como implante, da dura-mater homógena conservada em glicerina e temperatura ambiente. Rev Assoc Med Bras .1971; 17 263-78.

Ranzani JJ, Rahal SC, Schellini SA, Marques ME, Taga EM. Repair of the anophthalmic cavity of rats with synthetic hydroxyapatite. Braz J Med Biol Res .1997; 30 (10): 1181-6.

Rodrigues AC, Schellini SA, Moraes-Silva MRB, Padovani CR. Fatores relacionados a extrusão do implante de cavidade. Rev Bras Oftlamol .1997; 56 259-64.

Roriz VM \& Panzeri H. Avaliação clínica, histológica e morfométrica de alvéolos dentários de cães preenchidos com biovidro ou biossilicato, que posteriormente receberam implantes ossointegráveis. Tese de Doutoramento, Faculdade de Odontologia de Ribeirão Preto, Universidade de São Paulo, 2006. pp.104.

Schellini SA, Hoyama E, Padovani CR, Ferreira VLR, Roça R. Complicações com uso de esferas não integráveis e integráveis na recontrução da cavidade anoftálmica. Arq Bras Oftalmol .2000; 63 (3): 175-8.

Schellini SA, Ichida FK, Padovani CR. [Anophthalmic cavity and implant extrusion]. Arq Bras Oftalmol .2007; 70 (5): 752-5. 
Schellini SA, Marques ME, Padovani CR, Taga EM, Rossa R. Comparison of synthetic hydroxyapatite and porous polyethylene implants in eviscerated rabbit eyes. Ophthal Plast Reconstr Surg .2003; 19 (2): 136-9.

Schellini SA, Zimmermann GP, Hoyama E, Pellizon CH, Padovani CR, Selva D. Polyethylene gel in the subcutaneous tissue of rats: histopathologic and systemic evaluation. Orbit .2008; 27 (3): 153-6.

Sekundo W , Seifert P. Hydroxyapatite orbital implant. A light- and electronmicroscopic and immunohistochemical study. Ophthalmology .1998; 105 (3): 539-43.

Shiratori CA, Schellini SA, Yamashita S, Padovani CR, Rossa R. [Rabbit orbital measure evaluations after enucleation and evisceration]. Arq Bras Oftalmol .2005; 68 (2): 235-9.

Silveira M. Preparo de amostras biológicas para microscopia eletrônica de varredura. In: Haddad A, Sesso A, Attias M, Farina M, Meirelles MN, Benchimol M, Soares M, Barth OM, Machado RD, Souto-PAdrón T, Souza W. Técnicas básicas de microscopia eletônica aplicadas às ciências biológicas. Rio de Janeiro: Wanderley de Souza, 1998. p. 33-7.

Sires BS, Holds JB, Archer CR. Postimplantation density changes in coralline hydroxyapatite orbital implants. Ophthal Plast Reconstr Surg .1998; 14 (5): 318-22.

Su GW , Yen MT. Current trends in managing the anophthalmic socket after primary enucleation and evisceration. Ophthal Plast Reconstr Surg .2004; 20 (4): 274-80.

Tirapelli C \& Panzeri H. Avaliação da eficácia de um biomaterial e conhecidos agentes dessensibilizantes no tratamento da hipersensibilidade dentinária- estudo in vitro e in vivo. Tese de Doutoramento, Faculdade de Odontologia de Ribeirão Preto, Universidade de São Paulo, 2007. pp.96.

Tonkelaar Id, Henkes HE, Leersum Gk. A short history of the artificial eye. Documenta Ophthalmologica .1991; 77 349-54.

Turner PV, Baar M, Olfert ED. Laboratory animal medicine - needs and opportunities for Canadian veterinarians. Can Vet J .2009; 50 (3): 257-60.

Turren CL, Figueiredo ARP, Oréfice RL, Maciel PE, Silveira MES, Gonçalves SP et al. O uso de implantes de compósito bioativo de biocerâmica em matriz polimérica na 
reconstrução do complexo zigomático orbitário: novas perspectivas em biomateriais. Arq Bras Oftalmol.2008; 71 (2): 153-61.

Yamada S, Ito T, Tamura T, Shiomi M. Age-related changes in serum/plasma biochemical parameters of WHHLMI rabbits. Exp Anim .2004; 53 (2): 159-63.

Yamamuro T, Shikata J, Okumura H, Kitsugi T, Kakutani Y, Matsui $\mathrm{T}$ et al. Replacement of the lumbar vertebrae of sheep with ceramic prostheses. J Bone Joint Surg Br .1990; 72 (5): 889-93. 


\section{APÊNDICE}

\section{Comitê de ética}

\section{unesp $\rho^{\text {Und }}$ Universidade Estadual Paulista Faculdade de Medicina de Botucatu}

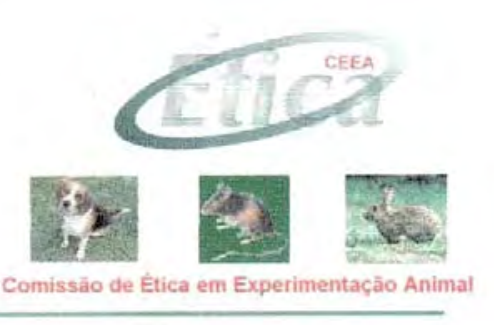

\section{CERTIFICADO}

CERTIFICAMOS que o Protocolo $n .^{\circ} 682$ sobre o projeto de pesquisa "Análise da biocompatibilidade de cones biovidro e biovitrocerâmico em cavidade eviscerada de coelho", a ser conduzido por Simone Milani Brandão, orientada pela Prof ${ }^{a}$ Dra Silvana Artiolli Schellini, está de acordo com os Princípios Éticos na Experimentação Animal adotado pelo Colégio Brasileiro de Experimentação Animal (COBEA) com a ressalva que os "coelhos" são provenientes de Biotério convencional, sem condições de certificar a sanidade dos mesmos.

Projeto de Pesquisa Aprovado em 26 de junho de 2008
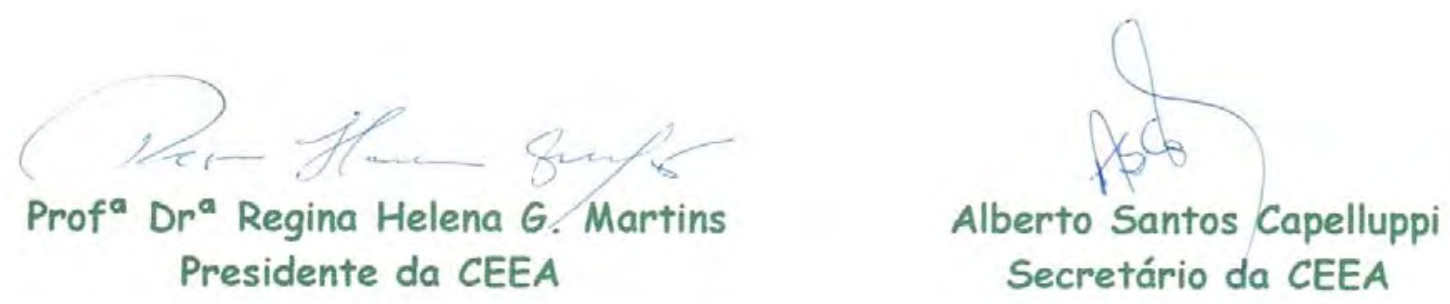